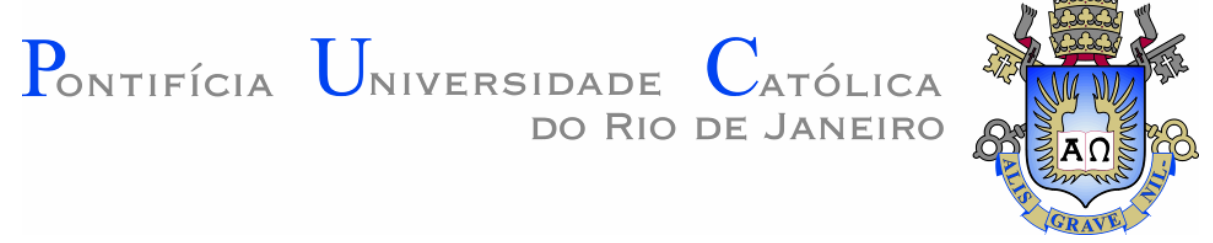

ISABELA Fleury da Rocha de CARVALHO

\title{
A INCORPORAÇÃO DE UM MODISMO ESPORTIVO À IDENTIDADE, ATRAVÉS DE MÍDIAS SOCIAIS
}

\section{DissertaÇÃo de Mestrado}

Dissertação apresentada ao Programa de PósGraduação em Administração de Empresas da PUC-Rio, como requisito parcial para obtenção do grau de Mestre em Administração de Empresas.

Orientador: Prof. Luiz Fernando Hor-Meyll 


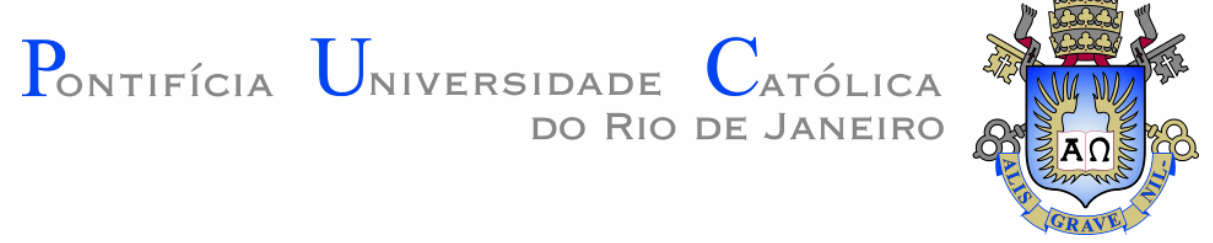

Isabela Fleury da Rocha de Carvalho

\section{A INCORPORAÇÃO DE UM MODISMO ESPORTIVO À IDENTIDADE, ATRAVÉS DE \\ MÍDIAS SOCIAIS}

Dissertação apresentada como requisito parcial para obtenção do grau de Mestre pelo Programa de Pósgraduação em Administração de Empresas da PUC-Rio. Aprovada pela Comissão Examinadora abaixo assinada.

Prof. Luis Fernando Hor-Meyll Alvares Orientador

Departamento de Administração - PUC-Rio

Prof. Marcus Wilcox Hemais Departamento de Administração - PUC-Rio

Profa. Cecília Lima de Queirós Mattoso

UNESA

Prof. Augusto Cesar Pinheiro da Silva Coordenador Setorial do Centro de Ciências Sociais - PUC-Rio

Rio de Janeiro, 27 de agosto de 2018 
Todos os direitos reservados. É proibida a reprodução total ou parcial do trabalho sem autorização da universidade, do autor e dos orientadores.

\section{Isabela Fleury da Rocha de Carvalho}

Graduou-se em Comunicação Social com habilitação em Publicidade e Propaganda pela Pontifícia Universidade Católica do Rio de Janeiro em 2011. Especializada em Gestão Empresarial e Marketing pela ESPM (Escola Superior de Propaganda e Marketing). É Analista de Marketing na empresa Lenny Niemeyer.

Ficha Catalográfica

Carvalho, Isabela Fleury da Rocha de

A incorporação de um modismo esportivo à identidade, através de mídias sociais / Isabela Fleury da Rocha de Carvalho; orientador: Luis Fernando Hor-Meyll. $-2018$.

108 f. : il. ; $30 \mathrm{~cm}$

Dissertação (mestrado)-Pontifícia Universidade Católica do Rio de Janeiro, Departamento de Administração, 2018.

Inclui bibliografia

1. Administração - Teses. 2. Marketing. 3. Comportamento do consumidor. 4. Modismo. 5. Identidade social. I. Hor-Meyll, Luis Fernando. II. Pontifícia Universidade Católica do Rio de Janeiro. Departamento de Administração. III. Título. 


\section{Agradecimentos}

Primeiramente, eu gostaria de agradecer ao meu orientador e professor Luiz Fernando Hor-Meyll por toda a paciência, compreensão e confiança depositadas em mim durante todo este período. Sem ele, chegar aqui não teria sido possível.

À professora Ana Raquel Rocha, pelo apoio e instruções que foram essenciais para o início do tema desta dissertação.

À CAPES e à PUC-Rio, pelos auxílios concedidos, sem os quais este trabalho não poderia ter sido realizado. O Presente trabalho foi realizado com o apoio da Coordenação de Aperfeiçoamento de Pessoal de Nível Superior - Brasil (CAPES) - Código de Financiamento 001.

Ao Bruno Castello Memoria, mestre em Administração pela PUC-Rio, por ter me indicado e me encorajado muito a realizar o curso, contribuindo também com meus estudos preparatórios.

Em especial, um agradecimento ao meu colega, amigo e companheiro Luiz Guilherme Pereira, presente que o mestrado me proporcionou, e que me acompanhou em toda essa dura jornada de dois anos - e continua do meu lado, sempre e pra sempre.

Agradeço ao meu pai, Carlos Alberto Baptista de Carvalho, por toda a força moral e psicológica para que eu não desistisse deste sonho. À minha mãe, Maria Tereza Fleury, que se prontificou, sempre que necessário, a me ouvir e contribuir com o 
que fosse preciso, da forma que fosse preciso. À minha avó linda, Therezinha Baptista, que mesmo sobre dificuldades, nunca deixou de se preocupar comigo e perguntar sobre o andamento do curso.

E por último, eu gostaria de agradecer à própria PUC-RIO, que através do Mestrado Acadêmico de Administração de Empresas me proporcionou momentos únicos de aprendizado, compartilhamento de ideias, troca e criação de conteúdo, além de aulas descontraídas e dinâmicas com professores de excelente conhecimento e formação profissional. Uma oportunidade incrível e inesquecível. A esta Universidade que eu amo, em que me graduei em 2012 e agora pós-graduei, meu muito obrigada! 


\section{Resumo}

Carvalho, Isabela Fleury da Rocha; Alvares, Luis Fernando Hor-Meyll. A incorporação de um modismo esportivo à identidade, através de mídias sociais. Rio de Janeiro, 2018. 108p. Dissertação de Mestrado - Departamento de Administração, Pontifícia Universidade Católica do Rio de Janeiro.

Esta dissertação procura identificar razões para a possível incorporação de um modismo esportivo à identidade social do consumidor, a partir de sua exposição nas redes sociais a postagens de conteúdo e imagens referentes a um esporte, no caso o Crossfit. Foram conduzidas entrevistas, com duração média de 40 minutos, com 10 mulheres praticantes do esporte e idades entre 18 e 39 anos. Os dados coletados foram tratados qualitativamente por meio de análise de conteúdo latente, de cunho interpretativo. Foram desvendadas evidências de que modismo é o principal ponto de partida para a prática do Crossfit, com indícios claros de incorporação do modismo à identidade social, a partir da incorporação de conceitos do esporte à vida individual e social do praticante, desde a forma de vestir até mudanças de comportamentos, como alterações nos hábitos alimentares, na autoconfiança e na autoestima e migração para novos grupos sociais, mais adequados à nova identidade. As razões declaradas pelos entrevistados para a incorporação do modismo vão desde sensações idealísticas, absorvidas durante a exposição e a observação de fotografias postadas em redes sociais, relacionadas a um esporte desafiador e motivador de superação, até sua identificação com características do praticante que exibiu suas fotografias e comentários em rede social.

\section{Palavras-Chave}

Comportamento do consumidor; modismo; identidade social. 


\section{Abstract}

Carvalho, Isabela Fleury da Rocha; Alvares, Luis Fernando Hor-Meyll (Advisor). The incorporation of a sport fad to the identity, through social media. Rio de Janeiro, 2018. 108p. Dissertação de Mestrado - Departamento de Administração, Pontifícia Universidade Católica do Rio de Janeiro.

This thesis aims to evaluate the reasons for the incorporation of a sport fad to the identity, from the exposure on social networks to postings of content and images related to a particular sport, in this case Crossfit. To achieve this goal, 40-minute individual interviews were performed with 10 women between 18 and 39 years old, all of them Crossfit practitioners. The data collected were qualitative analyzed, through content analysis, of an interpretative nature. As a result, it was concluded that faddism is the main starting point for the practice of Crossfit. Clear evidences of incorporation of this faddism to the identity were found, like the absorption of the sport concepts to the individual and social life, from the way of dressing to behavioral changes, such as in eating habits, self-confidence, self-esteem and the migration to new social groups. The reasons declared by the interviewers for this faddism incorporation range from idealistic sensations, absorbed during the exposure and observation of photos posted on the social medias, related to a challenging and overcoming motivation sport, to the identification with personal characteristics of the user's practitioner identity, exhibited on pictures and through comments in social networking sites.

\section{Keywords}

Consumer behaviour; fad; social identity. 


\section{Sumário}

1 INTRODUÇÃO 12

1.1 O Problema 12

$\begin{array}{ll}1.2 \text { Objetivo } & 15\end{array}$

$\begin{array}{ll}1.3 \text { Relevância do Estudo } & 15\end{array}$

$\begin{array}{ll}1.4 \text { Delimitaçao do Estudo } & 17\end{array}$

2 REVISÃO DE LITERATURA 19

$\begin{array}{ll}2.1 \text { Identidade } & 19\end{array}$

2.1.1 Extensão do Self 21

2.1 .2 Identidade Social 23

2.2 Identidade, Mídias Digitais e a Extensão do Self 24

2.2.1 As Mídias Digitais e a Exposição da Identidade 24

2.2.2 As Mídias Digitais e a Nova Extensão do Self 25

2.2.2.1 Desmaterialização 26

2.2.2.2 Reembodiment 27

2.2.2.3 Compartilhamento e Construção Compartilhada do Self 27

2.2.2.4 Memória Distribuída 28

2.3 A Extensão do Self nas Mídias Sociais 29

2.3.1 Mídias Sociais $\quad 29$

2.3.1.1 A Auto Apresentação e o Compartilhamento de Fotos nas Mídias Sociais 33

2.3.1.1.1 O Compartilhamento de Fotos no Instagram 35

2.4 A Imagem do Corpo nas Mídias Sociais 36

2.4.1 O Modismo como Influência 36

2.4.1.1 Tribos 38

2.4.2 A Aparência Física que Constrói a Identidade 39

2.4.2.1 A Prática do Esporte, o Branded Fitness no Crossfit e a Busca pelo Aprimoramento do Self $\quad 40$

2.4.2.2 A Aparência Física Através do Esporte 43

2.4.2.2.1 A Importância do Corpo nas Mídias Sociais 44 
2.5 O Crossfit no Mundo 45

2.5.1 O Crossfit no Brasil 47

2.5.2 O Crossfit e a Imagem do Corpo 47

2.5.2.1 O Crossfit e a Construção de Identidade 48

2.5.2.2 O Crossfit e o Compartilhamento de Fotos 49

3 MÉTODO 50

3.1 Coleta de Dados 51

3.1.1 Entrevistas 52

3.1.1.1 Seleção de Entrevistados - Pré Entrevistas 52

3.1.1.2 Entrevistas Fenomenológicas 53

3.2 Tratamento dos Dados 55

3.2.1 Pré Análise 56

3.2.2 Exploração do Material 56

3.2.3 Tratamento dos Relatos e Discussão 57

3.3 Limitações do Método 59

4 APRESENTAÇÃO E ANÁLISE DOS RESULTADOS 61

$\begin{array}{lll}\text { 4.1 Análise do Conteúdo das Entrevistas } & 61\end{array}$

4.2 Categorias de Análise 62

4.2.1 Categorias Iniciais 62

4.2.1.1 Visualização de Muitos Praticantes 63

4.2.1.2 A Força da Divulgação Online 64

4.2.1.3 O Boom do Crossfit 64

4.2.1.4 O Esporte da Moda 65

4.2.1.5 Amigos e Comentários Positivos 66

4.2.1.6 Quantidade de Amigos que Praticam o Esporte 67

$\begin{array}{ll}\text { 4.2.1.7 Sensação de Pertencimento } & 67\end{array}$

4.2.1.8 Identificação de Trejeitos, Gírias e Roupas 68

4.2.1.9 Comparação com Midiáticos $\quad 69$

4.2.1.10 Ilusão Física e Autoestima 69

4.2.1.11 Mudança Corporal e Autoestima 70

4.2.1.12 Esporte, Comportamento e Fitness 71

4.2.1.13 Comunicação e Integração 72 
4.2.1.14 Amizades do Esporte $\quad 72$

$\begin{array}{lll}\text { 4.2.1.15 Autoestima e Exibicionismo } & 73\end{array}$

4.2.1.16 Fotos, Inovação e Superação de Metas 74

4.2.1.17 Autoconfiança e Tarefas Pessoais 75

4.2.1.18 Auto Desafio e Superação 76

4.2.2 Categorias Intermediárias 76

4.2.2.1 Disseminação e Divulgação Online 77

4.2.2.2 Crescimento Desenfreado 78

4.2.2.3 Incentivo de Amigos 79

4.2.2.4 Identidade 80

4.2.2.5 Socialização e Comunicabilidade 82

4.2.2.6 Exibicionismo 82

4.2.2.7 Autoconfiança 84

4.2.3 Categorias Finais 85

4.2.3.1 Modismo 85

4.2.3.2 Identidade Social 86

4.2.3.3 Mídias Sociais, Exibicionismo e Autoestima 88

5 CONCLUSÕES 90

5.1 Discussão dos Resultados Obtidos 90

5.2 Aplicações Gerenciais 92

$\begin{array}{ll}5.3 \text { Sugestões para Novas Pesquisas } & 93\end{array}$

6 Referências bibliográficas $\quad 94$ 


\section{Lista de Tabelas}

Tabela 1 - Classificação de mídia social por presença social/riqueza de mídia e auto apresentação/auto divulgação

Tabela 2 - Perfil das entrevistadas

Tabela 3 - Categorias de Análise

Tabela 4 - Formação da categoria intermediária "Disseminação e divulgação online"

Tabela 5 - Formação da categoria intermediária "Crescimento desenfreado"

Tabela 6 - Formação da categoria intermediária "Incentivo de amigos" 79

Tabela 7 - Formação da categoria intermediária "Identidade"

Tabela 8 - Formação da categoria intermediária "Socialização e comunicabilidade"

Tabela 9 - Formação da categoria intermediária "Exibicionismo"

Tabela 10 - Formação da categoria intermediária "Autoconfiança"

Tabela 11 - Formação da categoria final "Modismo"

Tabela 12 - Formação da categoria final "Identidade social"

Tabela 13 - Formação da categoria final "Mídias sociais, exibicionismo e autoestima"

\section{Lista de Figuras}

Figura 1 - Interfaces do Instagram. (a) Página principal, (b) Utilização de Filtros 1, (c) Utilização de Filtros 2

Figura 2 - Proporção de Categorias

Figura 3 - Desenvolvimento de análise de conteúdo 


\section{Introdução}

\section{1}

\section{O Problema}

A palavra identidade, em português, surgiu a partir do latim identitas, derivada da expressão idem et idem, um intensificador para "idem" ou "a mesma coisa", trazendo a ideia de semelhança, igualdade, ainda que objetos de estudos distintos (VILHENA, 2014). Também associada à consciência que um indivíduo tem de si próprio, e que o torna um ser diferenciado dentro de um contexto coletivo, a identidade pode, e quase sempre é, influenciada pelo meio no qual está envolvida (PADILHA; CABRAL, 2015)

O termo, muito utilizado na Psicologia, em outras áreas do conhecimento e, de forma mais atual, em Marketing, é geralmente atrelado a características e traços próprios de um indivíduo ou de uma comunidade (MARQUES, 2016). Segundo Marques (2016), a ideia está associada a algo próprio de cada um, muitas vezes disfarçada e encoberta por atitudes e comportamentos ocasionais, não necessariamente reais e identitários do indivíduo.

Em busca de um termo mais especifico, é provável que já se tenha ouvido falar em self, que muitos confundem com identidade. Self é aquilo que define o ser humano na sua individualidade e subjetividade, sua verdadeira essência, imagem de si mesmo. O termo foi inicialmente utilizado por psicanalistas ingleses para designar a pessoa como "lugar de atividade psíquica, ou seja, o self seria o produto de processos dinâmicos que asseguram a unidade e a totalidade do sujeito" (MARQUES, 2016).

A palavra self, se traduzida para o Português, pode ser chamada de "si" ou de "eu", mas nenhuma das duas traduz de forma correta, tanto que são pouco usadas por estudiosos. Com a intenção de seguir da forma correta, serão utilizadas as palavras "identidade" e "self" ao longo da dissertação, a fim de referenciar, respectivamente, às características próprias do indivíduo, e ao "eu” interior de cada um (MACEDO; SILVEIRA, 2012). 
Há diversas formas e inúmeros contextos para se estudar a identidade e o self, mas aqui os termos serão atrelados à construção da identidade e à extensão do self através da visão do Marketing, com referências e definições provenientes tanto de estudos do comportamento do consumidor, quanto de estudos de psicologia, estes voltados para comportamentos dos indivíduos como pessoas únicas, fora das circunstâncias do mundo mercadológico.

Com o objetivo de compreender melhor o comportamento do consumidor e a extensão do self na atualidade, a dissertação tem a proposta de complementar os estudos já realizados até o momento e, também, do consumo e das posses como fatores principais da criação da identidade e do self do consumidor.

Com a globalização e o surgimento e avanço das mídias digitais, muita coisa mudou na vida das pessoas e na construção do self e das identidades, ao ponto que estudos mostram que indivíduos buscam recriar dentro do mundo online, suas identidades próprias do mundo offline (BULLINGHAM; VASCONCELOS, 2013). Vale, portanto, adquirir maior conhecimento acerca destes avanços midiáticos e suas influências em direção contrária, do mundo online para o offline, e coletar mais informações que direcionem a busca por outros motivos que visam a formação da identidade e do self do consumidor offline.

Em 1990, a internet surgiu como a maior novidade do mercado. Ninguém jamais teria imaginado a importância que esse lançamento significaria para as pessoas e para o mundo (KLEINA, 2011). Os anos passam e cada vez mais pessoas se conectam e permanecem conectadas o dia todo (KLEINA, 2011). Estudo de PadillaWalker et al. (2010) revelou que jovens adultos gastavam cerca de 3 horas e meia por dia na internet - a maior parte do tempo em e-mails, entretenimento e escola/trabalho.

O Facebook lançou um relatório (WU et al., 2015) com análise do estado de conectividade global de 2015 e avanços e mudanças ocorridos desde 2014. No final de 2015, estimativas apontavam que 3.2 bilhões de pessoas já estavam conectadas (online), ou seja, $43 \%$ da população mundial da época, mostrando que nos 10 anos anteriores houve crescimento de 200 a 300 milhões por ano.

Informações mais atuais retiradas do site WeAreSocial revelaram que usuários entre 16 e 64 anos, em países em desenvolvimento como Filipinas, Brasil, México e Argentina, gastam, em média, 8 horas por dia na internet, uma combinação de 
conexões móveis mais rápidas e melhores acessos a smartphones (KEMP, 2017). Segundo pesquisa de março de $2017,49.7 \%$ da população mundial tem acesso à internet, contra $43 \%$ em 2015, indicando um crescimento de $936.0 \%$ desde o ano de 2000 (ARGAEZ, 2017). Destes quase 50\% com acesso à internet, 37\% são usuários ativos de mídias sociais (CHAFFEY, 2017)

Cada vez mais, diferentes plataformas são utilizadas para criar, compartilhar e discutir conteúdos online, dentre elas sites de compartilhamento, blogs, redes sociais e wikis (KIETZMANN et al., 2011). Quando se trata de mídias sociais, o crescimento na utilização dos smartphones fez com que estes se tornassem a forma mais comum de acesso às plataformas, com $66 \%$ de usuários afirmando que usam seus aparelhos para verificar suas contas online (LUNDEN, 2014).

Seguindo este panorama de crescimento da internet e do uso de smartphones, as mídias sociais se tornaram a preferência de entretenimento online dos consumidores (KAPLAN; HAENLEIN, 2010). No segundo trimestre do ano de 2008, 75\% dos usuários de internet já navegavam em mídias sociais, um crescimento de $56 \%$ se comparado ao ano de 2007, enquanto em janeiro de 2009, Facebook registrava mais de 175 milhões de usuários ativos e o Youtube já continha 10 horas de conteúdo publicado a cada minuto (KAPLAN; HAENLEIN, 2010). Em 2010, o Twitter já atingia a marca de mais de 145 milhões de usuários ativos trocando, em média, 90 milhões de "tweets" por dia (MADWAY, 2010), enquanto já em 2017, com um crescimento de $6 \%$ ao ano, o twitter atingiu 328 milhões de usuários (MOON; SADAM, 2017).

Apesar do Facebook ainda ser a rede social dominante no mercado, o Instagram se destaca com um crescimento mais rápido já registrado, passando de 100 milhões de usuários no primeiro trimestre de 2013 para mais de 500 milhões no segundo trimestre de 2016 (RICHTER, 2017), atingindo 700 milhões em 2017 (SATURNO, 2017). O Instagram se mantém em segundo lugar com um engajamento de quase 65\% de usuários entre 18 e 34 anos, uma média de acesso por pessoa de 300 minutos/mês (ALLEN, 2017) e ainda, log in diário de 51\% de seus usuários (CHAFFEY, 2017).

No Brasil, dos 66\% (139.1 milhões) de usuários de internet, 58\% (122 milhões) frequentam sites de mídias sociais (CHAFFEY, 2017), sendo que mais de 45 milhões de brasileiros (aproximadamente 37\%) utilizam o Instagram todo mês, 
com uma base de usuários em crescimento de 1 milhão/mês, em média (TOZETTO, 2017). Os maiores atrativos atuais da rede, além das fotos publicadas, são o stories - em que o usuário pode postar vídeos e fotos que permanecem ativos para seus seguidores por $24 \mathrm{~h}$ - e a nova função direct - que permite ao usuário trocar imagens e vídeos privados entre perfis (SATURNO, 2017).

Ao mesmo tempo em que o Instagram se tornou uma das redes sociais com maior crescimento no Brasil, de 2010 a 2015 o segmento fitness passou de $\mathrm{R} \$ 16,2$ bilhões para $\mathrm{R} \$ 23,3$ bilhões, ainda com previsão de chegar a $\mathrm{R} \$ 27,6$ bilhões em 2020 (AUDREI, 2016). Com esse aumento pela procura de uma vida mais saudável, alguns esportes têm sobressaído mais: o Crossfit, atividade muito comum nos Estados Unidos e marca registrada pelo ex-ginasta americano Greg Glassman desde 1995 (HERZ, 2014), chegou ao Brasil e, especialmente, ao Rio de Janeiro. O esporte mistura ginástica olímpica, treinamento funcional e levantamento de peso e, hoje, há em média 50 mil praticantes e quase mil espaços disponíveis para a prática em todo o Brasil. Só no Rio, há mais de 70 espaços para treino (KNOPLOCH; FURTADO, 2017).

Através da realização desta dissertação, esse estudo pretende responder a seguinte questão de pesquisa: quais são algumas das possíveis razões que levam o consumidor a incorporar um modismo esportivo à identidade, a partir da exposição às imagens de determinadas atividades esportivas divulgadas nas mídias sociais?

\section{2 \\ Objetivo}

Identificar razões que influenciam consumidores de redes sociais a incorporar um modismo esportivo às suas identidades, através da exposição às imagens nessas mídias.

\section{3 \\ Relevância do estudo}

Como citado anteriormente, o crescimento das mídias digitais e sociais se deu de forma muito rápida e continuará aumentando (KAPLAN; HAENLEIN, 2010). Só no Brasil, o investimento em mídias digitais saltará de $\mathrm{R} \$ 4$ bi em 2012 para, em média, R\$16 bi em 2020 (AUDREI, 2017). Mais impressionante ainda é o fato de 
que $56 \%$ da população brasileira está na internet, sendo que $44 \%$ dos que estão conectados também se encontram nas mídias sociais (AUDREI, 2017).

A literatura existente sustenta que a postagem e compartilhamento de conteúdo (ex: HAMBRICK; FREDERICK; SANDERSON, 2015; SANDERSON; HAMBRICK, 2012), assim como a troca e facilidade de interação nas mídias sociais (ex: EAGLEMAN, 2013; MCCARTHY et al., 2014) intensificam a comunicação, desenvolvimento da relação e a promoção de marcas e famosos.

Percebeu-se que as mídias sociais são essenciais para criar e nutrir as diferentes relações, transformando-as em um ferramental crítico para a troca mútua de informações (GRÖNROOS, 2004). Como exemplo, podemos citar as redes de usuários criadas a partir da análise dos seguidores de mídias sociais de determinadas marcas (CLAVIO; BURCH; FREDERICK, 2012), que sugere que as marcas mais engajadas nessas plataformas têm maior facilidade em construir e manter relações significativas junto as comunidades de consumidores (HATCH; SCHULTZ, 2010). Muitas oportunidades têm sido reconhecidas com o uso das mídias sociais como o aprimoramento de conteúdo, a interação e a criação de comunidades (MCCARTHY et al., 2014).

As vantagens das mídias sociais têm sido elucidadas através do atual corpo literário e, ainda, a melhora do conhecimento dos consumidores, a forma de interação avançada e o alto engajamento de todos reforçaram o valor proveniente da criação conjunta (BRODIE et al., 2011, 2013).

Os diferentes desafios e oportunidades referentes à prática de esportes divulgadas nas mídias sociais têm aumentado significativamente as pesquisas acadêmicas na área, porém grande parte das pesquisas é meramente descritiva, limitada ao contexto das marcas e derivada da perspectiva Norte Americana (FILO; LOCK; KARG, 2015). As mídias sociais transcendem limites geográficos (SHILBURY et al., 2014), o que justifica a inclusão de uma abordagem de pesquisa além dos limites de apenas uma região, a fim de avaliar os impactos de fatores culturais no uso destas mídias (FILO; LOCK; KARG, 2015). Há, portanto, relevância em acrescentar novos conhecimentos sobre o comportamento dos consumidores destas mídias - e em diferentes mídias - em múltiplos contextos e países, visto que estas pesquisas proporcionam insights aos acadêmicos de gestão esportiva em como otimizar o uso das mídias sociais do ponto de vista estratégico e operacional (FILO; LOCK; 
KARG, 2015). Há diferentes estudos sobre o Twitter, Facebook, e outras plataformas de mídias sociais falando sobre a utilização da imagem e dos perfis como forma de criação e extensão de identidades (ex: SORAPURE, 2003; BACK et al., 2010; TOSUN, 2012) e, não menos importante, o Instagram também merece grande atenção (HU; MANIKONDA; KAMBHAMPATI, 2014), já que seu crescimento tem sido muito rápido, principalmente no Brasil (TOZETTO, 2017).

Ainda, podemos notar uma lacuna importante no campo de marketing quando se trata do estudo da incorporação de um modismo. Apesar de ser um tópico de interesse permanente no campo do comportamento em grupo (PARK; BURGESS, 1924) e de haver algumas discussões sobre o assunto, ninguém apresentou, ainda, um estudo mais sistemático e teórico sobre ele (AGUIRRE; QUARANTELLI; MENDOZA, 1988) em relação à identidade, a partir das mídias sociais. Poucos autores debruçaram-se sobre o fenômeno, que vem crescendo de forma exponencial (COYNE; PADILLA-WALKER; HOWARD, 2013), forçando diferentes abordagens mercadológicas.

\section{4 \\ Delimitação do Estudo}

Tradicionalmente, o estudo das mídias sociais e suas definições dentro do contexto do esporte têm focado muito na distinção entre as tecnologias de web 1.0 e web 2.0 (KAPLAN; HAENLEIN, 2010). Porém, estas mídias precedem a web 2.0 (HARRISON; BARTHEL, 2009) e, portanto, excluem-se desta pesquisa análises referentes à distinção entre web 1.0 e 2.0, focando apenas em componentes de mídias sociais que se diferem de outros meios. Para tal, as definições de mídias sociais deste trabalho englobam plataformas das novas categorias de mídias, dentre elas sites de redes sociais, blogs, microblogs, comunidades online e fóruns de discussões (SHILBURY et al., 2014). Dentre as plataformas visuais e sites de redes sociais como Facebook, Twitter, Linkedin, entre outras, o Instagram tem se tornado muito popular, sendo avaliado como a plataforma de mídia social com maior crescimento no mercado (LUNDEN, 2014; RICHTER, 2017) e, portanto, esta será a plataforma base utilizada para esta pesquisa.

As variações demográficas e de gênero resultam em diferentes motivos que influenciam o uso das mídias sociais, dentre elas a interatividade, o entretenimento, 
acúmulo de informações, empatia, entre outros. Estudos focados nos usuários destas mídias ilustram que a maioria é jovem e possui educação básica, sendo a maior parte composta por homens (FILO; LOCK; KARG, 2015). Porém, foram encontrados indícios de que mulheres atletas têm mais consciência de imagem ao usar mídias sociais (BUTTS, 2008; LEBEL; DANYLCHUK, 2012), base fundamental para este estudo que fala sobre incorporação de atitudes à identidade. O modismo aqui estudado não leva em consideração se a questão da formação do hábito é racional ou míope, ou seja, se o Crossfit é um hábito saudável ou não. 


\section{2 \\ Revisão de Literatura}

\section{1 Identidade}

Muitos autores se arriscaram na desmistificação da identidade (ex: BAUMAN, 2001; BELK，1987，1989，1991; GIDDENS，1991; JAMES，1890; TAJFEL; TURNER, 1986), abrindo portas para inúmeros estudos acerca do tema, capazes de explicar - de diferentes e interessantes formas - como se dá a construção da identidade e do self de cada um. Fatores provenientes de diversas frentes influenciam nesta concepção detalhada, e paulatinamente criada, do autoconhecimento e personalidade (BAUMAN, 2001).

Para que possamos entender o comportamento dos consumidores diante de tantas mudanças e desenvolvimentos na contemporaneidade, abordaremos diversos pontos de vista, a fim de ganhar, também, um pouco de conhecimento a respeito do significado que os consumidores atribuem às suas posses.

As posses têm um papel fundamental na formação e construção dos objetivos do self de cada ser humano. Um dos primeiros a criar concepções mais modernas da identidade do self foi James (1890). O autor afirma que as pessoas são a soma de suas posses, ou seja, sentem e agem acerca de certos objetos assim como o fazem acerca de si mesmas. O senso do self de cada um é frágil e, portanto, precisa de ajuda e suporte constantes (TUAN, 1978) e, neste caso, os bens e as posses materiais adquirem valor, atuando como sinais para este self e para o mundo de significados criados para nós e que nos cria (ROCHBERG-HALTON, 1984). Os objetos externos, que estão além do nosso corpo físico, se tornam parte do self: quanto maior o controle sobre eles, maior a possibilidade do objeto se tornar parte do self (MCCLELLAND, 1951). Para que o ser humano adquira essa sensação de base e apoio, ele compra e possui objetos em busca de melhorar sua própria autoimagem (BRITT, 1966) e, muitas vezes, se cerca de pessoas, relações e sentimentos (AHUVIA, 2005), já que, diante de uma visão superficial, somos o que temos e possuímos. Estes objetos em questão atuam como ativadores de 
recordações e, portanto, confirmadores de nossas identidades, identidades estas que devem constar mais nos objetos do que nos próprios indivíduos (MCCARTHY, 1984). E é neste ponto que fica fácil a compreensão de que as posses, assim como pessoas, lugares, grupos, partes do corpo e órgãos vitais (BELK, 1988) se tornam uma extensão do self:

"o self do homem é a soma de tudo o que ele pode chamar de seu, não apenas seu corpo e seus poderes psíquicos, mas suas roupas e sua casa, sua esposa e seus filhos, seus ancestrais e seus amigos, sua reputação e trabalhos, suas terras e cavalos, iate e conta bancária. Todas essas coisas lhe proporcionam as mesmas emoções. Se ele cresce e prospera, ele se sente triunfante; se ele apequena e 'morre', ele se sente abatido, - não necessariamente com a mesma intensidade para casa situação, mas da mesma forma para todos." (JAMES, 1890, p. 291-292)

Aproveitando McCarthy (1984) e Ahuvia (2005), as emoções são parte importante através das quais as identidades são construídas, modificadas e até mesmo desconstruídas. McCarthy (1994) comenta a semelhança das emoções e das identidades, afirmando que, tanto uma como a outra são fenômenos culturais, pois só podem ser compreendidas junto dos sistemas, culturas e mundos sociais dentro das quais estão inseridas. Ainda, as emoções são sinais naturais e reais do nosso verdadeiro self, apesar de serem "embaladas" e "consumidas" junto e diante dos produtos disponíveis no mercado, e atuam como padrões estabelecidos do self moderno em um mundo constantemente fabricado (MCCARTHY, 2002).

Há uma interdependência cíclica e cruzada entre humanos e objetos (HODDER, 2012). Os homens dependem dos objetos para mostrar aquilo que podem fazer e os objetos dependem dos humanos para que existam; não raro, humanos dependem de outros humanos para que possam viver em "paz e produtividade" e os objetos dependem de outros objetos para que possam "coexistir" entre si, ou seja, fundindo suas funções (exemplo: o carro e o computador) (HODDER, 2012).

Após a compreensão de como as identidades e o self de cada indivíduo são formados e construídos ao longo de suas vidas, podemos ampliar o leque de informações até aqui apresentadas para falarmos da extensão do self e da identidade social. 


\title{
2.1.1 \\ Extensão do Self
}

De modo simbólico, as posses podem se tornar uma extensão de nós, projetando para além de nossas mentes e corpos físicos, de certa forma, nosso inner self (tradução literal: “eu interior”). Belk (1988), ainda, exemplifica:

\begin{abstract}
“(...) quando um uniforme ou um troféu permitem que nos convençamos (e talvez a outros) que podemos ser pessoas diferentes do que seríamos se não os possuíssemos. (...) Então, possuir bens pode contribuir pra nossas capacidades de fazer e ser. As relações entre ter, fazer e ser são fortes (...).” (p. 145).
\end{abstract}

Os indivíduos agem em relação a alguma coisa devido a manifestação mais profunda dos seus desejos de ter ou ser, e a razão pela qual se busca ter e possuir alguma coisa está na vontade das pessoas de expandir este self de alguma forma, pois o único jeito de saber quem somos é observando o que temos (SARTRE, 2005).

Aron e Aron (1986) propuseram, inicialmente, que as pessoas próximas às outras dentre elas mãe, pai e outros amigos próximos - também podem ser vistas como parte da identidade e do self dos indivíduos, já que tendem a criar fortes laços e os aspectos da vida do outro acabam por se fundir com os seus, e essas, antes, individualidades, passam a se confundir com a personalidade dos dois seres (ARON et al., 1991).

Outra forma de extensão do self está de acordo com a pesquisa de percepção do self (MCCLELLAND, 1951), em que as partes do corpo humano também são elementos centrais da extensão do self e, assim como energias emocionais do indivíduo podem ser carregadas em objetos, atividades e ideias, as mulheres tendem a alocar muitas emoções nas próprias partes de seus corpos, refletindo uma auto aceitação (ROOK, 1985).

Com base no fato de que as identidades e o self são criados e construídos através do consumo e das posses de bens materiais, não materiais e relacionamentos, e que a extensão deste self se dá através desses construtos (BELK, 1988; ROCHBERGHALTON, 1984; SARTRE, 2005; THOMPSON; HIRSCHMAN, 1995), dar/doar bens e posses para terceiros também é uma forma de estender o próprio self - uma forma especial de controle, visto que um presente sempre ficará associado à 
identidade do doador, criando uma extensão dessa identidade de maneira a incluir o destinatário (SARTRE, 2005).

O modo de ser e o caráter pessoal - depois de dotados de significados socialmente construídos através de bens e relacionamentos, e transmitidos em uma determinada sociedade - se transformam em gostos, tornando-se estilos de vida incorporados pelos indivíduos (BELK, 1988). Apesar de haver uma hierarquia nos níveis do self de cada um, já que em cada situação - seja ela como indivíduo ou como uma pessoa inserida em um ambiente coletivo - as pessoas agem da forma mais apropriada para aquele momento especifico, o core self, digamos o "eu central", mantém ao seu redor as posses centrais (BELK, 1988). Essas posses podem claramente diferir em relação aos indivíduos, de acordo com o tempo e em diferentes culturas, já que estas criam significados diversos e simbólicos para os bens, para serem compartilhados em comum (BELK, 1988).

Objetos podem possuir significados particulares, mas também compartilhados, quando inseridos em uma cultura (BELK, 1987). Objetos de consumo com significados compartilhados - dentre eles marcas, lugares, monumentos públicos podem envolver certa apropriação mental, apesar de serem vistos como "objetos comunitários", utilizado por terceiros (BELK, 1987). Porém, segundo Belk (1987), é importante citarmos os objetos de mercado (ex: carros, shampoos, violão, etc), vendidos em lojas disponíveis à todos, pois apesar de estarem, de certa forma, acessíveis, podem ser adquiridos e utilizados individualmente por um preço. As empresas tentam dotar estes objetos de mercado com significados particulares e compartilhados, mas uma vez adquiridos, estes bens se tornam particulares com significados pessoais (BELK, 1987).

Belk (1988) deixa clara essa relação entre o que os indivíduos consomem e os reflexos deste consumo em suas identidades. A extensão do "eu" ('extended self') se dá através da posse e demonstração destes diferentes símbolos, influenciando na construção de uma identidade, o que faz com que as pessoas tenham papeis e personalidades específicos dentro das hierarquias sociais. "Nós existimos não apenas como indivíduos, mas também como coletividades" (BELK, 1988, p. 152). Com tamanhos estudos e diferentes alternativas acerca da formulação da extensão da identidade de cada um, percebe-se o enriquecimento e aprimoramento em grande magnitude das perspectivas na construção dessas relações entre pessoas e objetos 
(BELK, 2014b). Nota-se, porém, uma característica comum em todos os modelos estudados de que a extensão da identidade não termina com a mente nem o corpo, ou seja, pessoas, lugares e objetos - e isso inclui objetos virtuais - são todos parte integrante das identidades e comportamentos das pessoas (BELK, 2014b).

\subsection{2 Identidade Social}

A Teoria da Identidade Social surgiu a partir da noção de que os indivíduos se esforçam para fazer parte de categorias sociais que refletem, positivamente, seus conceitos de self (TAJFEL, 1982; TAJFEL; TURNER, 1979). Estas categorias, definidas a partir de características extraídas dos membros, podem estar divididas entre membros de uma organização, grupo religioso, gênero, idade, entre outros (TURNER, 1985). Conceito muito utilizado no Marketing Esportivo, a teoria abrange perspectivas importantes de um indivíduo como a identificação e sensação de pertencimento a um grupo e a influência do comportamento de um indivíduo em relação a outro (LOCK et al., 2012). Ela estuda como os indivíduos definem o próprio self e como eles são definidos por terceiros, dentro dos grupos sociais aos quais pertencem (TAJFEL; TURNER, 1979).

De acordo com a teoria, o autoconceito de cada um depende de duas vertentes: a identidade pessoal, dotada de características pessoais e próprias de cada um (habilidades, interesses, atributos, etc); e a identidade social, composta por classificações compartilhadas de grupo, ou seja, o indivíduo sabe de seu pertencimento a determinado grupo social e participar deste grupo traz algum valor (ASHFORTH; MAEL, 1989). Essa dupla vertente tem duas funções principais: ajuda a segmentar e ordenar o ambiente social do indivíduo, promovendo uma forma sistemática de definir os outros; e permite ao individio localizar e/ou definir a si mesmo neste ambiente social, dentro do grupo ao qual ele pertence (ASHFORTH; MAEL, 1989).

Com base nisto, Tajfel e Turner (1979) definiram três conceitos centrais da TIS. Primeiro, a fim de manter uma identidade social positiva, os individuos buscam participar de grupos com caracteristicas iguais ou até melhores do que seus autoconceitos. Segundo, esta identidade social positiva baseia-se em comparações favoráveis entre grupos em sincronia e grupos "rivais". Terceiro, quando os indivíduos pertencentes a um determinado grupo avaliam suas atitudes como 
negativas para seus auto-conceitos, eles deixarão o grupo ou o alterarão de forma positiva. Dito isto, nota-se que o elemento principal está na necessidade das pessoas de reduzirem os constrastes relacionados aos seus autoconceitos (HOGG; TERRY, 2000) e manterem uma imagem positiva a partir das categorias sociais as quais elas pertencem, lutando para melhorar a autoestima a partir de conceitos proporciondos pelos grupos (TAJFEL; TURNER, 1979).

Sabendo da importância do self estendido para cada um e de como essas extensões ocorrem através dos objetos, pessoas, culturas, lugares, entre outros, abrimos, ainda mais, as possibilidades para estudos que englobem novidades nos dias atuais. $\mathrm{O}$ fato é, como o avanço da tecnologia, o surgimento da internet e o boom de crescimento que vêm ocorrendo nas mídias sociais afetam e fazem parte dessa extensão do self?

\section{2 \\ Identidade, Mídias Digitais e a Extensão do Self}

\subsection{1}

\section{As Mídias Digitais e a Exposição da Identidade}

De acordo com Coyne, Padilla-Walker e Howard (2013), nas últimas décadas, a mídia digital tem estado cada vez mais presente na vida das pessoas. A Internet, telefones celulares, tablets, vídeo games e televisões começaram a fazer parte do cotidiano dos jovens adultos desde sua infância e na metade dos anos 90, a tecnologia começou rapidamente a se desenvolver (COYNE; PADILLAWALKER; HOWARD, 2013). Computadores se tornavam comuns nas famílias americanas e existiam 10 mil diferentes websites, surgindo a primeira conexão sem fio (COYNE; PADILLA-WALKER; HOWARD, 2013).

Para ilustrar a velocidade deste desenvolvimento, já no final dos anos 90, era possível navegar através de 36 milhões de websites, enquanto no início dos anos 2000, esse número atingiu a marca de 180 milhões (COYNE; PADILLAWALKER; HOWARD, 2013).

Com isso, o uso da tecnologia da informação teve um rápido aumento em quase todos os países do mundo, transformando a vida de milhões de pessoas que permanecem online diariamente, em todo e qualquer ambiente, seja na escola, no trabalho ou em casa (RUZGAR, 2005). 
Novas empresas como Yahoo, Amazon, Ebay e Google deram início ao crescimento exponencial de outros gigantes da internet, dentre eles Skype, Facebook, Youtube, Instagram, Twitter, entre outros (COYNE; PADILLAWALKER; HOWARD, 2013). Webpages, jogos online, ferramentas de busca, mundos virtuais, smartphones, MP3 players, câmeras digitais e outras tecnologias têm tomado conta da vida das pessoas (BELK, 2013).

Com tantas modificações tecnológicas, Sheth e Solomon (2014) identificam que o self e o "não self", o corpo e os estímulos externos, tiveram três divisões, ou talvez limites, reduzidos: online e offline, produtor e consumidor, corpo e tecnologia.

“Online, parece que nós estamos livres dos nossos corpos físicos”, disse Belk (2014a). Consumidores se sentem livres para expressar suas identidades através destas novas associações digitais, sem a proximidade física ou a necessidade de posse de um objeto (SCHAU; GILLY, 2003). Porém, tudo em excesso tem suas consequências, muitas vezes devastadoras para o ser humano. O uso patológico dessas novas mídias, principalmente games e internet, pode se tornar problemático quando utilizado de forma incorreta, prejudicando outras áreas importantes como relações pessoais, amizades, saúde e o bem-estar psicológico (GENTILE; COYNE; BRICOLO, 2013). Usuários constantes destas mídias digitais se dizem "viciados" e alegam sintomas de abstinência quando tentam reduzir, ou até mesmo parar, o uso das mesmas (GENTILE, 2009)

\subsection{2}

\section{As Mídias Digitais e a Nova Extensão do Self}

Temas e análises mais atuais sobre a formação de identidade e a extensão do self têm incluído as mídias digitais como ponto significativo na construção das identidades.

Por exemplo, Lonsdale e North (2011) apontam a música como fator comum entre os jovens adultos para construir, expressar e estender suas identidades. Tecnologias desenvolvidas como CDs, MP3 e a internet e, de forma mais recente, ipods, smartphones e serviços de música comercial - spotify, deezer, apple music, entre outros - aumentaram a quantidade de pessoas que ouvem músicas, através do acesso fácil e preço baixo. De acordo com estudos realizados por Rentfrow e Gosling (2003), as preferências musicais podem revelar muitas informações, permitindo a terceiros julgar e compreender as personalidades dos ouvintes. 
Ademais, segundo pesquisas, jovens adultos relacionam outras maneiras para a formação de suas identidades como as mídias impressas (livros, jornais e revistas), TVs e filmes (LONSDALE; NORTH, 2011).

Com tantos avanços tecnológicos atuais, as possibilidades e formas de construir identidades, incorporar novos gostos e estender o self além do nosso próprio corpo nunca foram tão grandes. Notam-se cinco principais mudanças com estes progressos: a desmaterialização, reembodiment (o ato de se projetar em outro “corpo/personagem", neste caso virtual), compartilhamento, construção compartilhada do self, memória/recordação distribuída. A antiga ideia de um core self, aqui, passa a ser uma ilusão (BELK, 2013). Nossos aparelhos digitais passam a ser "invisíveis", e se tornam partes naturais integrantes do nosso self (BELK, 2014a).

O entendimento destas cinco transformações é indispensável para que possamos, posteriormente, falar sobre a extensão do self nas mídias sociais. Portanto, brevemente falaremos sobre cada uma delas, sendo que "compartilhamento" e “construção compartilhada do self” formam um item apenas.

\subsubsection{1 \\ Desmaterialização}

A desmaterialização, como o nome já sugere, retrata o desaparecimento dos objetos como itens físicos e tangíveis. Segundo Belk (2013), agora, são fotos, vídeos, mensagens, músicas e informações vistas na tela de um dispositivo. Intocáveis, inalcançáveis, intangíveis, guardados em forma de dados, números e códigos, inexistentes até que decidamos buscar, clicar e abrir.

Essa perda da forma material e a transferência daqueles objetos, antes tangíveis, para o mundo online, acaba por permitir uma maior interação e troca de ideias entre grupos, assim como o compartilhamento do entusiasmo em relação a um assunto especifico com uma comunidade muito maior (BORN, 2011). Ou seja, uma transferência de como representamos nós mesmos, como conhecemos novas pessoas e interagimos. Siddiqui e Turley (2006) afirmam que cartas, livros, cartões e jornais também foram substituídos, e agora temos e-mails, e-books, e-cards e sites de notícias. A tecnologia trouxe diversas modificações na forma de consumo, e continua avançando mais rápido do que qualquer outra indústria (WOOD; SOLOMON, 2010). Agora se pode possuir, inclusive, objetos digitais que nunca 
existiram de forma material, como espadas e escudos mágicos adquiridos, muitas vezes com dinheiro real, em jogos online (WOOD; SOLOMON, 2010).

É interessante notar que, a partir de uma das informações retiradas dos estudos feitos por Cushing (2012), pode-se afirmar que consumidores mais jovens têm uma maior predisposição para ver as posses digitais como a extensão do self, muito provavelmente porque os mais velhos (58-67) tenham passado mais tempo de suas vidas com itens físicos.

\subsubsection{2}

\section{Reembodiment}

Assim como as posses deixaram de ter formas físicas, os corpos também perderam seus contornos, cores e sensações táteis, e não há mais diferenciação por gênero, raça ou classe, visto que todas as pessoas são relativamente iguais, sem rosto, sem corpo, virtuais (BOLTER, 1996).. Em um ambiente mais sociável da internet como jogos, mídias sociais e blogs, ocorre uma projeção do corpo real, para "corpos" virtuais como avatares, fotos e vídeos (BOLTER, 1996).

Antes da era digital, essa troca constante de corpos físicos para virtuais era impossível. Para que houvesse a possibilidade de se "vestir" com novas identidades, era preciso comprar novas roupas - ou até mesmo trocá-las com amigas (LURIE, 1981) -, acessórios, carros, cortar e pintar o cabelo ou mudar de grupo de amigos (BELK, 2013). Atualmente, com a invisibilidade física, fica muito mais fácil e seguro essa projeção e troca entre "corpos" através de diferentes avatares criados online, e abre-se, então, a porta para a experimentação (BELK, 2013).

Com isso, nota-se que a internet - e principalmente ela - permite com que as pessoas tenham múltiplas personalidades (SCHAU; GILLY, 2003). Mas apesar de todos, provavelmente, possuirmos várias personalidades, cada uma de acordo com uma ou mais situações sociais, há grandes dificuldades em manter essas múltiplas personalidades (JAMES, 1963).

\subsubsection{3}

\section{Compartilhamento e Construção Compartilhada do Self}

Compartilhar é algo muito comum hoje em dia, na era da internet. Fotos, atividades, pensamentos e gostos são apenas algumas das características de nossas 
personalidades que podem ser compartilhadas. Através das mídias, compartilhamse eventos importantes do passado, assim como narrativas completas e detalhadas do nosso self (BELK, 2013). Porém, como relembra Van Dijck (2008), muitas dessas identidades e memórias manipuladas que empoderam o indivíduo, podem, inúmeras vezes, criar uma visão idealizada de como gostaríamos de ser lembrados. Através dessas diferentes identidades criadas online, das possíveis e variadas interpretações do self, do anonimato e invisibilidade e, principalmente, da falta de uma conversa e troca de ideias "face-a-face", a vergonha é deixada de lado e pessoas mais desinibidas se encontram presentes atrás das cadeiras de seus computadores (TOSUN, 2012). Com isso, pesquisadores concluem que as pessoas ficam mais abertas à compartilharem seu self verdadeiro quando estão presentes em contextos online do que ao vivo (TOSUN, 2012). Porém, o fato de compartilharem um self verdadeiro não significa que há um core self (BELK, 2013).

Apesar de ser possível permanecer online de forma solitária, pesquisando, estudando, lendo notícias, ouvindo músicas e vendo fotos, a maior parte das pessoas socializa de alguma forma, seja através de mídias sociais, seja em chats ou jogos online (BELK, 2013). E é neste fato que está a construção de um self compartilhado. Quando postamos fotos nas redes sociais, por exemplo, estamos colocando parte de nosso self estendido disponível para que todos vejam, comentem e interpretem. Desta forma, os amigos e conhecidos acabam ajudando no processo de criação compartilhada deste self, no momento em que levamos em consideração suas opiniões (BELK, 2013).

Para arrematar, Steinfield, Ellison e Lampe (2008) afirmam que sites de redes sociais são importantes agregadores de informações e, portanto, bons para o desenvolvimento psicológico, principalmente dos adolescentes e adultos.

\subsubsection{4 \\ Memória Distribuída}

De acordo com Belk (1991), posses não digitais podem, muitas vezes, ser parte de nosso self estendido e trazem lembranças passadas quando associados a certos momentos de nossas vidas.

Atualmente, no mundo digital, encontramos novas formas de gravar e arquivar nossas lembranças como, por exemplo, em álbuns dentro dos nossos perfis construídos nas diferentes mídias sociais. Estas mídias nos ajudam a lembrar dos 
eventos, das viagens, das pessoas e das emoções vividas, assim como rever comentários antigos nas fotos e interagir com outras pessoas que participaram daqueles momentos, construindo assim uma memora compartilhada (BELK, 2013).

\section{3}

\section{A Extensão do Self nas Mídias Sociais}

\subsection{1}

\section{Mídias Sociais}

Com o boom das mídias digitais, surgiram então, as mídias sociais: grupo de aplicações de internet que surgiu com o advento das bases tecnológicas e ideológicas da plataforma Web 2.0 - criada em 2004 e padronizada para o desenvolvimento de web de ponta (O'REILLY, 2007) - que permite a criação e troca de User Generated Content (UGC - Conteúdo Gerado pelo Usuário) (KAPLAN; HAENLEIN, 2010). Usuários passaram a ter acesso às redes sociais, que os permitem conectar-se com terceiros, postar e atualizar, diariamente, informações pessoais (COLLIANDER; DAHLÉN, 2011; KAPLAN; HAENLEIN, 2010; SEIDMAN, 2014). Ainda, consumidores podem interagir com estas redes sociais durante diversos estágios do processo de consumo, dentre eles a busca de informação, tomada de decisão, aquisição, uso e descarte de produtos e serviços (FILO; LOCK; KARG, 2015). Os elementos chaves das mídias sociais são a presença social, riqueza de mídia (quantidade de informações presentes e compartilhadas), auto apresentação e auto divulgação (KAPLAN; HAENLEIN, 2010). A proliferação dessas redes contribuiu para a mudança no padrão de comunicação e interação social das pessoas (NAAMAN; BOASE; LAI, 2010).

As mídias sociais podem ser voltadas para as massas como Facebook, Instagram, YouTube, Blogs e Flickr, ou para profissionais em busca de networking como o LinkedIn (NAAMAN; BOASE; LAI, 2010).

Cada vez mais frequentes, estudos têm relacionado as mídias sociais à (re)construção da identidade e exploração do self, através da constante exposição do indivíduo a uma comunidade de amigos/conhecidos, o que explica o sucesso deste tipo de mídia (BACK et al., 2010; HUM et al., 2011). Segundo Back et al. (2010) "(mídias sociais) podem ser um meio eficiente para expressar e comunicar a personalidade real (dos usuários), o que pode ajudar a explicar sua popularidade". Esta forma de apresentação da identidade pode ocorrer através da auto divulgação 
- consciente ou inconsciente - de informações subjetivas como pensamentos, sentimentos, interesses e desinteresses (KAPLAN; HAENLEIN, 2010).

O conceito de auto apresentação é muito importante dentro das mídias sociais, pois os consumidores divulgam suas histórias, expressam suas opiniões e compartilham informações representativas de si mesmos (WU; CHANG; YUAN, 2015), com o objetivo de influenciar outras pessoas de certos comportamentos (exemplo: causar boa impressão) ou, até mesmo, pelo desejo de criar uma imagem que corresponda à identidade pessoal de alguém (exemplo: vestir uma roupa fashion para parecer jovem e na moda) (KAPLAN; HAENLEIN, 2010). Ainda, este ambiente online serve como forma de auto apresentação conspícua do self, e cada postagem é uma escolha que possui um potencial significado; e permite aos usuários esconder traços indesejados de suas identidades (SCHAU; GILLY, 2003) como gênero, idade e aparência, revelando-os apenas àqueles poucos escolhidos e selecionados. O indivíduo é responsável pelo self que ele projeta e a reflexividade deste self é contínua e mutável, visto que ele se auto interroga, constantemente, sobre como ele pode mudar naquele momento, a fim de atender às necessidades daquela exata situação (GIDDENS, 1991) - ou seja, ele é não apenas aquilo que é, mas também o que ele faz do seu self quando lhe convém.

Segundo Goffman (1956), as pessoas buscam atuar de acordo com as diferentes situações que enfrentam no dia a dia, e expressam suas identidades através de mensagens verbais e não verbais, a fim de passar uma imagem específica e atingir o próximo da forma mais confiável possível.

A tabela 1 classifica as mídias sociais ilustrando a combinação entre auto apresentação/auto divulgação e presença social/riqueza de mídia (KAPLAN; HAENLEIN, 2010). Sites de redes sociais como Facebook e Instagram que permitem, além de comunicações textuais, o compartilhamento de fotos, vídeos e outras mídias, têm um nível médio de presença social e riqueza de mídia, porém e mais importante - alto nível de auto apresentação e auto divulgação. Estes dois últimos caracterizam-se pela revelação (consciente ou não) de informações pessoais, consistentes com a imagem que o usuário deseja passar (KAPLAN; HAENLEIN, 2010). 


\begin{tabular}{|c|c|c|c|c|}
\hline & \multicolumn{3}{|c|}{ Presença social / Riqueza de mídia } \\
\hline & & Baixo & Médio & Alto \\
\hline \multirow{2}{*}{$\begin{array}{c}\text { Auto } \\
\text { Apresentação } \\
/ \\
\text { Auto } \\
\text { divulgação }\end{array}$} & Alto & $\mathrm{B} \log \mathrm{s}$ & $\begin{array}{c}\text { Redes Sociais } \\
\text { (ex: Facebook, Instagram) }\end{array}$ & $\begin{array}{c}\text { Mundos Virtuais } \\
\text { Sociais (ex: Second } \\
\text { Life) }\end{array}$ \\
\hline & Baixo & $\begin{array}{c}\text { Projetos } \\
\text { Colaborativos } \\
\text { (ex: Wikipedia) }\end{array}$ & $\begin{array}{l}\text { Comunidades de } \\
\text { Conteúdo } \\
\text { (ex: Youtube) }\end{array}$ & $\begin{array}{c}\text { Mundos de Jogos } \\
\text { Virtuais } \\
\text { (ex: World of War } \\
\text { Craft) } \\
\end{array}$ \\
\hline
\end{tabular}

Pesquisadores sugerem que os ambientes online e offline diferem um do outro, visto que seus participantes constroem e reconstroem juntos seus próprios ambientes virtuais através da interação social. Retomando Sheth e Solomon (2014) e a aproximação da tecnologia e do corpo, nossos corpos continuam a se misturar e se confundir com nossos ambientes. O ditado que antes definia o indivíduo como "você é o que você veste", agora passa a defini-lo como "você é o que você posta". Segundo Subrahmanyam et at. (2008), mensagens online e redes sociais possibilitam a comunicação instantânea entre indivíduos, o que os mantém interconectados o tempo todo. Porém, isso não significa, necessariamente, que os mundos online e offline dessas pessoas sejam imagens espelhadas um do outro:

\footnotetext{
"Ao se comunicarem online, os jovens podem expressar preocupações offline e interagir com pessoas de suas vidas offline, mas de uma forma adaptada aos reconhecimentos do contexto online, como suas oportunidades (ex: habilidade em criar um perfil público de si mesmo e possuir uma extensa rede de amigos) e limitações (ex: interação aberta e visível e menos "pistas" detalhadas da conversa cara-a-cara) (SUBRAHMANYAM et al., 2008, p.432)."
}

Para os indivíduos que estão passando por um momento de incerteza e estão experimentando um período de exploração e auto reconhecimento, as mídias sociais e as postagens de fotos, comentários e informações são uma forma de testar suas identidades ou, ajudá-los a encontrar suas identidades ideais em uma realidade virtual (MANAGO et al., 2008). Alguns estudos em mídias sociais como Facebook, por exemplo, sugerem que jovens adultos utilizam essas redes como "fóruns", e realizam tarefas e funções que demonstram sua personalidade, a fim de explorar e expressar suas características pessoais, suas identidades reais (BACK et al., 2010; TOSUN, 2012).

Lembrando que, no mundo online não possuímos mais um core self, qualquer pessoa que tenha um perfil no Facebook já teve a ilusão de que esse core self existe 
e está ali, descrito invisivelmente nas entrelinhas das postagens (BELK, 2013). Apesar disso, Sorapure (2003) observa que em uma rede social como essas - quase que um diário online da sua vida - fragmentos de informação sobre o self de cada um são, indiretamente, agrupados de diferentes formas, apresentando então múltiplas e constantes alterações na compreensão deste self. Com estas diferentes representações do self, cada vez mais usuários criam múltiplas identidades virtuais (SCHAU; GILLY, 2003), não se atendo a uma ou duas, mas a várias delas, com estratégia digital de representação de si mesmos.

Porém, Zwier et al. (2011) demonstram em pesquisas que o excesso na demonstração dessa identidade real, ao mesmo tempo que leva a inferências de que o dono do perfil deseja articular suas qualidades, também tem um efeito prejudicial na conclusão de que estas qualidades são reais, afetando, de forma negativa, a conexão social com os demais.

Alguns estudiosos relatam o "efeito Proteus", em que algumas experiências vividas pelas pessoas no mundo online influenciam seus comportamentos $\mathrm{e}$ as características do self quando retornam para o mundo offline (mundo real) (YEE; BAILENSON; DUCHENEAUT, 2009). A tecnologia está em um patamar tão avançado, que nos permite fazer o download e repassar a nossa essência, o nosso self e personalidade para dispositivos digitais. Como se passássemos nosso self de um corpo para outro corpo (GRAFFAM, 2012), assim como sugeriu (BELK, 2013) quando citou, dentre outros progressos, o reembodiment. Neste caso, nossa essência está passando para um arquivo digital, e não uma posse (objeto).

Porém, como exemplo, em relação a jogos online, Belk (2014a) afirma que, mesmo passando muitas horas em jogos virtuais, essas realidades são menos efetivas como demonstrações do nosso self quando comparadas com bens tangíveis, visto que são visíveis apenas para outros participantes que se encontram online e dentro do contexto dos jogos. Já nas mídias sociais, o mesmo não pode ser afirmado. Retomando a construção compartilhada do self (BELK, 2013), a identidade é construída em conjunto especialmente quando fala-se de mídias sociais. Ao postar fotos, vídeos e mandar e-mails e/ou mensagens, pessoas de todas as partes do mundo podem visualizar, comentar, criticar e sugerir modificações (BELK, 2014a). As identidades construídas no mundo online não são, necessariamente, novas, visto 
que podem ser divisões do self encontradas nas interações ao vivo, ou seja, o self online é muitas vezes uma parte de uma identidade maior (BAPTISTA, 2003).

Ainda, outros estudos indicam que jovens adultos navegam nas diferentes mídias digitais com o propósito de repassar aos seus amigos e/ou familiares suas crenças e atitudes em diferentes contextos (COYNE; PADILLA-WALKER; HOWARD, 2013; GREENWOOD; LONG, 2009; HORTON; WOHL, 1956). Neste caso em específico, quando fala-se de criação, formação e exploração de identidade, definitivamente a mídia pode influenciar em diferentes níveis (COYNE; PADILLA-WALKER; HOWARD, 2013). Como bem definido por Horton e Wohl (1956): "Nada poderia ser mais razoável ou natural do que aquelas pessoas que estão isoladas e solitárias, buscarem sociabilidade e amor em qualquer lugar que elas acham que podem encontrar" (p. 223).

Greenwood e Long (2009) sugerem um uso da mídia de forma compensatória, ou seja, indivíduos desenvolvem apego emocional em relação a certos personagens (e suas características), admitindo substitutos sociais que permitem que eles se transportem para as narrativas ilusórias, a fim de lidar com momentos de solidão e perda. Ainda segundo os autores, essa prática pode elevar o autoconhecimento a partir da identificação.

Frente a esse crescimento das mídias sociais, percebe-se uma democratização da comunicação corporativa em que indivíduos e comunidades detém o poder - antes do marketing e de relações públicas - de criar, compartilhar e consumir informações sobre as marcas, com ou sem permissão das mesmas (KIETZMANN et al., 2011).

\subsubsection{1}

\section{A Auto Apresentação e o Compartilhamento de Fotos nas Mídias Sociais}

Com o crescimento e desenvolvimento das mídias digitais, câmeras digitais de alta qualidade e smartphones com aparelhos fotográficos poderosos começaram a surgir. A facilidade no manuseamento das telas destes dispositivos promoveram um aumento considerável na quantidade de imagens capturadas e compartilhadas, não apenas com amigos e familiares íntimos, mas também através de postagens online para o mundo inteiro.

Kindberg et al. (2005) realizaram um estudo com usuários americanos e ingleses para entender as diferentes intenções por trás das imagens capturadas, fossem elas 
compartilhadas ou não, através de duas dimensões: razões afetivas versus funcionais e intenções sociais versus individuais. Resultados indicaram que dois terços das imagens haviam sido capturadas com o propósito final de compartilhamento, por motivos afetivos, sendo este compartilhamento com terceiros realizado ainda na presença dos mesmos. Ainda, Van House (2009) acrescenta que poder ver a imagem na tela do dispositivo imediatamente após ser capturada, foi uma das características mais significativas do avanço tecnológico. O autor também afirma que é comum a prática de mostrar aos colegas essa imagem capturada para que todos possam vê-la e aprová-la (ou não).

A teoria de Goffman (1956) sobre a auto apresentação afirma que, na sociedade, indivíduos adotam diferentes identidades, de acordo com fatores como o público e situações. Indivíduos têm a capacidade de interpretar diferentes papeis, o que faz com que eles se preocupem em manter a impressão de que vivem de acordo com todos os padrões pelos quais eles e todos os produtos são julgados (GOFFMAN, 1956).

Inseridas neste conceito de auto apresentação e interação social, as mídias sociais são plataformas dentro das quais estes mesmos indivíduos podem construir diferentes apresentações públicas de si mesmos (MARSHALL, 2010) e, portanto, diferentes identidades (BULLINGHAM; VASCONCELOS, 2013), através da edição e compartilhamento de fotos - principalmente, da aparência física - para uma audiência imaginária (FOX; VENDEMIA, 2016).

A Teoria da Objetificação (FREDRICKSON; ROBERTS, 1997) e a Teoria da Comparação Social (FESTINGER, 1954) servem de base para explorar a auto apresentação e a comparação social através de fotografias compartilhadas nas mídias sociais. Ferramentas de compartilhamento de fotos promovem a objetificação do self (FREDRICKSON; ROBERTS, 1997), enquanto a visibilidade destas fotos e o feedback (comentários e curtidas) encorajam a comparação social (FESTINGER, 1954). Ainda, de acordo com a Teoria da Objetificação, essa experiência de compartilhar fotos e se sentir "monitorado" o tempo todo por terceiros, chamada de autoconsciência objetiva, traz implicações para a autoimagem do indivíduo, especialmente mulheres (FREDRICKSON; ROBERTS, 1997). 


\subsubsection{1 \\ O Compartilhamento de Fotos no Instagram}

O Instagram (Figura 1, (a)) é um serviço para celulares que visa a captura e compartilhamento de fotos e vídeos, que proporciona aos usuários a possibilidade de fotografar, editar suas fotos (Figura 1, (b, c)) e compartilhar momentos de vida com seus amigos, através de uma série de imagens (HU; MANIKONDA; KAMBHAMPATI, 2014).

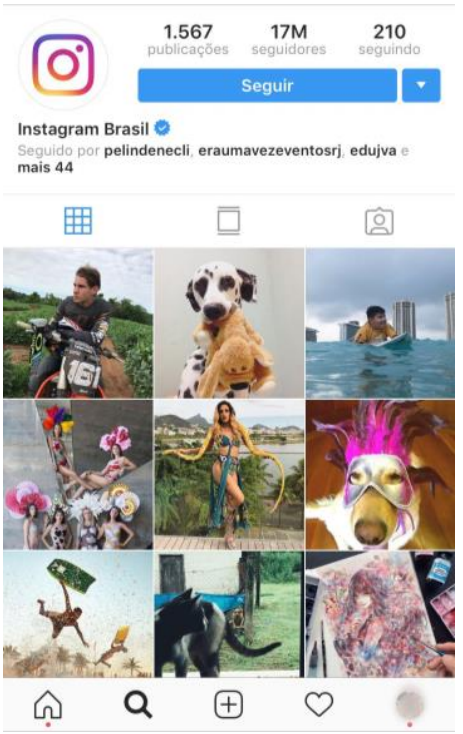

(a)

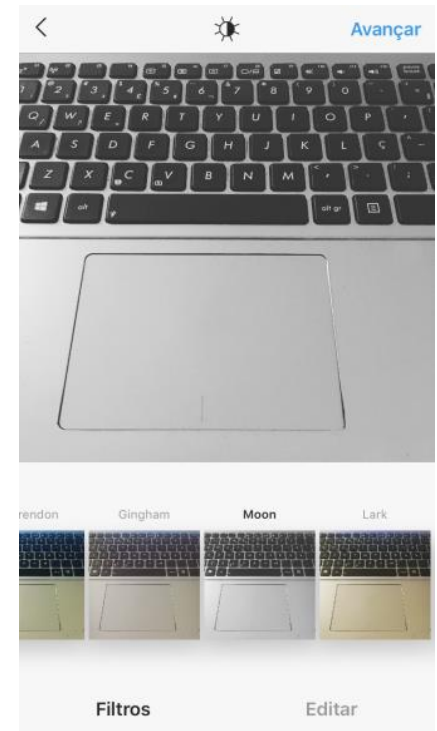

(b)

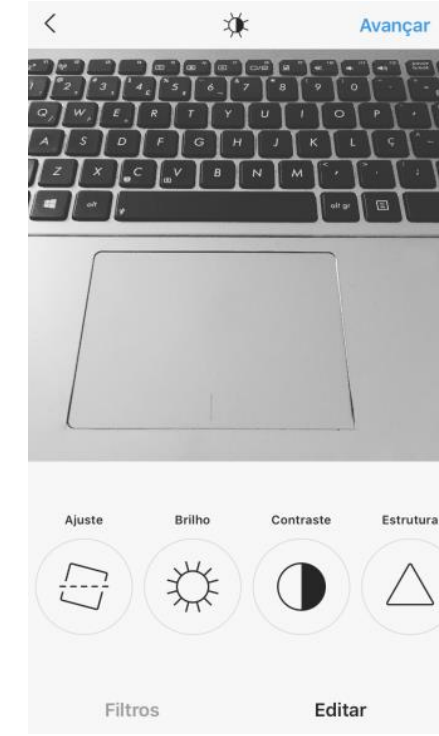

(c)

Figura 1: Interfaces do Instagram. (a) Página Principal, (b) Utilização de Filtros 1, (c) Utilização de Filtros 2.

A rede permite a inclusão de legendas, hashtags (\#), e possibilita a marcação de pessoas através do símbolo @, que cria um link entre a foto do usuário e o amigo marcado na foto (HU; MANIKONDA; KAMBHAMPATI, 2014). Através da rede social, usuários podem seguir "amigos" e podem ser seguidos pelos "seguidores" ambos os nomes dados pelo próprio programa -, porém não havendo necessidade de se seguirem mutuamente, sendo o Instagram uma rede assimétrica. Como configuração padrão, as imagens e vídeos são públicos, ou seja, visíveis para todos que utilizam o aplicativo, porém o usuário pode trocar a privacidade para "privado", o que obriga o seguidor a solicitar permissão para ver as postagens (HU; MANIKONDA; KAMBHAMPATI, 2014). Dado isto, o Instagram é uma forma de corrente de consciência social (Social Awareness Stream), assim como outras plataformas, dentre elas Facebook e Twitter (NAAMAN; BOASE; LAI, 2010). 
Atualmente, usuários utilizam a rede como primeiro mecanismo de compartilhamento de fotos, repassando para as outras redes sociais após postagem (HU; MANIKONDA; KAMBHAMPATI, 2014).

O Instagram proporciona três vantagens, quando comparado às outras mídias sociais: é a única rede social que foi lançada diretamente para celulares, ao invés da internet, não é uma rede voltada para conversação como o Facebook e o Twitter, e o conteúdo das postagens tem maior durabilidade do que em outras redes (MILES, 2014).

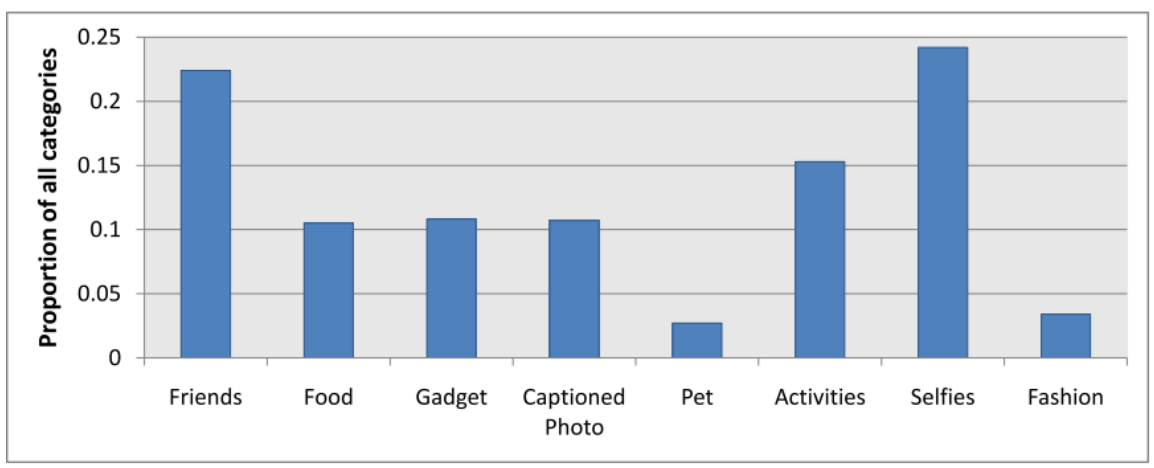

Figura 2: Proporção de Categorias (HU; MANIKONDA; KAMBHAMPATI, 2014).

As fotos do Instagram podem ser categorizadas em oito tipos, sendo eles divididos em autorretratos, amigos, atividades, fotos com textos, comidas, instrumentos, moda e pets, assim como há cinco diferentes tipos de usuários (HU; MANIKONDA; KAMBHAMPATI, 2014).

\section{4}

\section{A Imagem do Corpo nas Mídias Sociais}

\subsection{1}

\section{O Modismo como Influência}

Há inúmeras situações sociais em que somos direta ou indiretamente influenciados na tomada de decisões, a partir do que outras pessoas estão fazendo. No dia-a-dia, em exemplos simples, decidimos a qual restaurante ir ou qual escola estudar com base na popularidade dos mesmos.

\footnotetext{
"Sempre que imitamos, transferimos para outra pessoa não só a demanda por uma atividade criativa, como também a responsabilidade pela a ação. Assim, o indivíduo está livre da preocupação de escolher e aparece, simplesmente, como uma pessoa a mais dentro de um grupo, como um recipiente dos conteúdos sociais" (SIMMEL, 1957, p. 542$543)$.
} 
O modismo é caracterizado por uma preocupação não tradicional por coletividades difusas em relação a um objeto e/ou processo circunscritos (SIMMEL, 1957). Considerado uma forma de comportamento coletivo, dentre suas características estão a homogeneidade - característica encontrada em diferentes momentos e lugares -, a novidade - novos comportamentos - e estranheza - evocam desaprovação por àqueles que não aderem à moda (AGUIRRE; QUARANTELLI; MENDOZA, 1988). Ainda, o modismo é inesperado (BLUMER, 1964), de rápida disseminação (LANG; LANG, 1961), de rápida aceitação (BLUMER, 1968).

A influência social é uma área estratégica para a pesquisa de redes sociais, pois liga a estrutura das relações sociais com atitudes e comportamentos dos usuários das redes (MARSDEN; FRIEDKIN, 1993). Segundo Burt (1987), a base estrutural desta influência está no fato de que algo relacionado às circunstâncias da estrutura social do ego e do alter ego faz com que se aproximem, de forma que o ego avalie, sensivelmente, a inovação, até que o alter ego a adote. Já Cartwright, (1965) afirma que esta influência é "simplesmente uma instância especial de casualidade, ou seja, a modificação das respostas de uma pessoa pelas ações de outra” (p.3).

A única condição necessária para que uma influência ocorra é a informação difundida sobre atitudes e comportamentos de terceiros, o que permite a comparação social (MARSDEN; FRIEDKIN, 1993). A externalidade do consumo se dá através da utilidade que um usuário atribui a um bem de consumo que, por sua vez, depende do número de outros usuários que estão em sua rede e que também usam aquele bem (KATZ; SHARPIRO, 1985).

Outra explicação para o comportamento coletivo é a Cascata de Informações indivíduos recebem informação a respeito do valor real/abstrato do item ou serviço e, apesar desta informação estar, muitas vezes, incompleta, determinam o valor esperado com base nas decisões de indivíduos anteriores. Se este valor for maior do que o custo de adoção, eles aderem à moda (BANERJEE, 2010).

Isto pode acarretar no contágio comportamental - caracterizado pela imitação ou aquisição espontânea de um comportamento iniciado por um indivíduo que, por sua vez, não tinha intenção de "contagiar" ninguém - ou na influência direta - em que o indivíduo tem a intenção de disseminar um comportamento, causando a imitação por terceiros (LIPPITT; POLANSKY; ROSEN, 1952). O impacto social se dá através de qualquer influência sobre os sentimentos, pensamentos ou 
comportamentos de um indivíduo, exercida pela presença ou ações reais, implícitas ou imaginárias de outros (LATANE, 1981).

Alguns indivíduos buscam orientações normativas quando estão incertos de suas escolhas, e se envolvem no processo de imitação - tomada de papeis - enquanto procuram alguns modelos comportamentais que se adequem ao grupo social ao qual pertencem (BURT, 1987), o que se assemelha ao isomorfismo mimético de DiMaggio e Powell (1983). Estas pessoas são, simultaneamente, amigas e competidoras, e cada uma delas contribui para a capacidade de resposta de uma para a outra (MARSDEN; FRIEDKIN, 1993).

Quando o envolvimento pessoal de um indivíduo a determinando assunto é baixo, pouca atenção é dada às mensagens e, neste caso, a persuasão ocorre através de "pistas periféricas" (HASS, 1981), confiabilidade (EAGLY; WOOD; CHAIKEN, 1978), atratividade (CHAIKEN, 1979) e similaridade com o self (GOETHALS; NELSON, 1973). As "pistas periféricas" vêm através da força - representada através da credibilidade e atratividade das fontes -, imediatismo - através da proximidade física -, e o número de pessoas que defendem o contrário (NOWAK; SZAMREJ; LATANÉ, 1990).

\subsubsection{1}

Tribos

Com o advento das mídias digitais, mídias sociais e a facilidade em realizar tarefas como a busca por informações e aquisição de produtos através da internet, os consumidores foram se tornando cada vez mais individualistas (COVA; COVA, 2002). Sair de casa e ter uma vida social passou a ser algo incomum na sociedade atual (COVA, COVA, 2002).

Porém, algumas tentativas de recomposição social têm sido visíveis na sociedade, como o surgimento de novas comunidades e arranjos sociais alternativos (GOULDING; SHANKAR; ELLIOT, 2001). Cada vez mais indivíduos estão se juntando e participando de diferentes grupos que possuem maior influência sobre seus comportamentos (COVA, COVA, 2002). O triunfo do individualismo deu lugar ao início de uma busca pela preservação, ou até mesmo a (re)criação, de um link social (MAFFESOLI, 1996), observando-se, assim, o surgimento do “tribalismo" (BAUMAN, 1990; MAFFESOLI, 1996). 
A palavra "tribo" se refere à emergência de valores até então considerados arcaicos: um senso de identificação, religiosidade e sincretismo (COVA, COVA, 2002). Segundo Cova e Cova (2002), "Tribo" traz as mesmas noções de "grupo étnico", porém em uma escala menor, através de uma homogeneidade local, linguística e cultural; ainda, engloba características de “clã", mas em uma escala maior de parentesco, linhagem e atributos relacionados. Vale ressaltar que as tribos pósmodernas são instáveis, de pequenas escalas, afetivas (MAFFESOLI, 1996) e livres de qualquer parâmetro estabelecido pela sociedade atual (COVA, COVA, 2002). Elas são temporárias, se mantém através de emoções e paixões compartilhadas e exibem laços muito fortes principalmente devido essa temporalidade (KOZINETS, 1999). As tribos existem devido o compromisso simbólico e ritualístico manifestado pelos seus membros, e a construção e posse cíclicas de significados através das experiências compartilhadas de seus membros são a forma mais potente de manter a identidade da mesma (COVA, COVA, 2002).

Os autores Cova e Cova (2002) ainda afirmam que cada indivíduo pode pertencer a múltiplas tribos com diferentes características e, em cada uma delas, possuir um papel específico com personalidades diversas. A interação social da tribo ocorre através dos valores em comum associados a bens e serviços apreciados pelos consumidores pertencentes a essa tribo (COVA; COVA, 2022). Devido a efemeridade das tribos, elas necessitam consolidar e afirmar sua união através de quaisquer atributos que facilitem e deem suporte a essa união, seja um lugar, um emblema, uma marca, ou a ajuda de um ritual de integração ou reconhecimento (THOMPSON; HOLT, 1996).

\subsection{2}

\section{A Aparência Física que Constrói a Identidade}

$\mathrm{Na}$ atual modernidade, a busca pela identidade pessoal se torna cada vez mais forte. Indagações como "o que fazer", "como agir" e "quem ser" são comuns para todos os que vivem nas atuais circunstâncias tecnológicas, e a reflexividade do self, citada por Giddens (1991), se estende para a imagem corporal e visível: “o corpo é parte de um sistema de ação, e não apenas um objeto passivo" (p.77).

Retomando a Teoria da Objetificação, mulheres assumem uma perspectiva de fora de si mesmas e avaliam, criticamente, seus valores e imagem com base nos padrões sociais, por exemplo, priorizando a aparência, e começam a se auto objetificar, 
aprendendo a se valorizar de acordo com a aparência física (FREDRICKSON; ROBERTS, 1997). Ou seja, estrutura-se a imagem de corpo dotada de materialidades como forma de construção da identidade. Ainda, conforme (ROOK, 1985) cita, as mulheres colocam mais o emocional em seus próprios corpos, acabando por utilizar mas produtos para cuidar destes, objetificando ainda mais suas próprias imagens.

Ainda, a Teoria da Comparação Social sugere que indivíduos se auto avaliam ao julgar outros indivíduos, por exemplo de mesma idade e sexo, identificando diferenças favoráveis e não favoráveis, partindo, principalmente, para comparações de aparência física (FESTINGER, 1954). Na mídia, imagens de aparências e modelos perfeitos são apresentadas como sendo reais, das quais se retiram marcas de degradação, secreções, brilhos de pele, fluidos, entre outros, fazendo com que as pessoas se comparem e acabem por buscar, cada vez mais, a perfeição (CORDEIRO, 2011).

Retomando Goffman (1956), a auto apresentação é um processo complexo de negociação entre o que realmente somos e o que queremos apresentar aos outros, o que faz com que as pessoas troquem, constantemente, de estratégia de apresentação, de acordo com os objetivos, contextos e audiências interpretados.

\subsubsection{1 \\ A Prática de Esporte, o Branded Fitness no Crossfit e a Busca pelo Aprimoramento do Self}

Realizar exercícios é uma realidade diária na vida de milhões de consumidores, seja de manhã, antes de sair para trabalhar, ou à noite, após as obrigatoriedades do dia (POWERS; GREENWELL, 2016). Exercícios aumentam a qualidade de vida, estão diretamente relacionados com a autoestima (MCAULEY; RUDOLPH, 1995), além de estarem associados com o bem-estar psicológico através da sensação de realização e dever cumprido, aprimoramento da imagem do corpo e redução de estresse (KLEIN et al., 1985).

Desde os anos 70, com o boom do movimento moderno fitness Americano, numerosos modismos, movimentos e atividades surgiram e desapareceram, e consumidores têm sido encorajados a manter atividades físicas diárias em troca de um corpo magro, saudável e sempre jovem (POWERS; GREENWELL, 2016). Durante os anos 80, as academias se tornaram locais significativos para a troca 
social, oferecendo um local, além do lar e do trabalho, em que as pessoas podiam interagir com outras que compartilhassem dos mesmos interesses, aumentando o senso de pertencimento (MCKENZIE, 2013). Dentre estas motivações pessoais para a prática do esporte, entre os jovens notam-se a busca pela diversão, desafios, desenvolvimento de habilidades e boa forma física (MCGUIRE; COOK, 1983; ROBINSON; CARRON, 1982), enquanto entre os adultos encontram-se motivos como liberação de tensão, fatores sociais, saúde e fitness (BIDDLE; BAILEY, 1985). O suporte e incentivo de amigos também são marcadores importantes para a motivação na hora de praticar exercícios (COURNEYA et al., 2000). Esta influência pode ocorrer caso o(a) amigo(a) pratique exercícios regularmente, ou até mesmo através de feedbacks positivos da atividade (BOOTH et al., 2000). Ainda, segundo Darlow e Xu (2011), as pessoas costumam realizar exercícios baseados naqueles que as pessoas mais próximas estão executando, além de buscarem aproximação com aqueles que seguem comportamentos de saúde similares como tipo de alimentação e hábitos de atividades físicas (BAHR et al., 2009). Dishman, Sallis e Orenstein (1985) afirmam que fortes motivos para os indivíduos permanecerem em um determinado esporte estão na automotivação, novas habilidades comportamentais, tempo livre e a percepção de boa saúde.

Segundo Powers e Greenwell (2016), o avanço mais importante e significativo durante os anos foi a transformação permanente e desmedida que afetou não apenas como as pessoas se exercitam, mas também que papel o exercício desempenha em suas vidas, incluindo o crescimento desenfreado de realização de atividades do branded fitness (atividades conhecidas e renomadas para manter a boa forma branded - que dominaram a segunda metade do século XX). Estas novas formas de exercício envolvem instrutores ou técnicos que guiam grupos de participantes através de um grande conjunto de atividades, e ocorrem em espaços fechados e dedicados (muitas vezes com altas taxas de filiação) que incluem alimentos, equipamentos, adereços, serviços e mídias sociais (POWERS; GREENWELL, 2016). Quem adota estas atividades, transcende ao exercício de academia comum, passando a se engajar em um "modo de vida" que demanda um tempo substancial e social, além de investimento financeiro (POWERS; GREENWELL, 2016). Muitos autores argumentam que as atividades fitness se tornaram comodificadas (MAGUIRE, 2007; MILLINGTON, 2014; SCOTT, 2011). Primeiro, nações que 
antes impulsionavam o modo de vida fitness como forma de preparar os cidadãos para o serviço militar, agora enfatizam a gestão da saúde para a prevenção de doenças, busca mais individualizada que se adapta melhor à marketização (MAGUIRE, 2007; SHILLING, 2012). Segundo, com a atual cultura da aparência, ser fitness tem se tornado, cada vez mais, sinônimo de beleza do que atingir metas para uma saúde saudável (BOLIN; GRANSKOG, 2003; DWORKIN; WACHS, 2009). Assim, a preocupação com aparência e desejo que antes eram disseminadas em outras áreas do mercado, agora foram estendidas ao próprio corpo. Como Shilling, (2012) afirma, atualmente entendemos nossos corpos não apenas como algo natural, mas como fenômenos com diversas opções, escolhas e entidades em processo de eterno desenvolvimento. Para atingir a forma física desejada, é preciso se esforçar e, continuamente, comprar acesso, bens e produtos para ajudar neste esforço (POWERS; GREENWELL, 2016). Estes aparatos fitness marcam, portanto, grande mudança em como consomem-se os exercícios e imaginam-se seus benefícios, tornando-os elemento de marca pessoal do consumidor, assim como uma marca em si (POWERS; GREENWELL, 2016).

O conceito de Scott (2010) sobre Instituições Reinventivas oferece conhecimentos valiosos sobre a transformação pessoal voluntária e a reconstrução da identidade, fornecendo ferramentas analíticas multidimensionais e úteis para entender o esporte e, no caso desta dissertação, o crossfit, a partir de uma perspectiva.

Em busca de uma adaptação de Goffman (1961) acerca da conceptualização do asilo como uma Instituição Total (TI - Total Institution), Scott (2010) apresenta a ideia de uma Instituição Reinventiva (RI - Reinventive Institution):

\footnotetext{
"Estrutura material, discursiva ou simbólica, através da qual membros voluntários buscam, ativamente, cultivar uma nova identidade social, papel ou status. Isto é interpretado positivamente como um processo de reinvenção, aprimoramento pessoal ou transformação. É atingido não apenas através de instruções formais em uma retórica institucional, mas também através dos mecanismos de regulação performativa no contexto de interação de uma cultura interna" (SCOTT, 2010, p.226).
}

O conceito de Scott (2010) elucida o processo de "aprimoramento pessoal voluntário", que acompanhou as tardias modificações modernas saindo de institucionalização coercitiva - em que as pessoas se internavam em instalações para se submeterem a uma transformação de identidade - para a autoajuda e introspecção como meio de reabilitação - em que indivíduos buscam, 
autonomamente, adesão a instituições (esportivas) como veículos para mudanças de identidade (SCOTT, 2011). Ao contrário das bases da Instituição Total, que busca eliminar partes indesejadas do self (GOFFMAN, 1961), a Instituição Reinventiva busca cultivar um self totalmente novo, positivamente construído como uma mudança no estilo de vida (SCOTT, 2011). Esta ideia de voluntarismo que domina a Instituição Reinventiva transmite a impressão de que a escolha de identidades é ilimitada e que as pessoas que a seguem podem selecionar e construir quaisquer identidades ideais que queiram. Porém, através de diversos exemplos de IRs, Scott (2011) refuta correntes subsequentes e sugere que ao invés de embarcar em uma jornada individualista de descobrimento pessoal, as pessoas acabam por conseguir apenas "McSelves" (p. 39), ou seja, identidades genéricas, não muito diferentes das questões hospitalares padrões dos asilos de Goffman (1961). Scott (2011) menciona, portanto, a "regulação performativa", referência direta ao tipo de poder que opera as IRs, experimentado como benigno, capacitador e benéfico para o objetivo de auto aperfeiçoamento. Para explicar por que as pessoas buscam voluntariamente esse tipo de arranjos institucionais e os percebem como benéficos, Scott (2011) cita a ordem de interação de Goffman (1983), que sugere que atores sociais trabalham de forma colaborativa a fim de criar e manter uma 'definição de situação' (GOFFMAN, 1983). Este contexto de interação é particularmente importante no Crossfit, como será discutido mais à frente.

\subsubsection{2}

\section{A Aparência Física Através do Esporte}

O corpo se tornou objeto fundamental de consumo. As atividades esportivas se tornaram uma forma de consumo e por meio desse consumo, o indivíduo constrói sua identidade (BELK, 1988; CORDEIRO, 2011) e participa de grupos que lhe tragam a sensação de pertencimento, essenciais ao sentido de identidade (CORDEIRO, 2011).

O esporte transforma o corpo e o altera fisicamente, o que faz com que os indivíduos tenham maior confiança em si mesmos e sejam aceitos em suas comunidades de interesse (CORDEIRO, 2011).

Essas modificações do corpo possibilitam alterações das narrativas de auto identidade e são decisivas na construção da mesma, visto que a exposição do corpo passou a ter um valor altíssimo na sociedade atual (CORDEIRO, 2011). O corpo 
responde a uma construção identitária, sendo modelado a partir dos padrões difundidos pela mídia, e é por meio da aparência que o indivíduo torna visível sua identidade (CORDEIRO, 2011). Estas alterações aumentam, significativamente, a confiança dos jovens em si mesmos (CORDEIRO, 2011).

\subsubsection{1}

\section{A Importância do Corpo e das Selfies nas Mídias Sociais}

O compartilhamento de fotos online tem se mostrado fortemente relacionado a autovalorização (STEFANONE; LACKAFF; ROSEN, 2011).

Com as diferentes configurações oferecidas pelas mídias online, os indivíduos conseguem customizar cada vez mais suas identidades e apresentações (SMITH; SANDERSON, 2015), e todas as situações se transformam em meras representações da realidade, em que as pessoas aspiram ser apenas imagens de si mesmas, ou seja, celebridades (SONTAG, 2015). Ainda, plataformas online permitem a exposição de identidades que, muitas vezes, não são apropriadas ou desejáveis em um encontro face-a-face (KIM; PAPACHARISSI, 2003).

Com essa difusão na mídia, a preservação da saúde e uma aparência melhor passaram a ser primordiais. A consciência do corpo e imagem faz com que a mente dos indivíduos observe este corpo como algo a ser complementado e construído, criticando sua aparência e forma, o que acaba por induzi-las a realizar diferentes atividades como exercícios físicos, cirurgias, dietas, a fim de transformar este corpo em uma forma mais desejada (THOMPSON; HIRSCHMAN, 1995). Usar o corpo como um elemento a ser modificado, é uma forma de unir o self a este corpo, de forma a harmonizar e integrar o todo (GIDDENS, 1991), e fazer com que a exposição dele assegure não só a difusão, mas a própria construção da identidade (CORDEIRO, 2011).

O aumento no nível de narcisismo entre os millenials (TWENGE et al., 2008) em conjunto com o desenvolvimento das redes sociais fizeram com que os indivíduos com alto grau de narcisismo se tornassem muito ativos nestas redes (ONG et al., 2011), aproveitando para publicar conteúdos voltados para a promoção se si mesmos, de seus corpos e beleza (MEHDIZADEH, 2010). Tirar e compartilhar selfies (neologismo utilizado para descrever o ato de tirar um autorretrato e compartilhar nas mídias (SHIN et al., 2017)) se tornou algo muito comum com o advento dos smartphones e mídias sociais (SUNG et al., 2016). No Instagram, por 
exemplo, indivíduos mais narcisistas tendem a publicar mais selfies e atualizar suas fotos de perfis mais vezes se comparados a indivíduos menos narcisistas (FOX; ROONEY, 2015).

As selfies refletem as personalidades dos indivíduos e ajudam a transmitir seu autoconceito ideal, fazendo com que busquem afirmação de terceiros para reforçar este último (SHIN et al., 2017).

Comparadas aos homens, mulheres demonstram maior foco na aparência em seus perfis de redes sociais (HAFERKAMP et al., 2012), visto que se sentem mais pressionadas a se adequarem às normas de gênero e beleza, e postar fotos mais atraentes (CHUA; CHANG, 2016). Estudos feitos no Facebook demonstram que, mulheres com maiores tendências à comparação social têm maior probabilidade de desenvolver mau humor e insatisfação corporal quando navegam na rede, em comparação com a visualização de um website mais controlado (FARDOULY et al., 2015). Nas mídias sociais, as pessoas tendem a apresentar e interpretar as informações, comentários, feedback de fotos, de acordo com seus próprios sentimentos, estado mental e pontos de vista, a fim de aumentar sua autoestima (BAREKET-BOJMEL; MORAN; SHAHAR, 2016). Indivíduos que compartilham suas selfies nas redes sociais demonstram um aumento de autoestima (GONZALES; HANCOCK, 2011; SHIN et al., 2017).

\section{5 \\ O Crossfit no Mundo}

Conhecido como o "esporte da boa forma" (the sport of fitness), o crossfit é uma nova e crescente modalidade de exercício que, além de superar o crescimento de outras franquias de fitness mais conhecidas, se transformou em uma das maiores tendências do século XXI (DAWSON, 2017). Em junho de 2014, o crossfit atingiu 10 mil afiliados em todo o mundo (BEERS, 2014).

Como uma entidade corporativa, o crossfit surgiu em meados de 2000, com o ginasta Greg Glassman, que acreditava que cronogramas regulares de treinos não eram desafiadores o suficiente, e em busca de uma rotina que melhorasse sua performance, o ginasta começou a experimentar novas formas de levar seu corpo ao limite (HERZ, 2014). Assim, Glassman desenvolveu, não apenas uma série de exercícios, mas diversas rotinas de séries que implicavam em movimentos funcionais constantes, executados em alta intensidade (HERZ, 2014). 
Os praticantes de crossfit são atraídos, principalmente, pela rotina de treino dinâmica do esporte, visto que acham monótonos métodos de treinos convencionais, como levantamento de peso e atividades gerais de academias (HERZ, 2014; SPREY et al., 2016).

O Crossfit busca produzir e aprimorar o poder humano e sua forma física através do domínio de 10 habilidades: resistência cardiovascular e respiratória, estamina, força, flexibilidade, poder, velocidade, coordenação, agilidade, equilíbrio e precisão (GLASSMAN, 2002).

Ainda, o esporte se auto descreve como uma comunidade que surge de forma espontânea quando indivíduos se juntam para realizar os exercícios (GLASSMAN, 2004). O local de prática do crossfit é normalmente pequeno, uma sala denominada "box", com equipamentos minimalistas, oferecendo aos participantes pouca ou nenhuma oportunidade para serem autônomos ou anônimos (GLASSMAN, 2004), em contraste com tradicionais ambientes de ginástica, em que os clientes podem criar barreiras virtuais entre eles e terceiros, enquanto ouvem músicas, leem ou assistem televisão durante a prática de suas séries (DAWSON, 2017). Para os crossfitters, treinos em grupo requerem participação e interação de todos, o que explica a criação de uma comunidade de Crossfit (GLASSMAN, 2011). Segundo o praticante de crossfit Allison Belger (2012), a conexão social e o senso de comunidade são tão essenciais para a eficácia e popularidade do crossfit quanto seus princípios e metodologias.

O crossfit se encaixa diretamente no branded fitness, que prova que, diferente das dietas, em que a incorporação da marca acontece, principalmente, através da exibição do próprio corpo, ele está ligado diretamente ao que o corpo é capaz de fazer (POWERS; GREENWELL, 2016). O branded fitness - neste caso, o crossfit - é intrinsicamente fenomenológico, se manifesta e é realizado através dos movimentos corporais, que provam que séries, movimentos e filosofias podem sim pertencer a quem os realiza. Esta relação de posse com certos exercícios e formas que estes são aplicados prova que consumidores que realizam esportes conhecidos (branded fitness - crossfit) podem fazer movimentos e atividades que outros não podem (POWERS; GREENWELL, 2016). Nossos corpos, que antes eram considerados manifestações físicas de nossos valores morais e arbítrios 
(GOLDSTEIN, 1992), agora são potenciais avatares de valor de marca (POWERS; GREENWELL, 2016).

\subsection{1 \\ O Crossfit no Brasil}

No brasil há, aproximadamente, 440 centros de crossfit registrados e certificados, que agrupam em torno de 40 mil atletas no total (SPREY et al., 2016). Em uma avaliação do perfil de praticantes de crossfit no Brasil, Sprey et al. (2016) afirma que grande parte dos atletas são jovens, com idade entre 18 e 39 anos, e média de 31 anos.

As características dos praticantes se assemelham muito àquelas dos americanos citadas no item 2.5 O Crossfit. Os praticantes de crossfit no Brasil já possuíam experiência anterior com algum esporte, e a maioria é fisicamente ativa. Eles se encantam pelo esporte devido a dinamicidade na rotina dos treinos, visto que acham academias ambientes monótonos, e buscam o aprimoramento do condicionamento físico (SPREY et al., 2016).

\section{5 .2}

\section{O Crossfit e a Imagem do Corpo}

O crossfit é um esporte que busca oferecer treinos funcionais para atividades diárias e diversos autores têm explorado a ideia de um fitness funcional e a relação deste com a idealização do corpo feminino. Um estudo de Markula (1995) feito com mulheres evidencia a prática do esporte não apenas como objetivo de alcançar um ideal socialmente construído de corpos elegantes e tonificados, mas também para aumentar a força física para que não haja necessidade de solicitar ajuda em atividades diárias funcionais que exigem força.

O crossfit é considerado o esporte do fitness em que o alcance final da atividade vai muito além da realização do exercício para 'performance atlética', coincidindo mais com uma 'performance corporificada' através da transformação e aprimoramento do corpo (SASSATELLI, 2010).

A promessa de um aprimoramento pessoal e perfeição que permeiam as Instituições Reinventivas (SCOTT, 2011) são claramente evidentes no Crossfit, visto que a ideia principal do esporte é produzir seres humanos superlativos (DAWSON, 2017). Apesar do crossfit ser visto através do aprimoramento físico corporal e do desejo 
de melhorar a si mesmo tornando-se sua melhor versão - não apenas dentro da 'box, mas também além das salas de treino - (BELGER, 2012), sua natureza competitiva aumenta a idealização de que a prática do esporte transforma o atleta amador na pessoa mais fit do mundo (DAWSON, 2017).

\subsubsection{1 \\ O Crossfit e a Construção de Identidade}

Muitos praticantes de exercícios aeróbicos deste modelo fitness adquirem uma identidade particular capaz de capturar a essência do esporte escolhido (MARKULA, 1995). A maioria dos praticantes de crossfit leva em consideração não apenas o que eles fazem durante os treinos, mas também quem eles se tornam com a realização da atividade física (MARKULA, 1995). Os estudos de Belger (2012), Murphy (2012) e Herz (2014) sugerem significativas mudanças de vida e alterações de perspectivas no mundo pessoal do praticante de crossfit desde o início da atividade, deixando clara a incorporação do crossfit como identidade.

Um aspecto interessante de construção de identidade no crossfit está na linguagem própria adquirida. Belger (2012) concluiu uma pesquisa em que os respondentes afirmam possuir uma linguagem compartilhada, em comum com outros praticantes do esporte, que só eles entendem. As conexões mútuas e identificação derivadas de experiências compartilhadas, assim como ser motivado pela culpa e pena, são temas recorrentes no crossfit e na religião (BELGER, 2012). Muitos atributos do crossfit permeiam histórias repletas de características relacionadas ao culto, como devoção ao líder (treinador), suposição de um status elevado, censura de dissidência, inabilidade gradual de se relacionar com pessoas de fora (do grupo), vontade de fazer o que for preciso para atingir objetivos (mesmo que isso inclua vômitos, sangramentos e urinar em público), e o desejo de recrutar novos membros (LALICH; LANGONE, 2006).

Ainda referente à construção de identidade e ao culto, Herz (2014) concorda, baseando-se na reunião frequente de pessoas em um único espaço chamado "box", na promoção de uma dieta especial, na tendência dos devotos de vestirem roupas similares, e no desenvolvimento de uma linguagem específica de WODs, reconhecida apenas pelos próprios praticantes do esporte.

Ao contrário das bases da Instituição Inventiva estudada por Goffman (1961) - em que os indivíduos têm suas identidades pessoais arrancadas através de um processo 
de mortificação, sendo coagidos a construir uma identidade institucionalizada diferenciada e socialmente aceitável -, os indivíduos que iniciam o crossfit constroem ativamente e conscientemente suas próprias identidades e, portanto, reconhecem que estas últimas são melhores versões de si mesmos (SCOTT, 2011). Neste processo de transformação, praticantes de Instituições Reinventivas são audiências de suas próprias performances e performances de terceiros e, ao invés de terem suas identidades desvendadas por uma fonte externa, por vontade própria descartam seus selves (self no plural) antigos na esperança de encontrar algo melhor (SCOTT, 2010).

A mudança de identidade se reflete, também, na transformação física dos crossfitters, como resultado de alterações em suas dietas e exercícios. No caso das mulheres, em particular, o esporte representa uma forma de alcançar o corpo ideal cultivado pelas mídias, no qual ser forte é sinônimo de ser sexy e (COHEN; COLIN, 2014; MARKULA, 1995; WASHINGTON; ECONOMIDES, 2016).

A afirmação de Scott (2011) de que as Instituições Reinventivas produzem McSelves genéricos tem sentido dentro do mundo do crossfit, visto que além de realizarem exercícios e dietas similares, muitas mulheres também se identificam através de roupas similares ("uniformes") como shorts e calças apertadas, meias de cano longo para proteger de arranhões e hematomas, e tênis próprio para crossfit da linha Nano da Reebok, além de uma bandana na cabeça (HERZ, 2014).

\subsubsection{2}

\section{O Crossfit e o Compartilhamento de Fotos}

Além de adquirirem uma identidade em comum, os praticantes de crossfit são constantemente encorajados a divulgar suas séries de exercícios, biografias e fotos em suas redes sociais a fim de motivar terceiros (DAWSON, 2017), o que ilustra perfeitamente a dimensão horizontal do poder que ocorre em Instituições Reinventivas (SCOTT, 2011). Este material virtual tem um papel crítico na performance destes atletas amadores, em que o acesso online livre aos exercícios e a quase todo o material relativo ao Crossfit oferece todo um contexto de interação virtual além da "box" (DAWSON, 2017). Portanto, o crossfit opera de forma física e virtual, em que Scott (2011) define como uma comunidade online, na qual seus membros se encontram e trocam ideias reconstruindo suas identidades constantemente. 


\section{3 \\ Método}

As pesquisas relacionadas ao esporte e às mídias sociais são, em sua maioria, realizadas através de análise de conteúdo e questionários para coleta de dados e, portanto, há ainda oportunidade para expansão de novos métodos durante a evolução estratégica e operacional destas redes (FILO; LOCK; KARG, 2015).

A fim de compreender o modismo esportivo como característica incorporada à identidade a partir da exposição às fotos relacionadas ao esporte publicadas no Instagram, propõe-se aqui o procedimento metodológico de abordagem interpretativa, qualitativa e de caráter exploratório. Pesquisas qualitativas são benéficas para explicar fenômenos e interpretar seus significados através de diferentes técnicas (MINAYO, 1993; PETRESCU; LAUER, 2017), visto que elas enfatizam a reflexão acerca das percepções (COLLINS; HUSSEY, 2005). Ainda, ajudam a descobrir novas variáveis e relações, e a extrair melhor a influência do contexto social e do comportamento humano (ANDRIOPOULOS; SLATER, 2013; COHEN, 1999; COOPER, 2008). Os métodos qualitativos se tornaram ainda mais importantes com o advento das comunicações de consumo online, desde blogs até postagens de mídias sociais e reviews de produtos, em que essas ferramentas qualitativas de análise podem ser utilizadas para pesquisas mais detalhadas e interpretativas (PETRESCU; LAUER, 2017).

As principais características do estudo exploratório são a informalidade e a flexibilidade, realizado a partir de dados secundários, conversas informais, ou estudos de casos selecionados, nos quais procuram-se obter o primeiro contato com a situação pesquisada ou melhor conhecimento sobre o objeto de estudo (SAMARA; BARROS, 2006). A pesquisa foi feita através de entrevistas presenciais, informais e flexíveis, com o objetivo de haver um primeiro contato com o objeto de estudo. Tanto a abordagem quanto o tipo de pesquisa são justificados devido o objetivo de se buscar maior entendimento acerca do problema de pesquisa, afim de se obter maior conhecimento dos aspectos relacionados a sentimentos, 
pensamentos, intenções e comportamentos (AAKER; KUMAR; DAY, 2004; GIL, 2008).

\section{1 \\ Coleta de Dados}

Segundo Thompson, Locander e Pollio (1989), há diferentes visões epistemológicas viáveis para explorar as experiências humanas e a fenomenologia existencial é apenas uma delas. Três pressupostos descrevem a fenomenologia existencial:

- É uma ciência descritiva concentrada na vida de um indivíduo que, ao invés de separá-lo do meio ambiente e/ou da interação entre os dois, ela descreve a experiência do ser humano em sua totalidade (HEIDEGGER, 1962).

- Um evento específico pode proporcionar diferentes experiências, dependendo dos aspectos do contexto e da perspectiva de vista (VALLE; KING, 1978).

- Descreve as experiências humanas como refletidas e não refletidas (POLLIO, 1982) ou seja, fenomenólogos colocam as dificuldades dos indivíduos na vida presente e não através de um mecanismo inconsciente determinado por antecedentes históricos (MAY; YALOM, 1984).

A fenomenologia existencial afirma que a experiência pode ser vista como um padrão que surge a partir de um contexto, em que experiência e mundo não se separam, sendo vistos como constituintes (THOMPSON; LOCANDER; POLLIO, 1989). Um estudo similar ao desta dissertação foi realizado por Thompson e Üstüner (2015), em que os autores realizam entrevistas fenomenológicas para pesquisar sobre o choque dos papéis de gênero através de um determinado esporte, dentro da sociedade americana.

Seguindo modelo parecido com o dos autores, a abordagem da coleta de dados foi realizada a partir de entrevistas fenomenológicas, não estruturadas. Esta abordagem, além de incentivar o entrevistado a falar abertamente sobre o assunto de interesse, deixa claro o propósito da pesquisa (MALHOTRA, 2011).

De acordo com Samara e Barros (2006), definem-se os entrevistados como uma parte do universo a ser estudado, e que mantém as mesmas características deste universo. Porém, funcionalmente equivalente à amostragem representativa e de estrutura diferenciada, propõe-se neste estudo a "construção de um corpus" como princípio alternativo na coleta de dados, ou seja, a escolha sistemática de um 
racional para garantir maior eficiência na seleção do material a fim de caracterizar o todo (BAUER; AARTS, 2008). Este corpus é uma seleção finita de materiais relevantes - com apenas um foco temático -, homogêneo - imagens não devem ser misturadas com materiais textuais, por exemplo - e em sincronia - devem ser escolhidos dentro de um ciclo natural (BARTHES, 2009). O tamanho do corpus leva em consideração - entre outras observações - o tempo disponível para realização e análise das entrevistas (BAUER; AARTS, 2008).

Baseado nisso, o construção do corpus desta pesquisa foi formado por indivíduos que, necessariamente, praticam CrossFit, possuem Instagram - e, portanto, estão expostos diariamente a imagens divulgadas na rede -, e postam fotos da atividade esportiva. Com base na definição da construção do corpus, o método utilizado para a seleção dos entrevistados foi a técnica não probabilística por conveniência, definida como a técnica na qual os entrevistados são selecionados de acordo com a conveniência do pesquisador (SAMARA; BARROS, 2006).

O Instagram foi escolhido para esta pesquisa pois é a rede social que mais cresce no Brasil (AUDREI, 2016), com uma base de usuários em crescimento de 1 milhão/mês, em média (TOZETTO, 2017), além de ser a plataforma com maior crescimento no mercado (LUNDEN, 2014; RICHTER, 2017).

\subsection{1 \\ Entrevistas}

\subsubsection{1}

\section{Seleção de Entrevistados - Pré-entrevistas}

As entrevistas foram feitas apenas com mulheres atletas, pois segundo BUTTS (2008), LEBEL e DANYLCHUCK (2012), elas têm maior consciência de imagem ao usar as mídias sociais que, por sua vez, é base fundamental para este estudo.

Para que este estudo fosse viável, era preciso, primeiramente, encontrar mulheres que praticassem crossfit, tivessem uma conta no Instagram e, principalmente, que houvessem descoberto e se interessado pela atividade física a partir da rede social. Estas entrevistadas foram selecionadas a partir de uma pesquisa prévia realizada com mulheres praticantes de CrossFit e ativas no Instagram. Elas foram buscadas dentro do próprio aplicativo e mensagens individuais foram enviadas com uma rápida apresentação do entrevistador. 
Algumas mulheres encontradas para essa pré-entrevista indicaram amigas que também possuem Instagram, o que ajudou a aumentar o número de pré-entrevistas. Sabendo que nem todas as entrevistadas veriam e/ou responderiam as mensagens, em média 70 mensagens foram enviadas, com retorno de 33. Assim que havia uma resposta, a entrevista prévia - conduzida como um bate-papo - se iniciava com o objetivo de encontrar mulheres que tomaram conhecimento da modalidade esportiva através de fotos divulgadas por terceiros nas mídias sociais e, então, decidiram realizar e experimentar o esporte. Destas 33 entrevistas prévias, 25 tomaram conhecimento da atividade através das mídias.

\subsubsection{2}

\section{Entrevistas Fenomenológicas}

A partir do agrupamento destas 25 pré-entrevistas, foram realizadas um total de 10 entrevistas individuais de caráter fenomenológico, com mulheres residentes na cidade do Rio de Janeiro, idades entre 18 e 39 anos, necessariamente praticantes de CrossFit, possuidoras de, ao menos, uma conta ativa no Instagram, e que tomaram conhecimento do esporte a partir de imagens vistas em redes sociais. O intervalo de idade das atletas foi definido a partir do estudo de Sprey et al. (2016), citado no item 2.5.1 O Crossfit no Brasil, e o número de entrevistas foi definido por saturação, pois a partir da $8^{\mathrm{a}}$ e $9^{\mathrm{a}}$ entrevistas, começou a haver repetição de informações.

As entrevistas tiveram duração média de 40 minutos, e foram gravadas e transcritas posteriormente, com consentimento das entrevistadas. As entrevistas buscavam descobrir questões ocultas que outrora não seriam compartilhadas em uma entrevista de grupo. Para isto, a sondagem substancial foi utilizada, em busca de uma resposta mais profunda do comportamento dos entrevistados. Entrevistas em profundidade são empregadas em diferentes situações, dentre elas aquelas em que há muitas normas sociais e o entrevistado pode ser influenciado pelas respostas do grupo, ou quando se deseja obter compreensão detalhada de um comportamento (MALHOTRA, 2011). As respondentes foram informadas sobre o propósito do estudo e asseguradas de seu anonimato. 
A Tabela 2 evidencia o perfil das entrevistadas:

\begin{tabular}{|c|c|c|c|}
\hline ENTREVISTADA & SEXO & IDADE & $\begin{array}{c}\text { DURAÇÃO DA } \\
\text { ENTREVISTA }\end{array}$ \\
\hline 1 & F & 22 anos & $00: 51$ \\
\hline 2 & F & 34 anos & $00: 39$ \\
\hline 3 & F & 25 anos & $00: 26$ \\
\hline 4 & F & 28 anos & $00: 35$ \\
\hline 5 & F & 28 anos & $00: 35$ \\
\hline 6 & F & 31 anos & $00: 39$ \\
\hline 7 & F & 30 anos & $00: 33$ \\
\hline 8 & F & 33 anos & $00: 53$ \\
\hline 9 & F & 32 anos & $00: 47$ \\
\hline 10 & F & 31 anos & $00: 32$ \\
\hline
\end{tabular}

Tabela 2: Perfil das Entrevistadas

Seguindo os passos da entrevista fenomenológica (THOMPSON; LOCANDER; POLLIO, 1989), o diálogo foi todo ditado pela própria entrevistada, com a exceção de um questionamento inicial feito pelo entrevistador: "me fale um pouco sobre como você tomou conhecimento do crossfit". Ainda, o diálogo foi totalmente circular, com inserções feitas de acordo com a direção da entrevista, ao invés de predeterminadas.

Durante as entrevistas, as mulheres foram estimuladas a falar sobre suas experiências, primeiramente relacionadas ao Instagram, com perguntas como "você poderia me falar um pouco sobre o que é o Instagram pra você?", assim como indagações mais específicas relacionadas a esportes em geral e ao CrossFit como "o que significa fazer esporte pra você?", "você poderia me falar um pouco sobre o crossfit?", "você poderia me contar um pouco sobre o primeiro dia em que você viu uma foto de alguém fazendo CrossFit?".

A partir das respostas, algumas novas perguntas eram realizadas para dar continuidade ao diálogo como "quando foi a última vez que você postou uma foto no Instagram?”, "me conte um pouco sobre o primeiro dia em que você foi fazer uma aula de CrossFit", a fim de conseguir informações que pudessem indicar as razões pelas quais as mulheres incorporam o modismo "CrossFit" às suas identidades.

Após a coleta de dados, a fim de analisar as entrevistas, empreendeu-se a técnica de análise de conteúdo. 


\section{2 \\ Tratamento de Dados}

A análise qualitativa dos dados seguiu metodologia utilizada em outros trabalhos semelhantes que envolviam entrevistas fenomenológicas e não estruturadas (PETRESCU; LAUER, 2017; THOMPSON; ÜSTÜNER, 2015; SILVERMANN, 1993). Os dados coletados nas entrevistas foram tratados através da análise de conteúdo, técnica utilizada para fazer inferências a partir de textos ou transcrições dentro do contexto em que estão inseridos (KRIPPENDORFF, 2004), e utilizada para tratar dados provenientes de entrevistas fenomenológicas, como feita de forma semelhante por Thompson e Üstüner (2015). Este método para o tratamento de dados é mais do que um processo de contagem, visto que seu objetivo é relacionar os resultados obtidos com o contexto ou ambiente dentro do qual foram produzidos, e descrever e quantificar um fenômeno específico (DOWNE-WAMBOLDT, 1992). Neste caso, portanto, é a melhor alternativa para estudar valores, opiniões, atitudes e crenças, através dos dados qualitativos coletados. Foi realizada uma análise de conteúdo latente, de cunho interpretativo, em busca de significados subjacentes àqueles falados e descritos nos textos (BERG, 2011; DOWNE-WAMBOLDT, 1992). Termos e expressões similares entre as entrevistadas, assim como argumentos importantes e condizentes com o referencial desta pesquisa, foram sublinhados no decorrer da leitura das transcrições para que a condução da análise em etapas fosse iniciada.

A condução da análise se deu através de diferentes etapas, que seguiram a técnica proposta por Bardin (2011), visto que é a obra mais citada em estudos qualitativos na área de Administração. Entretanto, ressalta-se que outros autores também propõem outras formas de análise de conteúdo semelhantes, mas se seguidas com rigor, também conduzirão a resultados confiáveis e precisos.

Devido o estudo ser caracterizado como exploratório, não havia categorias estruturadas definidas anteriormente e, deste modo, a elaboração das mesmas emergiam ao longo do estudo, de forma latente, a partir dos termos sublinhados.

As etapas foram organizadas em três fases: pré-análise, exploração do material e tratamento dos resultados, inferência e interpretação. 


\subsection{1 \\ Pré Análise}

Nesta fase, as ideias iniciais foram sistematizadas através de uma leitura geral da literatura e organização das entrevistas coletadas. Aqui, foram estabelecidos indicadores para a interpretação das informações. Foi realizada uma leitura flutuante, para primeiro contato com todo o material e percepção das mensagens neles contidas, a fim de ter "impressões, representações, emoções, conhecimentos e expectativas" (FRANCO, 2008, p.52) e escolher os dados a serem analisados. Algumas regras foram seguidas (BARDIN, 2011):

- Exaustividade: nenhum elemento da pesquisa foi deixado de fora. Foram considerados todos os componentes constitutivos do corpus.

- Representatividade: como as entrevistas contém um número muito elevado de dados, quando necessário foi realizada uma amostra representativa do universo inicial (BARDIN, 2011).

- Homogeneidade: as entrevistas são homogêneas, com um mesmo tema central, sem apresentar demasiada singularidade fora do contexto.

- Pertinência: regra intimamente ligada à homogeneidade, em que os documentos devem se adequar enquanto fonte de informação, correspondendo ao objetivo que suscita a análise.

\subsection{2}

\section{Exploração do Material}

Durante a exploração do material, as categorias geradas inicialmente pelo referencial teórico bem como pelo confronto com os dados coletados foram analisadas. Nesta fase, foram construídas as operações de codificação, considerando os recortes das transcrições em unidades de registro e classificação e junção de informações em categorias simbólicas e/ou temáticas. As "unidades de registro" são partes menores do conteúdo total, registradas a partir das categorias levantadas (FRANCO, 2008). Estas unidades são parágrafos das entrevistas, dentro dos quais palavras-chaves são identificadas, e um resumo de cada parágrafo é feito para que seja realizada uma primeira categorização (BARDIN, 2011). Os códigos facilitam a identificação dos conceitos em torno dos dados, e podem ser gerados de forma dedutiva, ou seja, criados antes do processo de análise ser iniciado, ou indutiva e, portanto, modificados durante o processo de estudo (DOWNE- 
WAMBOLDT, 1992). Neste caso, os códigos foram criados no decorrer da análise e leitura dos textos, sendo, algumas vezes, modificados para melhor estruturar o estudo. Assim, a transcrição das entrevistas é recortada em unidades de registro, dentre elas palavras, frases e parágrafos, agrupadas em temas para formar as categorias iniciais, que por sua vez originam as intermediárias e, estas últimas, mais uma vez aglutinadas, resultam nas categorias finais, as quais possibilitam as inferências (BARDIN, 2011). Através deste processo indutivo, procura-se compreender o sentido da fala dos entrevistados e buscar significações ou outras mensagens através ou junto da primeira mensagem (FOSSÁ, 2003).

Para a criação das categorias, seguiram-se regras para que ocorresse posteriormente uma análise coerente:

- As categorias criadas neste estudo são distintas, mutuamente excludentes, em que nenhuma unidade de análise se encaixa em duas ou mais categorias (BARDIN, 2011; KRIPPENDORFF, 2004).

- Foram criadas categorias estritas - para não abarcar conteúdos muito amplos em uma mesma categoria - e homogêneas - com conteúdos próximos, similares (BAILEY, 1994; BARDIN, 2011).

- Em condições normais, as falas dos entrevistados têm um tema central e, muitas vezes, tema secundário (KRIPPENDORFF, 2004). Hipoteticamente falando, um entrevistado pode falar da atividade física em si e os exercícios nela exercidos, e aproveitar para complementar com opiniões de amigos. Neste exemplo, há uma dúvida se a fala será classificada em "exercícios realizados no crossfit" ou "visão de terceiros acerca da atividade". A solução é criação de uma secunda variável, ou seja, tema secundário (KRIPPENDORFF, 2004).

- Durante o processo de análise das entrevistas, foi necessário criar categorias latentes, visto que alguns dados não se encaixavam nas categorias já préaplicadas. Neste caso, para manter a confiabilidade do trabalho, todo o conteúdo classificado anteriormente era reavaliado e reajustado, se necessário (BAILEY, 1994).

\subsection{3}

\section{Tratamento dos Relatos e Discussão}

Nesta etapa, os temas, categorias e subcategorias já foram identificados e/ou modificados, e trechos relevantes da transcrição foram encaixados nestas 
categorias, com cuidado para que um mesmo dado não caísse em mais de uma categoria/subcategoria (PATTON, 2002). Muitas categorias que surgiram ainda no início foram reduzidas e adequadas à estrutura de forma uniforme, conforme decorria a análise (BURNARD, 1991).

Os conteúdos manifestos e latentes contidos em todo o material coletado foram separados e deu-se início a uma análise comparativa, ressaltando aspectos semelhantes e diferentes no estudo.

Ainda, com as categorias nomeadas e trechos devidamente relacionados, a análise foi realizada de forma latente (BURNARD, 1991), ou seja, com imersão total, a fim de identificar significados subjacentes e ocultos nas transcrições.

Para ilustrar a sequência de passos previstos no tratamento dos dados, segue esquema criado por Bardin (2011): 


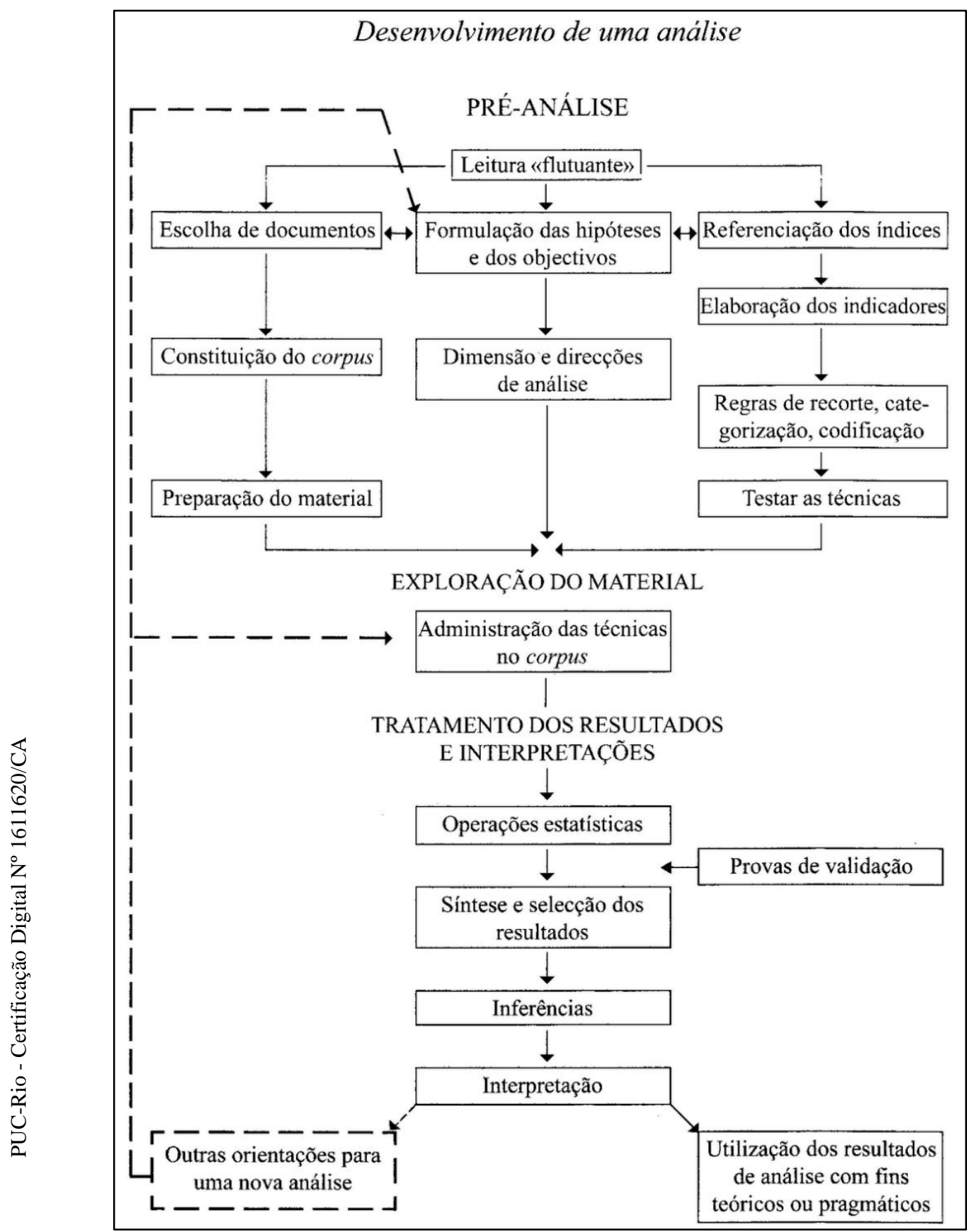

Figura 3: Desenvolvimento da análise de conteúdo Fonte: Bardin (1977)

\section{3}

\section{Limitações do Método}

Os dados coletados nas entrevistas foram provenientes apenas de fontes localizadas no Rio de Janeiro, devido proximidade com o pesquisador, o que impõe uma visão mais limitada à pesquisa.

Destaca-se também que a análise de conteúdo, enquanto conjunto de técnicas de análise de comunicações, sofreu algumas reformulações desde o seu surgimento. 
Atualmente pode-se realizar esta análise com o uso do computador, através de softwares que auxiliam, majoritariamente, na organização do material e codificação dos dados encontrados. Nesta pesquisa, toda a análise foi feita manualmente. 


\section{4 \\ Apresentação e Análise dos Resultados}

\section{1}

\section{Análise do Conteúdo}

O processo de formação das categorias se deu a partir da forma prevista por Bardin (2011), citada anteriormente, na qual após seleção do material e leitura flutuante, a exploração foi realizada através da codificação - desmembramento do texto em categorias agrupadas analogicamente. Esta codificação foi feita através do encontro de palavras e termos semelhantes e/ou repetidos, que uma vez triangulados com os resultados, foram constituindo-se em unidades de registro, para então efetuar a categorização progressiva.

A análise dos dados resultou assim nas categorias iniciais: visualização de muitos praticantes; a força da divulgação online; o boom do crossfit; o esporte da moda; amigos e comentários positivos; quantidade de amigos que praticam o esporte; sensação de pertencimento; identificação de trejeitos, gírias e roupas; comparação com midiáticos; ilusão física e autoestima; mudança corporal e autoestima; esporte, comprometimento e fitness; comunicação e integração; amizades do esporte; autoestima e exibicionismo; fotos, inovação e superação de metas; autoconfiança e tarefas pessoais; auto desafio e superação; categorias intermediárias: disseminação e divulgação online; crescimento desenfreado; incentivo de amigos; identidade; socialização e comunicabilidade; exibicionismo; autoconfiança; e por fim nas categorias finais: modismo; identidade social; mídias sociais, exibicionismo e autoestima. Tais categorias podem ser melhor visualizadas na Tabela 3. 


\begin{tabular}{|c|c|c|}
\hline CATEGORIAS INICIAIS & CATEGORIAS INTERMEDIÁRIAS & CATEGORIAS FINAIS \\
\hline $\begin{array}{l}\text { 1. Visualização de muitos } \\
\text { praticantes }\end{array}$ & \multirow{2}{*}{$\begin{array}{l}\text { I. Disseminação e divulgação } \\
\text { online }\end{array}$} & \multirow{4}{*}{ I. MODISMO } \\
\hline 2. A força da divulgação online & & \\
\hline 3. O boom do crossfit & \multirow{2}{*}{ II. Crescimento desenfreado } & \\
\hline 4. O esporte da moda & & \\
\hline $\begin{array}{l}\text { 5. Amigos e comentários } \\
\text { positivos }\end{array}$ & \multirow{2}{*}{ III. Incentivo de amigos } & \multirow{10}{*}{$\begin{array}{l}\text { II. IDENTIDADE } \\
\text { SOCIAL }\end{array}$} \\
\hline $\begin{array}{l}\text { 6. Quantidade de amigos que } \\
\text { praticam o esporte }\end{array}$ & & \\
\hline 7. Sensação de pertencimento & \multirow{6}{*}{ IV. Identidade } & \\
\hline $\begin{array}{l}\text { 8. Identificação de trejeitos, } \\
\text { gírias e roupas }\end{array}$ & & \\
\hline 9. Comparações com midiáticos & & \\
\hline 10. Ilusão física e autoestima & & \\
\hline $\begin{array}{l}\text { 11. Mudança corporal e } \\
\text { autoestima }\end{array}$ & & \\
\hline $\begin{array}{l}\text { 12. Esporte, comprometimento e } \\
\text { fitness }\end{array}$ & & \\
\hline 13. Comunicação e integração & \multirow{2}{*}{$\begin{array}{l}\text { V. Socialização e } \\
\text { comunicabilidade }\end{array}$} & \\
\hline 14. Amizades do esporte & & \\
\hline 15. Autoestima e exibicionismo & \multirow[b]{2}{*}{ VI. Exibicionismo } & \multirow{4}{*}{$\begin{array}{l}\text { III. MÍDIAS SOCIAIS, } \\
\text { EXIBICIONISMO E } \\
\text { AUTOESTIMA }\end{array}$} \\
\hline $\begin{array}{l}\text { 16. Fotos, inovação e superação } \\
\text { de metas }\end{array}$ & & \\
\hline $\begin{array}{l}\text { 17. Autoconfiança e tarefas } \\
\text { pessoais }\end{array}$ & \multirow[t]{2}{*}{ VII. Autoconfiança } & \\
\hline 18. Auto desafio e superação & & \\
\hline
\end{tabular}

Tabela 3: Categorias de Análise

\section{2}

\section{Categorias de Análise}

A análise teve início por meio da categorização, aglutinadas por similaridade de conteúdo, elaborando-se assim, as categorias iniciais. A partir deste ponto, seguindo o mesmo modelo e à medida que se entrelaçavam as cadeias de significações, surgiram então as categorias intermediárias como suporte para as categorias finais. As mesmas serão apresentadas nos pontos 4.2.2 e 4.2.3.

\subsection{1}

\section{Categorias Iniciais}

As categorias iniciais caracterizam-se como as primeiras impressões referentes à realidade estudada e não há regras para a nomeação e/ou quantidade das mesmas, surgindo a partir de trechos selecionados das entrevistas, e também contam com respaldo do referencial teórico (BARDIN, 2011). Deste processo de categorização 
das entrevistas transcritas, resultaram em vinte e sete categorias iniciais, que foram pontos chaves de suporte às categorias seguintes, intermediárias. Cada categoria conta com trechos selecionados das falas dos entrevistados assim como respaldo teórico.

\subsubsection{1}

\section{Visualização de Muitos Praticantes}

A primeira categoria inicial diz respeito à quantidade de indivíduos que praticam crossfit, fazendo alusão, principalmente, à divulgação indireta ao não praticante. Pessoas que não conhecem o esporte e não possuem nenhum contato com ele, acabam, sem querer, vendo muitas pessoas comentando sobre o assunto, e/ou, muitas vezes, indo para os treinos. Uma forma muito comum de contato visual com estes praticantes é nas próprias ruas, visto que as "boxes", normalmente, ficam de portas abertas para as calçadas, o que faz com que todos que passam em frente, vejam os treinos.

Para ilustrar a categoria, seguem duas falas de entrevistadas:

\footnotetext{
$\mathrm{Vi}$ as pessoas indo, as boxes começando a encher e pensei: por que não experimentar? (...) Em diferentes ruas tinham boxes abertas e eu via as pessoas fazendo (entrevistada 1 ).

Então, eles (conhecidos) começaram a fazer e só falavam disso. Eu os via indo treinar, então falei com eles e eles me falaram mais ou menos como era o estilo dos treinos e achavam que eu ia gostar, porque gosto de coisas diferentes (entrevistada 9).
}

As falas dos entrevistados entram em consonância com os postulados de Banerjee (2010), Hass (1981) e Chaiken (1979). O comportamento coletivo tem base nas informações que o indivíduo recebe a respeito dos valores dos serviços (neste caso, do crossfit) e, mesmo com a informação incompleta (e, muitas vezes, apenas visuais), acaba por tomar decisões e definir valores através da tomada de decisão de outros indivíduos que já usufruem do serviço (BANERJEE, 2010). Neste caso, o envolvimento pessoal do indivíduo em relação ao crossfit ainda é baixo e a persuasão ocorre através de "pistas periféricas" (HASS, 1981) e atratividade do esporte (CHAIKEN, 1979). Ainda, estas pistas surgem a partir da representação da credibilidade e atratividade das fontes, proximidade física e número de pessoas que defendem o contrário (NOWAK; SZAMREJ; LATANÉ, 1990). 


\subsubsection{2}

\section{A Força da Divulgação Online}

Esta categoria refere-se à prática do crossfit por muitas pessoas e que fazem divulgação online através de postagens nas redes sociais, dentre elas, upload de fotos durante os treinos, matérias à respeito do esporte, vídeos, entrevistas e/ou qualquer conteúdo relacionado ao crossfit. Atualmente, uma forma muito comum de visualização de postagens e, consequentemente, disseminação do esporte, é através do Instagram e Facebook, em que amigos e conhecidos divulgam online suas atividades diárias.

As falas das entrevistadas abaixo demonstram essa disseminação do esporte através da divulgação online:

Fiquei sabendo pela internet mesmo. Amigos e conhecidos postando e começando a fazer (...). Postagem de fotos, matérias (...). Vi que a galera estava curtindo, cada vez mais gente fazendo (...) e não resisti. Tive que entrar (entrevistada 5).

Um dia qualquer, sei lá quando, vi uma foto de um amigo no meu instagram, levantando peso, subindo corda e tal. Algumas fotos...E com o tempo, muitas fotos foram surgindo no meu instagram e também no facebook de outras pessoas (...). Não só fotos né..Tinha de tudo (entrevistada 6).

Os relatos das entrevistadas acima evidenciam a força da divulgação online de fotos, matérias e vídeos, que tornam o crossfit um esporte conhecido. Segundo Kindberg et al. (2005), dois terços das imagens capturadas por usuários de redes sociais têm como propósito final o compartilhamento de fotos. O Instagram é a rede mais utilizada para compartilhar fotos, repassando para outras redes após postagem, como Facebook (HU; MANIKONDA; KAMBHAMPATI, 2014), o que torna estas plataformas formas de correntes de consciência social (NAAMAN; BOASE; LAI, 2010).

\subsubsection{3}

\section{O Boom do Crossfit}

O boom do crossfit é outra característica muito citada pelas entrevistadas. Durante as primeiras aparições do esporte, muitas pessoas começaram a praticar e a cada vez mais divulgar online e offline. Segundo Beers (2014), o crossfit atingiu 10 mil afiliados em 2014, em todo o mundo. Em pouco tempo, a modalidade se 
transformou em uma das maiores tendências no mercado esportivo (DAWSON, 2017).

Comecei em uma época que ainda era o boom do crossfit. (...) Quando comecei, tinha muita gente conhecida fazendo e eu não via muita gente fazendo outros esportes. Minha timeline só 'dava' crossfit (entrevistada $3)$.

So no Brasil, em 2016, o crossfit atingiu 40 mil afiliados, espalhados por 440 centros certificados (SPREY et al., 2016), o que explica este crescimento rápido em tão pouco tempo.

\subsubsection{4 \\ O Esporte da Moda}

A quarta categoria inicial se refere às situações sociais que influenciam o comportamento de terceiros. Inúmeras vezes indivíduos tomam decisões a partir do que amigos e/ou conhecidos estão fazendo, seja para escolher um restaurante, tomar uma bebida ou praticar um esporte.

A entrevistada 4 fala um pouco deste "contágio" relacionado às ações e tomadas de decisão:

\footnotetext{
$\mathrm{Na}$ época em que eu comecei, era uma coisa relativamente nova, com muita gente entrando e fazendo (...). Literalmente moda. (...) Eu achava que não era pra mim, que era coisa de maluco. Via as pessoas fazendo em praças e tal, e ficava pensando que eu nunca ia fazer aquilo, que era ridículo...Se não fosse essa divulgação toda do crossfit, eu certamente não teria entrado (entrevistada 4).
}

$\mathrm{Na}$ fala da entrevistada 4, identificam-se traços claros de imitação, principalmente quando ela diz que o esporte era "literalmente moda" e cita sua desaprovação inicial. Segundo Simmel (1957), a imitação é a transferência, para terceiros, da responsabilidade pela ação realizada. Ou seja, o indivíduo não precisa se preocupar com a escolha de suas ações, surgindo apenas como uma pessoa a mais dentro de um grupo dotado de conteúdos sociais (SIMMEL, 1957).

Ainda, aproveitando a parte em que a entrevistada diz que achava que o esporte não era para ela, que era "coisa de maluco", "ridículo" e que nunca praticaria crossfit, pode-se traçar um paralelo com Aguirre, Quarantelli e Mendoza (1988) que afirmam que dentro do comportamento coletivo, dentre outras características, está a estranheza, ou seja, a desaprovação por aqueles que não aderem à moda. A entrevistada, inicialmente, quando ainda não era praticante, desaprovava a moda e tinha repulsa por quem a aderia. Até que decidiu entrar e experimentar o esporte. 


\title{
4.2.1.5 \\ Amigos e Comentários Positivos
}

A presente categoria faz referência às formas de incentivo preconizadas pelos praticantes de crossfit. Estes, entusiasmados com a nova modalidade, comentam entre si e com os não praticantes sobre as atividades realizadas nos treinos, além de chamarem estes últimos para realizarem treinos experimentais.

\begin{abstract}
Comecei pulando corda. Postava algumas fotos e tal e algumas amigas sempre viam (as fotos) e comentavam do crossfit. Elas faziam e viviam postando também. No crossfit a gente pula corda, sobe corda, escala parede, levanta peso. Tem de tudo. Cada dia uma coisa diferente. Algo que não se consegue com qualquer esporte. Então essas amigas comentaram sobre o esporte. Resolvi entrar (entrevistada 2).
\end{abstract}

Eu fiz muaythai por um tempo. Aí depois, meu amigo que treinava crossfit no Leblon me falou que começou a fazer (...). Eu nunca gostei de academia, essas coisas assim...então musculação para mim nunca deu certo. Sempre fui aquela pessoa que pagava seis meses e ía dois. (entrevistada 1).

Ah, me interessei porque é uma parada dinâmica né? O tempo passa rápido, é bem motivador e é super intenso...Queria sair da mesmice da academia. Não aguentava mais (entrevistada 5).

É interessante notar a conexão com a afirmação de Allisson Belger (2012). Segundo o autor, tanto a conexão social - ou seja, a interação entre os praticantes e não praticantes - quanto o senso de comunidade - muito relacionado com a sensação de equipe dentro das boxes - são indispensáveis para disseminar os princípios e metodologias do crossfit, aumentando sua popularidade.

Ainda, outra forma de incentivo muito comum é citar para os que não são praticantes quais atividades são realizadas nos treinos de crossfit. Os mais atingidos por esses comentários positivos são aqueles que costumam achar os treinos de academias monótonos e rotineiros, e que se sentem atraídos, então, pela rotina de treino dinâmica do crossfit (HERZ, 2014; SPREY et al., 2016). Comentários como: "Tem de tudo. Cada dia uma coisa diferente. Algo que não se consegue em qualquer esporte" (entrevistada 2); "Eu nunca gostei de academia (...), então musculação para mim nunca deu certo" (entrevistada 1); "Queria sair da mesmice da academia. Não aguentava mais" (entrevistada 5) provam as afirmações de Herz (2014) e Sprey et al. (2016). 


\subsubsection{6 \\ Quantidade de Amigos que Praticam o Esporte}

Independente das pessoas falarem ou não do crossfit, realizarem comentários positivos ou não, muitas vezes, sem nem saber muito sobre o assunto, nota-se muitos conhecidos/amigos praticando uma atividade em comum, o que desperta a curiosidade do não praticante. Ainda, quanto mais pessoas pertencentes a um grupo de amigos fazem a mesma atividade, maior a probabilidade de outros deste mesmo grupo seguirem a mesma atividade. Um exemplo disto é a afirmação abaixo:

Eu queria fazer algum esporte. Não sabia qual ainda. Cheguei a ver diferentes lutas, funcional na praia e tal. Mas com amigas e amigos fazendo crossfit e falando o tempo todo entre eles sobre a atividade, fiquei curiosa e acabei escolhendo pelo crossfit mesmo (entrevistada 2).

Esta afirmação pode ser corroborada por Burt (1987), a partir da ideia de que algumas pessoas buscam orientações indiretas quando não sabem para que direção determinar suas escolhas, acabando por se envolver, então, em um processo de imitação, em busca de comportamentos sociais que se adequem, de alguma forma, aos seus.

\subsubsection{7}

\section{Sensação de Pertencimento}

Sentir-se parte integrante de um grupo, é outra das muitas características dos praticantes de crossfit. Segundo McKenzie (2013), as interações sociais têm ocorrido além dos ambientes pessoais e de trabalho, estendendo-se para as academias, que se tornaram locais significativos para a troca de ideias e interesses mútuos. Ainda segundo o autor, essa interação aumenta o senso de pertencimento.

O que eu gosto muito no crossfit são as pessoas. Como eu vou muito, sempre no mesmo horário, tem sempre a mesma turma. E a gente ficou muito amigo. Então, além de ver as pessoas todos os dias porque eu faço crossfit de segunda a sábado, a gente ainda se encontra à noite, várias vezes. Então foi meio que criando uma família. O crossfit é mais do que um esporte. Tem a ver com família, amigos, estilo de vida (entrevistada 10).

$\mathrm{Na}$ afirmação da entrevistada 10, pode-se confirmar essa sensação de pertencimento, principalmente quando ela afirma que "Então foi meio que criando uma família. O crossfit é mais que um esporte. Tem a ver com família, amigos, estilo de vida". 
Só sai(o) com amigos novos do crossfit. Para mim, tem um fator incrível que é a sensação de comunidade (...) Tenho grandes amigos, namoro há 4 anos e conheci meu namorado no crossfit (entrevistada 4).

Mudou muito meu círculo de amizades. (...) O povo se acolhe, combina de sair e quando vi, já tinha amigos próximos, de ir na casa deles, marcar viagens juntos, barzinho, cinema..(entrevistada 9).

Segundo Glassman (2004), o crossfit é uma comunidade, que impede seus participantes de serem pessoas autônomas e anônimas, visto que os treinos em grupo requerem forte interação entre os praticantes (GLASSMAN, 2011).

\title{
4.2.1.8 \\ Identificação de Trejeitos, Gírias e Roupas
}

Esta sensação de comunidade (GLASSMAN, 2004) citada na categoria anterior é apenas uma das características do crossfit. Outra situação muito comentada é a identificação com a forma de falar, de agir e até de se vestir, que naturalmente ocorre a partir dessa sensação de pertencimento a um grupo.

\begin{abstract}
Vivem falando besteira, são super descolados e animados. Eu não sou uma pessoa muito fresca, sabe? E ai o crossfit foi um esporte que me identifiquei. (...) Gosto de falar do esporte, do que estou fazendo, quanto peso estou pegando (...). Minhas amigos que não são do crossfit são muito cheias de frescuras (...) dizem que pareço homem, que eu devia ser mais feminina. (...) Quando saio com a galera do crossfit, o papo voa, ficamos horas falando, nos zoando. Até o vocabulário nosso muda. (entrevistada 3).
\end{abstract}

Tem gente que passa a sair com o tênis do crossfit, sainhas curtinhas, blusinhas aparecendo a barriga... Porque o corpo fica mais bonito né? (entrevistada 7).

Há uma linguagem própria adquirida e compartilhada no crossfit, caracterizada, principalmente, pelo desenvolvimento dos nomes específicos dos WODS, que apenas os praticantes do esporte conseguem entender, além de gírias e trejeitos (HERZ, 2014). Identificam-se estes fatos, quando a entrevistada 3 afirma que "minhas amigas que não são do crossfit são muito cheias de frescuras (...), dizem que pareço homem (...). Quando saio com a galera do crossfit, o papo voa, ficamos horas (...) nos zoando. Até o vocabulário muda".

Pode-se notar também que pertencer a esta comunidade faz com que os praticantes do esporte adaptem, inclusive, suas formas de se vestir. A entrevistada 7 exemplifica este fato, que vai de encontro com o que Herz (2014) afirma: que dentro do crossfit há uma tendência dos praticantes vestirem roupas similares, e que as 
mulheres podem ser identificadas através destes "uniformes" que utilizam para treinar e, as vezes, até para sair.

\subsubsection{9}

\section{Comparação com Midiáticos}

Na categoria inicial de número nove, o praticante compara seus próprios corpos e treinos com àqueles de atletas profissionais da mídia.

\footnotetext{
O open é um campeonato online. Então é muito legal porque eu estou fazendo a mesma prova que a campeã mundial! (entrevistada 1)

(...) Agora que faço crossfit, comecei a assistir competições de crossfit na TV, ou até ir em campeonatos. Meio que criou um universo novo que eu não tinha (...). Mudaram meus interesses. Coisas que eu não fazia antes, eu passei a fazer. Passei a me comparar mais. Ver se os exercícios que passavam na TV eram os mesmos que eu estava fazendo e tal...(entrevistada 10)
}

Esta comparação com midiáticos é comentada por Cohen e Colin (2014), Markula (1995) e Rinkunas (2011). O crossfit passa a representar muito mais do que um esporte, se transformando em um meio de alcançar corpo e performance ideais, cultivados pela mídia, em que para ser sexy e magra, o praticante tem que ser torneado e definido. Tudo passa a ser apenas uma representação da realidade e os praticantes do esporte se tornam fanáticos a ponto de se transformarem apenas em imagens de si mesmos, como os midiáticos que deixam transparecer nas televisões apenas identidades idealizadas (SONTAG, 2015).

\subsubsection{0 llusão Física e Autoestima}

A décima categoria inicial diz respeito ao aumento da autoestima do praticante de crossfit devido à ilusão de embelezamento do próprio corpo. Por mais que o atleta amador não tenha mudado sua forma física com os exercícios - e isso pôde ser percebido ao longo da entrevista fenomenológica -, ele tem um olhar diferente para o próprio corpo. Esta ilusão pode ser exemplificada abaixo:

Hoje em dia eu estou com 65 quilos...ou seja, 4 ou 5 quilos a mais do que eu tinha na época que eu estava me achando gordinha. E eu nunca estive mais magra na minha vida! Meu percentual de gordura está um pouco mais alto do que eu já tive no ano passado. Já ganhei uns 10 quilos de massa magra desde que comecei. (...) Mas eu fazia ginástica (antigamente) e era mais leve. Nunca estive tão satisfeita com meu corpo. (...) É ótimo se olhar no espelho e ver que eu estou na minha 
melhor forma física e isso é só o resultado de algo que amo. Hoje eu adoro o meu corpo. Estou muito satisfeita com isso e isso foi muito bom para minha autoestima (entrevista 1).

É possível identificar, claramente, a contradição na entrevista da entrevistada 1. Ela afirma que o percentual de gordura dela está mais alto atualmente - o que é um indicativo de que ela ganhou massa gorda - e que ganhou 5 quilos, porém enfatiza a satisfação com o próprio corpo e o fato de se olhar no espelho e achar que está na melhor forma física desde então.

Nota-se um aumento de autoestima devido a prática do esporte, indo diretamente de encontro com o que Cordeiro (2011) afirma em relação às modificações corporais. Segundo a autora, estas alterações físicas modificam nossas identidades e o que pensamos de nós mesmos e a reflexividade do self (GIDDENS, 1991) acaba por se estender à imagem corporal e visível.

\subsubsection{1 \\ Mudança Corporal e Autoestima}

Apesar de parecida com a categoria inicial anterior, esta categoria refere-se às modificações corporais visíveis a partir da prática do crossfit, ou seja, à indivíduos que ficam mais fortes, mais magros, ou com corpos torneados característicos de quem realiza estas atividades. Abaixo alguns trechos:

\footnotetext{
Ganhei músculo, ganhei perna, ganhei braço. Estou até ficando com quadradinhos na barriga. (...) Me sinto bem, sabe? Me sinto mais bonita, autoestima melhor (...) (entrevistada 3 ).

\begin{abstract}
Não posso dizer que não tem um significado físico porque meu corpo mudou muito...para a melhor. E eu acho bonito um corpo torneado, sabe? (...) Eu estava desestimulada com a musculação, me achando fraca e feia e fui procurar um exercício que substituísse a musculação. E o funcional sozinho não substituía (...) porque o corpo não fica igual. O corpo que eu gosto é de quem pega peso. (...) eu queria sair da musculação, mas não queria fazer só exercício aeróbico, sabe? Queria um exercício de força e aí o crossfit veio exatamente para complementar o que eu queria (entrevistada 6).
\end{abstract}

Os exemplos acima deixam clara a relação entre a autoestima e a mudança física. Nota-se um aumento da autoestima devido os resultados que o esporte proporciona no corpo. Sassatelli (2010) comenta essa transformação, afirmando que há uma troca de valores em que ao invés do indivíduo buscar uma "performance atlética", o objetivo final e preocupação estão na "performance corporificada". 
Festinger (1954) informa que, através de uma auto avaliação, os indivíduos percebem diferenças favoráveis e desfavoráveis em relação aos outros, principalmente em comparações referentes à aparência física.

Mesmo sendo visto como um esporte para aprimoramento físico (BELGER, 2012), a natureza competitiva dele faz com que os praticantes idealizem a prática com a ideia de que serão transformados na pessoa mais fit do mundo (DAWSON, 2017).

\subsubsection{2}

\section{Esporte, Comprometimento e Fitness}

A última categoria inicial diz respeito à realização do esporte com o objetivo de emagrecer e ficar em boa forma física. Boa parte dos praticantes inicia um ciclo de envolvimento grande com a atividade, aliando a melhora do condicionamento físico com um equilíbrio alimentar. Este equilíbrio alimentar ajuda tanto no desempenho dos treinos quanto no emagrecimento do atleta amador.

Hoje em dia o que me faz não comer um doce super cheio de açúcar não são as calorias, mas sim por saber o quanto isso prejudica meu treino. (entrevistada 1).

Consegui criar hábitos, cuida mais da alimentação, porque sei que se eu vacilar na alimentação, não vou ter tanto resultado (entrevistada 7).

Um único esporte alia o equilíbrio alimentar à performance e à boa forma física, exigindo comprometimento diário do atleta.

Trouxe a vontade de me alimentar bem, sabe? Essa consciência de tudo que eu coloco para dentro do meu corpo, não tanto quanto neura de se alimentar e contar calorias, mas mais por qualidade de alimentação mesmo. (entrevistada 9).

Powers e Greenwell (2016) falam sobre este comprometimento em atividades do branded fitness, que envolvem alimentos, equipamentos, adereços, serviços e mídias sociais, exigindo do atleta um forte engajamento que demanda tempo substancial e social.

Comecei a fazer o crossfit primeiro porque muitas pessoas falavam que eu era muito "magrinha" e que eu tinha uma postura ruim. Mas acho que o pior foi quando me olhei em uma foto e me achei gorda. Foi meio que a gota d'agua. Então decidi entrar no crossfit (entrevistada 3).

Eu jogava futebol com minha amiga que já fazia cross e ela dizia que era desafiador e super eficiente pra ficar em forma (...). Resolvi entrar com ela. (entrevistada 4). 
Outros autores comentam que essa transformação física é proveniente, também, das alterações nos planos alimentares e o esporte representa, portanto, uma forma de alcançar o corpo fitness idealizado nas mídias (COHEN; COLINO, 2014; RINKUNAS, 2011). A preocupação com o modo de vida fitness, que antes era voltada para o serviço militar apenas, agora busca a gestão da saúde para a prevenção de doenças, o que explica o equilíbrio alimentar e desempenho (SHILLING, 2012; MAGUIRE, 2007). Porém, Bolin e Granskog (2003) e Dworkin e Wachs (2009) comentam que, atualmente, ser fitness vai além da gestão da saúde, se assemelhando mais a sinônimo de beleza apenas.

\title{
4.2.1.13
}

\section{Comunicação e Integração}

Ao longo das entrevistas fenomenológicas, foi possível extrair das entrevistadas algumas informações valiosas acerca de características mais intrínsecas e difíceis de acessar.

\begin{abstract}
Eles (amigos e família) dizem que eu era muito fechada. (...) E o crossfit é uma comunidade muito unida. Eu acho que passei a me abrir mais. As pessoas se ajudam muito no treino. (...) Então acabei ficando bem mais comunicativa. (...) Sou muito mais aberta e muito mais feliz (entrevistada 1).

Acho que eu era muito mais na minha, sei lá, meio fechada. Ia para a academia e ficava lá malhando sem falar com ninguém. No crossfit fiz alguns amigos e amigas. Bato papo, participo de atividades em equipe. (...) Ajuda um pouco a soltar a gente, deixar a gente mais livre, sabe? (entrevistada 5).
\end{abstract}

Aqui, nota-se claramente o processo de reinvenção citado por Scott (2010). A autora afirma que há um aprimoramento pessoal atingido através das regras performativas ocorridas no contexto de interação (do crossfit). Quando a entrevistada 5 afirma que é "muito mais aberta e muito mais feliz", ela vai de encontro com a afirmação de Markula (1995) que diz que os praticantes do crossfit levam também em consideração quem eles se tornam a partir da realização da atividade.

\subsubsection{4}

\section{Amizades do Esporte}

A categoria inicial em questão elucida a criação de novos laços de amizade dentro da comunidade do crossfit. Ainda, os praticantes da atividade passam a se 
comunicar e sair quase que todo o tempo com estes novos amigos, se identificando com eles para todos os momentos. O conceito de "aprimoramento pessoal voluntário" citado por Scott (2010) se encaixa nesta categoria, visto os praticantes do crossfit buscam, mesmo que de forma inconsciente, uma transformação de identidade através da adesão ao esporte.

\begin{abstract}
Acabei conhecendo pessoas novas na 'box' que faço crossfit aqui no Leblon. (...) Fiz muitas amizades. Inclusive, eu costumo sair com esses amigos do crossfit (entrevistada 3).

$\mathrm{O}$ crossfit me deu amigos. Bons amigos. Aumentou meu leque de amizades. Tenho meu grupo de fora, conheço bastante gente. Mas hoje tenho uma penca de bons vizinhos (graças ao crossfit) (entrevistada 8).
\end{abstract}

No crossfit, os atletas não podem, nem conseguem, permanecer dentro de suas barreiras virtuais, olhando celulares, ouvindo músicas ou assistindo televisão (DAWSON, 2017). É preciso realizar as atividades em conjunto e Lalich e Langone (2006) citam a similaridade do esporte com o culto, também devido a inabilidade gradual dos participantes de se relacionarem com pessoas de fora do grupo, além do desejo de recrutar novos membros. Esta afirmação dos autores está relacionada diretamente com as falas das entrevistadas que comentam a criação de novos laços de amizade e perda de laços anteriores.

\title{
4.2.1.15
}

\section{Autoestima e Exibicionismo}

A décima quarta categoria inicial diz respeito ao aumento do exibicionismo corporal dos praticantes, através da divulgação online e/ou offline de fotos, devido mudanças corporais e aumento da autoestima. Ainda, esta categoria evidencia o contrário, ou seja, o aumento da autoestima como consequência do exibicionismo online.

\footnotetext{
Meu corpo e minha mente estão em sintonia. (Tenho) vontade de sair e mostrar meu corpo. (...) Gosto de sair com cropped e saia ou short, que mostram abdômen e perna. Antigamente vivia usando calça jeans com blusinha e tênis. Hoje em dia sou mais arrumadinha. Quero mostrar o resultado do esporte para os outros. Alguns até perguntam e eu me sinto bem falando (do crossfit), sabe? (entrevistada 3).
}

Tiro muita foto de mim mesma em casa, para perceber essas diferenças (físicas) (entrevistada 1).

Pela fala da entrevistada 3, é possível perceber nas entrelinhas o aumento da autoestima, a partir do momento em que ela decide deixar as roupas mais simples e 
menos decotadas de lado, para passar a usar roupas mais decotadas e curtas. Percebe-se, claramente, o aumento do exibicionismo corporal. Segundo Thompson e Hirschman (1995), quando o indivíduo passa a ter consciência do próprio corpo, ele busca sempre aprimorá-lo de alguma forma através de críticas em relação à aparência, transformando-o em um corpo mais desejado.

O corpo se tornou elemento de marca pessoal do consumidor, assim como uma marca em si, e o que antes eram manifestações físicas dos valores pessoais de cada um, passaram a ser potenciais "avatares" de valor de marca (POWERS; GREENWELL, 2016).

\subsubsection{6 \\ Fotos, Inovação e Superação de Metas}

Muitas vezes, as fotos divulgadas pelos participantes da atividade física estimulam o conhecimento e a curiosidade dos não praticantes. Segundo dados encontrados nas entrevistas, a ideia de superação que as fotos passam incitam o não praticante a querer conhecer o esporte.

Quando vi aquelas pessoas levantando pneu e subindo corda, pensei: "quando na vida que vou fazer isso?", "em que momento na vida eu poderia fazer algo parecido?" (entrevistada 3).

Logo pelas fotos a gente percebe (que é dinâmico, inovador). Cada dia algo diferente que a galera posta e (...) coisas que você nunca faria no seu dia a dia, sabe? Bem diferentes de qualquer coisa: mover pneu de caminhão, subir corda, levantar peso de sei lá quantos quilos. Tem muitos wods diferentes...exercícios (entrevistada 5).

Acho que ver os movimentos que as pessoas fazem, a técnica que elas usam (é muito legal). Se for vídeo, dá para ver se a pessoa já tem um tempo (fazendo o esporte) ou se está só começando (entrevistada 9).

As fotos trazem uma ideia de que (o esporte) não é impossível, que eu posso fazer também, que posso gostar também. (...) Eu sigo mil atletas né? Então, quando vejo treinos 'bizarros', tempos e pesos que a galera pega, me passa uma sensação de admiração, de inspiração (...). Quando vejo pessoas normais, ou até Instagrams de boxes normais, me chama muita a atenção os movimentos e força de vontade (...). Eu não posto muito, mas acompanho bastante (entrevistada 4).

A partir do depoimento das entrevistadas, nota-se que as fotos divulgadas incitam a curiosidade, a vontade de praticar o esporte e, ainda, mostram que é um esporte inovador, diferente de todos os outros e de possível alcance de todos. A entrevistada 3 foca, principalmente, na inovação, enquanto a entrevistada 4 fala da "sensação de 
admiração e inspiração" que as fotos passam, além da ilusão de que todos são capazes de praticar crossfit.

Dawson (2017) comenta sobre a divulgação de fotos dos praticantes e afirma que os mesmos são encorajados a divulgar tudo nas redes sociais para motivar outras pessoas. Ainda segundo o autor, para atletas amadores, este material virtual oferece uma grande via de interação além dos locais físicos de treinos, o que possibilita o conhecimento e acesso dos não praticantes a todos os exercícios, tendo, portanto, um papel critico na performance dos mesmos.

\title{
4.2.1.17
}

\section{Autoconfiança e Tarefas Pessoais}

A décima sexta categoria diz respeito ao aumento da autoconfiança devido as atividades realizadas nos treinos de crossfit. As entrevistadas alegam transferência desta autoconfiança para tarefas pessoais realizadas no dia a dia. Abaixo, seguem exemplos:

\begin{abstract}
Gosto dessa sensação de poder que o crossfit me dá. Eu me sinto mais confiante pra tudo, até para coisas do dia a dia. (...) Sinto também que consigo me proteger, sabe? Proteger minha mãe na rua, se algo acontecer. É como se eu me sentisse muito mais forte, mesmo não aparentando. (...) E essa confiança acaba se transferindo para outras atividades como trabalho e até lazer mesmo (entrevistada 3).

Eu acho que a gente acaba ficando bem metido. Tipo uma sensação que posso fazer tudo (...). Se tenho que carregar uma mochila pesada, está ok. Sei lá. Até subestimo algumas coisas (...). Acho muito legal ver os efeitos do crossfit na prática. Seja para carregar compras no mercado, pegar mala no aeroporto ou até para outros esportes mesmo (entrevistada 4).
\end{abstract}

Markula (1995), Belger (2012), Murphy (2012) e Herz (2014) comentam essa mudança na vida pessoal do dos praticantes de atividades físicas, a partir da influência dos exercícios. Quando vão decidir qual esporte escolher, os não praticantes levam em consideração quem eles se tornarão com aquela atividade, o que gera grandes mudanças de vida e alterações de perspectivas no mundo pessoal do praticante (MARKULA, 1995; BELGER, 2012; MURPHY, 2012; HERZ, 2014). 


\title{
4.2.1.18
}

\section{Auto Desafio e Superação}

Sensivelmente, porém significativamente diferente da categoria anterior, aqui as atletas amadoras continuamente se desafiam dentro das academias de crossfit e durante os treinos, seja através da realização de exercícios mais difíceis ou levantamento de barras mais pesadas, com o intuito de se auto superarem, indo além de suas próprias expectativas. E isso é algo comumente visto dentro dos esportes.

\begin{abstract}
Como eu treino há muito tempo, eu me cobro muito mais. Às vezes eu penso "eu fazia isso muito melhor antigamente" (...). Se auto desafiar no individual. É sempre um desafio muito grande e uma evolução muito grande (entrevistada 1).

(O crossfit é desafiador porque) sempre tem algo novo, algo para você melhorar, sabe? Superar e tal (entrevistada 4).

O crossfit incentiva muito a superação. Acho muito legal o fato da principal comparação ser com a própria pessoa, sabe? Comparo minha evolução comigo mesma. (...) Fico muito feliz de ver que eu estou evoluindo em relação aos limites que eu tinha antes (entrevistada 10).
\end{abstract}

Através das falas das entrevistadas, notam-se traços de auto desafio e a constante vontade em melhorar. Powers e Greenwell (2016) citam essa transformação não apenas no exercício em si, mas no desempenho do esporte na vida das pessoas. Shilling (2012) afirma que nossos corpos deixaram de ser algo comum, para se tornarem fenômenos em eterno desenvolvimento. Traçando um paralelo com Shilling (2012), é possível notar que este auto desafio e capacidade de superação são valores eternos e constantes, fazendo com que o atleta queira sempre buscar um novo limite.

\subsection{2}

\section{Categorias Intermediárias}

As sete categorias intermediárias apresentadas nesta seção surgiram, inicialmente, do agrupamento das 18 categorias iniciais. Estas últimas estão pautadas nas transcrições das entrevistas e foram reunidas, originando as categorias intermediárias: disseminação e divulgação online, crescimento desenfreado, incentivo de amigos, identidade, socialização e comunicabilidade, exibicionismo e autoconfiança. 


\subsubsection{1}

\section{Disseminação e Divulgação Online}

\begin{tabular}{|l|l|l|}
\hline \multicolumn{1}{|c|}{ CATEGORIAS INICIAIS } & \multicolumn{1}{|c|}{ CONCEITO NORTEADOR } & CATEGORIA INTERMEDIÁRIA \\
\hline $\begin{array}{l}\text { 1. Visualização de muitos } \\
\text { praticantes }\end{array}$ & $\begin{array}{l}\text { Evidencia a prática do esporte } \\
\text { por muitas pessoas e, } \\
\text { consequentemente, } \\
\text { divulgação indireta ao não } \\
\text { praticante. }\end{array}$ & \multirow{2}{*}{$\begin{array}{l}\text { I. Disseminação e } \\
\text { divulgação online }\end{array}$} \\
\cline { 1 - 2 } $\begin{array}{l}\text { 2. A força da divulgação } \\
\text { online }\end{array}$ & $\begin{array}{l}\text { Indica a prática do esporte por } \\
\text { muitas pessoas e grande } \\
\text { divulgação online de postagens } \\
\text { relacionadas ao mesmo. }\end{array}$ & \\
\hline
\end{tabular}

Tabela 4: formação da categoria intermediária: "Disseminação e divulgação online"

A categoria intermediária "disseminação e divulgação online" diz respeito à forte propagação do crossfit, que culminou em muitos praticantes e, consequentemente, uma consciência e visualização substancial do esporte pelos indivíduos não praticantes. Dado isto, a categoria também ilustra a força da divulgação online para o "conhecimento de marca" (neste caso, do crossfit) e influência de novos praticantes. A título de exemplo, a entrevistada 2 cita a influência desta divulgação e disseminação do esporte para que ela começasse a praticar:

Talvez se (eu) tivesse amigos postando (fotos de outro esporte) e fazendo em outros lugares, eu talvez tivesse escolhido outro esporte. A gente costuma muito seguir todo mundo, né? Meu primeiro contato com o crossfit foi através do Instagram. Muitas pessoas postando stories e fotos também. Aproveitei os amigos e o momento propício (amigos fazendo e crossfit em alta) para começar algo novo (entrevistada 2).

Segundo Hu, Manikonda e Kambhampati (2014), usuários utilizam as redes como primeiro mecanismo de compartilhamento de fotos.

Então, eles (amigos) postavam algumas fotos no facebook e instagram, e ai comecei a ver o esporte (entrevistada 9).

Com o acesso às redes sociais, as pessoas passaram a buscar informações e interagir com terceiros em diferentes estágios do processo de consumo, sofrendo estímulos de diversas frentes na tomada de decisão, aquisição e uso de bens e serviços (FILO; LOCK; KARG, 2015). 


\subsubsection{2}

\section{Crescimento Desenfreado}

\begin{tabular}{|c|l|c|}
\hline CATEGORIAS INICIAIS & \multicolumn{1}{|c|}{ CONCEITO NORTEADOR } & CATEGORIA INTERMEDIÁRIA \\
\hline 3. O boom do crossfit & $\begin{array}{l}\text { Surgimento do crossfit e } \\
\text { muitas pessoas praticando e } \\
\text { divulgando ao mesmo tempo. }\end{array}$ & $\begin{array}{r}\text { II. Crescimento } \\
\text { desenfreado }\end{array}$ \\
\cline { 1 - 2 } 4. O esporte da moda & $\begin{array}{l}\text { Esporte "do momento", em } \\
\text { alta. }\end{array}$ & \\
\hline
\end{tabular}

Tabela 5: formação da categoria intermediária "Crescimento desenfreado"

Esta categoria de análise faz referência aos primeiros indícios do crossfit como esporte regulamentado e a quantidade de pessoas que aderiram ao esporte e começaram a divulgá-lo. Este crescimento desenfreado pode ser explicado pelo marketing inicial do crossfit feito pelos próprios praticantes, a curiosidade incitada naqueles que não o praticavam e o fato dele ter se tornado o esporte "do momento". A entrevistada 7 ilustra bem essa questão da "moda":

As pessoas começam a entrar porque veem outras fazendo, amigos, conhecidos e divulgação mesmo (entrevistada 7).

Blumer (1964) e Lang e Lang (1961) explicam esse crescimento desenfreado com base no modismo, afirmando que o movimento é algo que surge de repente e tem uma rápida disseminação, o que exemplifica bem o motivo do crossfit ter se tornado tão conhecido em um período de tempo tão curto. Em 2014, o crossfit chegou a 10 mil afiliados no mundo todo (BEERS, 2014).

Ainda, a entrevistada 10 comenta sobre o fato do crossfit ser uma novidade dentro do meio esportivo:

\footnotetext{
Esporte novo né? Se comparado com o que existia antes...tem poucos anos no Brasil. Faz ganhar força, resistência...queima calorias e é divertido. Foi a primeira atividade física que eu gostei. (...) Nunca tinha conseguido achar uma atividade física que eu gostasse. E o crossfit mudou isso pela primeira vez na minha vida. (...) Detesto academia (entrevistada 10).
}

Desde os anos 70, numerosos modismos e atividades têm surgido e desaparecido, o que tem encorajado as pessoas a manterem a saúde e forma física em dia (POWERS; GREENWELL, 2016). 


\title{
4.2.2.3
}

\section{Incentivo de Amigos}

\begin{tabular}{|l|l|l|}
\hline \multicolumn{1}{|c|}{ CATEGORIAS INICIAIS } & \multicolumn{1}{|c|}{ CONCEITO NORTEADOR } & CATEGORIA INTERMEDIÁRIA \\
\hline $\begin{array}{l}\text { 5. Amigos e comentários } \\
\text { positivos }\end{array}$ & $\begin{array}{l}\text { Os praticantes fazem } \\
\text { comentários positivos entre si } \\
\text { e com os não-praticantes } \\
\text { sobre os treinos e exercícios. }\end{array}$ & \multirow{2}{*}{ III. Incentivo de amigos } \\
6. Quantidade de amigos & $\begin{array}{l}\text { Evidencia o fato de muitos } \\
\text { conhecidos praticarem o } \\
\text { esporte e incitarem a vontade } \\
\text { no não-praticante de fazer } \\
\text { parte daquele grupo. }\end{array}$ & \\
\hline
\end{tabular}

Tabela 6: formação da categoria intermediária "Incentivo de amigos"

Observar amigos entusiasmados comentando sobre um assunto e, ainda, ver estes amigos realizando uma mesma atividade em comum, muitas vezes é o suficiente para que as pessoas se sintam motivadas a participar daquela ação. A terceira categoria intermediária, "incentivo de amigos", se refere exatamente a esta vontade de iniciar alguma coisa (neste caso, o crossfit) devido a influência direta ou indireta de amigos. Os trechos das entrevistas abaixo ilustram o quanto amigos podem incentivar e coagir a prática do esporte:

\begin{abstract}
Minha amiga ficou uns três meses me incentivando também. Enrolei, enrolei e resolvi ir. (...) Fui vendo fotos, amigos comentando e fazendo, e decidi entrar (para o crossfit) (entrevistada 4).

Meu irmão passou a me incentivar a fazer. Uma amiga também. Inclusive essa amiga era uma das que postavam fotos. Aí perguntei o que era aquilo que ela fazia e ela marcou uma aula experimental. (...) (minha amiga) Ela sempre falava que o crossfit reunia as coisas que eu gostava (entrevistada 8).
\end{abstract}

De acordo com Courneya et al. (2000) e Booth et al. (2000), o incentivo de amigos e os feedbacks positivos são fatores diretos importantes que fazem com que as pessoas pratiquem uma atividade física. Quando um grupo de amigos pratica determinada atividade física, por exemplo, isso faz com que a pessoa acabe se sentindo, de certa forma, coagida a praticar também, para que ela se sinta parte integrante daquele meio (DARLOW; XU, 2011; BAHR et al., 2009). 


\subsubsection{4}

\section{Identidade}

\begin{tabular}{|c|c|c|}
\hline CATEGORIAS INICIAIS & CONCEITO NORTEADOR & CATEGORIA INTERMEDIÁRIA \\
\hline $\begin{array}{l}\text { 7. Sensação de } \\
\text { pertencimento }\end{array}$ & $\begin{array}{l}\text { Evidencia o fato da vida passar } \\
\text { a "girar em torno" do crossfit, } \\
\text { em que até os amigos passam } \\
\text { a ser do meio e se ajudam. }\end{array}$ & \multirow{6}{*}{ IV. Identidade } \\
\hline $\begin{array}{l}\text { 8. Identificação de } \\
\text { trejeitos, gírias e roupas }\end{array}$ & $\begin{array}{l}\text { Após conhecer e se integrar } \\
\text { com pessoas do meio, o grupo } \\
\text { de amigos principal do } \\
\text { praticante passa a ser o do } \\
\text { crossfit e todos adquirem uma } \\
\text { linguagem em comum. }\end{array}$ & \\
\hline $\begin{array}{l}\text { 9. Comparações com } \\
\text { midiáticos }\end{array}$ & $\begin{array}{l}\text { O praticante compara seus } \\
\text { próprios exercícios e treinos } \\
\text { com atletas profissionais do } \\
\text { esporte. }\end{array}$ & \\
\hline $\begin{array}{l}\text { 10. Ilusão física e } \\
\text { autoestima }\end{array}$ & $\begin{array}{l}\text { Indica o aumento da auto } \\
\text { estima do praticante de } \\
\text { crossfit devido a ilusão de } \\
\text { embelezamento do proprio } \\
\text { corpo. }\end{array}$ & \\
\hline $\begin{array}{l}\text { 11. Mudança corporal e } \\
\text { autoestima }\end{array}$ & $\begin{array}{l}\text { Denota o aumento da } \\
\text { autoestima do praticante de } \\
\text { crossfit, devido mudanças } \\
\text { corporais visíveis. }\end{array}$ & \\
\hline $\begin{array}{l}\text { 12. Esporte, } \\
\text { comprometimento e } \\
\text { fitness }\end{array}$ & $\begin{array}{l}\text { Evidencia o comprometimento } \\
\text { total do praticante, dentro e } \\
\text { fora dos treinos. }\end{array}$ & \\
\hline
\end{tabular}

Tabela 7: formação da categoria intermediária "Identidade"

A quarta categoria intermediária "identidade" engloba todos os aspectos que dizem respeito à criação, modificação ou adaptação da identidade própria de um indivíduo através das adaptações do self. As categorias iniciais enumeradas de 7 a 12 são chaves para esta análise. Elas representam a categoria "identidade", pois todas elas se referem a alterações de comportamento físico e psicológico, culminando em internalizações e individualizações de atitudes capazes de modificar e/ou aprimorar a identidade do indivíduo. Cada uma das categorias iniciais foi explicada e embasada anteriormente, de modo que agora o foco será na construção da identidade. Alterações de perspectivas e mudanças de vida no mundo pessoal do praticante de crossfit são caracterizadas por Belger (2012), Murphy (2012) e Herz (2014) como a incorporação da atividade à identidade dos indivíduos. A 
entrevistada 10 deixa clara esta relação quando afirma a mudança que o crossfit trouxe para seu dia a dia:

Eu vejo no crossfit mais do que uma atividade física, mais do que um esporte. É como se fosse um estilo de vida, então eu comecei a me interessar mais por fazer dieta e por ter hábitos mais saudáveis (entrevistada 10).

Quando o indivíduo realiza dietas e atividades físicas com o intuito de modificar não só seus hábitos, mas também seu corpo, ele está unindo o self ao próprio corpo como uma forma de integração do todo (GIDDENS, 1991), assegurando não só a difusão, mas a própria construção de sua identidade (CORDEIRO, 2011).

Ainda, a construção da identidade através da realização de atividades físicas também está muito relacionada com a participação e treinamento em grupos, que passam uma sensação de pertencimento (BELK 1988; CORDEIRO, 2011) citada, por exemplo, pela entrevistada 6:

Formamos um grupo de amigos lá, estamos sempre juntos e nos identificamos muito. As vezes vou treinar só para vê-los, sabe? (entrevistada 6).

Scott (2010) cita a nova Instituição Reinventiva, que elucida o processo de "aprimoramento pessoal voluntário", em que o indivíduo busca participar de uma instituição para a autoajuda e introspeção como forma de reabilitação e aprimoramento de sua própria identidade. Nota-se esta mudança através do exemplo abaixo:

Agora tenho toda uma consciência de comer melhor, dormir bem, fazer alongamentos. Acho que tudo isso, junto, traz uma sensação de bemestar que fica lá em cima...disposição, energia, sabe? (entrevistada 4).

A Instituição Reinventiva (SCOTT, 2010) busca criar um self totalmente novo de forma positiva para a mudança no estilo de vida (SCOTT 2011). 


\subsubsection{5}

\section{Socialização e Comunicabilidade}

\begin{tabular}{|c|c|c|}
\hline CATEGORIAS INICIAIS & CONCEITO NORTEADOR & CATEGORIA INTERMEDIÁRIA \\
\hline $\begin{array}{l}\text { 13. Comunicação e } \\
\text { integração }\end{array}$ & $\begin{array}{l}\text { Indica o fato do crossfit } \\
\text { transformar os praticantes } \\
\text { em pessoas mais } \\
\text { comunicativas e, } \\
\text { consequentemente, } \\
\text { motivadas. }\end{array}$ & \multirow[t]{2}{*}{$\begin{array}{l}\text { V. Socialização e } \\
\text { comunicabilidade }\end{array}$} \\
\hline 14. Amizades do esporte & $\begin{array}{l}\text { Evidencia a criação de novos } \\
\text { laços de amizade dentro do } \\
\text { crossfit. }\end{array}$ & \\
\hline
\end{tabular}

Tabela 8: formação da categoria intermediária "Socialização e comunicabilidade"

A presente categoria intermediária evidencia não só a transformação de indivíduos praticantes em pessoas mais sociáveis e motivadas, mas também a criação de novas amizades, que passam a ser as principais do praticante. Abaixo, o trecho da entrevista ilustra o fato:

Conheço todo mundo lá. Fico lá conversando horas com os professores e com os amigos e amigas que fiz lá. (...) O crossfit me trouxe e me traz amigos, alguns mais próximos do que outros. Tenho amigos que fazem comigo atualmente e às vezes vamos juntos (entrevistada 2).

Segundo McKenzie (2013), com o passar dos anos as academias se tornaram locais de troca social, interação e compartilhamento de interesses em comum, o que explica a criação de novos laços de amizade e sensação de comunidade (GLASSMAN, 2011). Ainda, Dishman, Sallis e Orenstein (1985) afirmam que a aquisição de novas habilidades comportamentais, e aqui podemos citar a maior comunicabilidade, faz com que os praticantes da atividade permaneçam nela.

\subsubsection{6}

\section{Exibicionismo}

\begin{tabular}{|l|l|l|}
\hline \multicolumn{1}{|c|}{ CATEGORIAS INICIAIS } & \multicolumn{1}{|c|}{ CONCEITO NORTEADOR } & CATEGORIA INTERMEDIÁRIA \\
\hline $\begin{array}{l}\text { 15. Autoestima e } \\
\text { exibicionismo }\end{array}$ & $\begin{array}{l}\text { Evidencia o aumento da } \\
\text { autoestima através do } \\
\text { exibicionismo online }\end{array}$ & \multirow{2}{*}{ VI. Exibicionismo } \\
\hline $\begin{array}{l}\text { 16. Fotos, inovação e } \\
\text { superação de metas }\end{array}$ & $\begin{array}{l}\text { As fotos divulgadas pelos } \\
\text { praticantes estimulam o } \\
\text { conhecimento e a } \\
\text { curiosidade, pois passam a } \\
\text { sensação da capacidade de } \\
\text { superação de metas. }\end{array}$ & \\
\hline
\end{tabular}

Tabela 9: formação da categoria intermediária "Exibicionismo" 
A sexta categoria intermediária, "exibicionismo", diz respeito ao aumento do exibicionismo a partir da prática do crossfit. Este exibicionismo ocorre, principalmente, através das postagens de fotos online, que recebem comentários normalmente positivos de terceiros, aumentando o ego e, consequentemente, a autoestima do praticante. Esta divulgação também ajuda na promoção do esporte e transmite a ideia de superação.

A entrevistada 1 fala um pouco desta exibição online do rendimento próprio, deixando oculta a informação de que posta fotos apenas de momentos "de glória" e de superação em busca, provavelmente, de comentários positivos nas fotos:

\footnotetext{
Os stories são mais coisas do dia a dia. As fotos eu deixo pra campeonato ou momentos mais especiais. Por exemplo, eu fiz stories sobre minhas dificuldades na última prova do open, mas se for para postar no feed, vai ser aquela foto fazendo o open, sabe? (entrevistada $1)$.
}

Goffman (1956) faz uma observação interessante sobre esta exibição "seletiva", que vai de encontro com a afirmação da entrevistada. $\mathrm{O}$ autor diz que os indivíduos buscam adotar identidades diferenciadas de acordo com as situações em que vivem, fazendo com que procurem passar a impressão de que estão de acordo com os padrões pelos quais serão julgados. A entrevistada 4 também fala um pouco desta "seleção" de fotos e se abre mais sobre a questão dos comentários positivos:

\footnotetext{
Acho que você vai postar a foto que você acha que está bem, ou para passar alguma mensagem, ou para mostrar que conquistou alguma coisa. E acho que tem um retorno, sabe? As pessoas veem, curtem e acabam te incentivando, sem querer, a continuar a praticar. Fora a parte estética que você sente logo o resultado, né? E aí visualmente você se sente bem (entrevistada 4).
}

Atualmente, a auto apresentação e auto divulgação são elementos chave nas mídias sociais (KAPLAN; HAENLEIN, 2010), e com o advento delas aliado à pratica de um esporte que provoca alterações físicas positivas, os indivíduos estão cada vez mais se exibindo, mostrando seus corpos e divulgando seus momentos fitness.

A entrevistada abaixo cita bem o exemplo do aumento do exibicionismo, quando diz que tinha vergonha de si, e agora não tem mais.

\footnotetext{
Ah, é porque já faz parte da minha rotina. Da mesma forma que posto com amigos, festas, viagens, posto no crossfit. Confesso que no início eu tinha vergonha, mas hoje faço até pose. (...) Tem vaidade, sabe? Acho que é consequência (da melhora do corpo), claro, de se exibir um pouco (entrevistada 8).
} 
Fredrickson e Roberts (1997) citam a Teoria da Objetificação que assume que através das ferramentas de compartilhamento de fotos ocorre a objetificação do self, enquanto pode-se complementar com Festinger (1954) e a Teoria da Comparação Social, em que a visibilidade destas fotos e o feedback (comentários e curtidas) encorajam a comparação social. Agora, os consumidores se sentem livres para expressar suas identidades através dessas novas associações, o que aumenta o caráter exibicionista (SCHAU; GILLY, 2003).

\subsubsection{7}

\section{Autoconfiança}

\begin{tabular}{|l|l|l|}
\hline \multicolumn{1}{|c|}{ CATEGORIAS INICIAIS } & \multicolumn{1}{|c|}{ CONCEITO NORTEADOR } & CATEGORIA INTERMEDIÁRIA \\
\hline $\begin{array}{l}\text { 17. Autoconfiança e } \\
\text { tarefas pessoais }\end{array}$ & $\begin{array}{l}\text { Ganho de autoconfiança para } \\
\text { realização de tarefas pessoais } \\
\text { e diárias. }\end{array}$ & \multirow{2}{*}{ VII. Autoconfiança } \\
\cline { 1 - 2 } $\begin{array}{l}\text { 18. Auto desafio e } \\
\text { superação }\end{array}$ & $\begin{array}{l}\text { Ganho de autoconfiança } \\
\text { através da superação de } \\
\text { desafios pessoais nos treinos. }\end{array}$ & \\
\hline
\end{tabular}

Tabela 10: formação da categoria intermediária "Autoconfiança"

Cordeiro (2011) afirma que as transformações físicas e mentais que o esporte promove no corpo alteram a visão própria de cada indivíduo, modificando as narrativas essenciais para a construção da auto identidade, aumentando a autoconfiança, tanto para a realização da própria atividade física quanto para atividades do dia a dia. Para exemplificar, o trecho da entrevista abaixo fala sobre esta alteração no próprio ego e aumento da autoconfiança:

\footnotetext{
(O esporte) também mudou algumas formas de pensar que eu levo para a vida. Não existe mais "eu acho que consigo" ou "eu não consigo fazer tal coisa". Eu simplesmente vou lá e faço. Tento pelo menos. Se não consegui, é um "não consigo ainda", porque mais um pouco de dedicação e eu faço, entende? (...) Me sinto mais autoconfiante (...). Hoje penso que se eu me dedicar, eu posso sim conseguir atingir meu
}

A entrevistada afirma que o esporte mudou sua forma de pensar e diz que se sente mais autoconfiante, indo de encontro com a afirmação de Cordeiro (2011) sobre as transformações do indivíduo em relação a ele mesmo. 


\subsection{3}

\section{Categorias Finais}

As categorias iniciais e intermediárias apresentadas nas seções anteriores serviram de respaldo para a elaboração das categorias finais. Esta fase final é constituída por três categorias: modismo; identidade social; e mídias sociais, exibicionismo e autoestima.

\subsubsection{1}

\section{Modismo}

\begin{tabular}{|l|l|l|}
\hline CATEGORIAS INTERMEDIÁRIAS & \multicolumn{1}{|c|}{ CONCEITO NORTEADOR } & CATEGORIA FINAL \\
\hline $\begin{array}{l}\text { I. Disseminação e } \\
\text { divulgação online }\end{array}$ & $\begin{array}{l}\text { Evidencia a quantidade de } \\
\text { pessoas praticando o crossfit e } \\
\text { disseminando o esporte } \\
\text { através das mídias, gerando } \\
\text { conhecimento. }\end{array}$ & \multirow{2}{*}{ I. Modismo } \\
\hline $\begin{array}{l}\text { Il. Crescimento } \\
\text { desenfreado }\end{array}$ & $\begin{array}{l}\text { A disseminação do crossfit } \\
\text { promove o conhecimento e, } \\
\text { consequentemente, o } \\
\text { crescimento desenfreado da } \\
\text { modalidade. }\end{array}$ & \\
\hline
\end{tabular}

Tabela 11: formação da categoria final "Modismo"

A primeira categoria final principal é o "modismo". Identificado em 100\% das entrevistas, o crossfit está dentro do que pode-se chamar de "esporte da moda". De diversas formas e através de diferentes explicações, as entrevistadas demonstravam que o súbito interesse em praticar o crossfit teve início porque "todo mundo estava fazendo". O modismo, diferente de uma tendência, segundo Blumer (1964) é totalmente inesperado. Ele inicia sem nenhum indício anterior daquilo. De repente, começa e tem rápida disseminação (LANG; LANG, 1961). Não raro, com a disseminação desenfreada e crescimento exponencial, ele tem rápida aceitação (BLUMER, 1968).

Quando comecei, tinha bastante gente começando a fazer. Era bem divulgado. Mas atualmente tem menos né? Acho que esses exercícios novos têm um ciclo de moda. Pilates foi assim. Crossfit. Vários esportes. Até musculação mesmo. Cada época, um exercício fica muito em alta e todo mundo procura. Abrem milhares de academias. (...) As pessoas começam a entrar porque veem outras fazendo, amigos, conhecidos e divulgação mesmo (entrevistada 7).

O trecho da entrevista acima mostra que, quando a entrevistada iniciou a prática do crossfit, muitas pessoas já o conheciam e praticavam. Nota-se que ela tenta driblar 
a informação sobre ter começado a atividade por causa da "moda", transferindo a fala para termos gerais e para terceiros como "acho que esses exercícios têm um ciclo de moda" ou "as pessoas começam a entrar porque veem outras fazendo". Tanto a partir da fala dela quanto de outras entrevistadas, percebe-se uma forma de comportamento coletivo, caracterizado pela homogeneidade, com muitas pessoas praticando o mesmo esporte e agindo da mesma forma (AGUIRRE; QUARANTELLI; MENDOZA, 1988).

Para que essa influência de comportamento ocorresse, era necessária a disseminação da informação das atitudes e comportamentos de terceiros (MARSDEN; FRIEDKIN, 1993), o que ocorreu, principalmente, através das redes sociais, como ilustrado abaixo:

As pessoas postavam no instagram (...). Tenho conhecidos que começaram a fazer (crossfit) e a postar. Eram mais stories mesmo. Videos de wods, do levantamento de peso, do esforço físico (entrevistada 3).

A disseminação da informação e comportamento coletivo acarretou em um contágio comportamental, explicado por Lippitt, Polansky e Rosen (1952) pela aquisição espontânea de um comportamento iniciado, propositalmente ou não, por um indivíduo e imitado por terceiros.

\subsubsection{2}

\section{Identidade Social}

\begin{tabular}{|l|l|c|}
\hline \multicolumn{1}{|c|}{ CATEGORIAS INICIAIS } & \multicolumn{1}{|c|}{ CONCEITO NORTEADOR } & CATEGORIA FINAL \\
\hline 3. Incentivo de amigos & $\begin{array}{l}\text { Indica o início da prática do } \\
\text { crossfit devido incentivo de } \\
\text { amigos e conhecidos. }\end{array}$ & \multicolumn{1}{|c|}{} \\
\hline 4. Identidade & $\begin{array}{l}\text { Evidencia a criação de uma } \\
\text { nova identidade e/ou } \\
\text { transformação da identidade } \\
\text { própria existente através das } \\
\text { alterações físicas, psicológicas } \\
\text { e comportamentais } \\
\text { acarretadas pela prática do } \\
\text { crossfit. }\end{array}$ & \multirow{2}{*}{ II. Identidade Social } \\
\hline 5. Socialização e & $\begin{array}{l}\text { Evidencia a criação de novas } \\
\text { amizades dentro do âmbito do } \\
\text { crossfit, levando a alterações } \\
\text { comportamentais em níveis } \\
\text { motivacionais e de } \\
\text { comunicação e socialização. }\end{array}$ & \\
\hline
\end{tabular}

Tabela 12: formação da categoria final "Identidade social" 
A segunda categoria final encontrada foi a "identidade social". A partir da transformação da identidade pessoal, aliada ao incentivo dos amigos e a maior socialização, foi possível encontrar traços claros de uma identidade social.

Estudos mostram que os indivíduos navegam nas mídias sociais em busca de repassar a terceiros suas crenças e atitudes, a fim de criar, formar e explorar identidades (COYNE; PADILLA-WALKER; HOWARD, 2013). No crossfit, as pessoas percebem estes comportamentos, crenças e atitudes através das mídias sociais e, de alguma forma, se identificam, iniciando a atividade. Segundo Tajfel (1982) e Tajfel e Turner (1979), a Teoria da Identidade Social consiste no fato de que as pessoas buscam fazer parte de grupos que reflitam seus próprios conceitos de self. Todos possuem uma identidade pessoal que aliada a grupos de indivíduos que tenham conceitos similares, torna-se uma identidade social. O autoconceito de cada indivíduo depende tanto das características da identidade pessoal habilidades, interesses, etc - quanto das características compartilhadas de grupo pertencer a determinado grupo traz algum valor (ASHFORTH; MAEL, 1989). O trecho da entrevista abaixo ilustra este pertencimento a um grupo, em que a entrevistada denomina como "seita".

\footnotetext{
Quase todos os meus melhores amigos são do crossfit. Meu namorado também é do crossfit. A vida gira um pouco em torno do crossfit. Por isso que as pessoas falam que isso é uma seita (entrevistada 1).
}

Belk (1988) afirma que as posses, lugares, grupos e pessoas também se tornam parte do self, o que vai de encontro com outros autores que afirmam que a identidade pode ser construída a partir de atividades esportivas com as modificações comportamentais e sensação de pertencimento (Belk 1988; CORDEIRO, 2011), mudanças corporais (CORDEIRO, 2011; GIDDENS, 1991; FREDRICKSON; ROBERTS, 1997), mídias online (SMITH; SANDERSON, 2015; KIM; PAPACHARISSI, 2003) e incorporação voluntária a uma instituição (SCOTT, 2011). A entrevistada abaixo ilustra esta questão:

Como a personalidade acaba sendo um pouco a maneira de se vestir, de usar roupas de crossfit, acaba mudando um pouco nesse sentido. De ter novos gostos, novos ambientes, e acabar convivendo mais com pessoas que têm a mesma vibe (entrevistada 10) 
Aqui, claramente percebe-se a transformação da identidade pessoal, principalmente quando ela cita a mudança de personalidade, assim como a incorporação de uma identidade social, em que gostos e comportamentos se equiparam.

Ainda, ambas as entrevistadas falam em mudança de comportamentos assim como citam o pertencimento a um novo grupo de amigos. Amigos estes que partilham das mesmas características, o que vai e encontro com Cova e Cova (2002) e a definição de tribos. Também, Thompson e Holt (1996) complementam afirmando que essas tribos possuem atributos que dão suporte à união, podendo ser um lugar ou ritual de integração e reconhecimento. Nota-se, claramente, o reconhecimento entre si dos membros do crossfit através da utilização do mesmo estilo de roupas, linguagem e lugares que frequentam.

\subsubsection{3}

Mídias Sociais, Exibicionismo e Autoestima

\begin{tabular}{|c|c|c|}
\hline CATEGORIAS INICIAIS & CONCEITO NORTEADOR & CATEGORIA FINAL \\
\hline 5. Exibicionismo & $\begin{array}{l}\text { Indica o aumento do } \\
\text { exibicionismo nas mídias } \\
\text { online devido alterações físicas } \\
\text { e comportamentais. }\end{array}$ & \multirow{2}{*}{$\begin{array}{c}\text { III. Mídias sociais, } \\
\text { exibicionismo e } \\
\text { autoestima }\end{array}$} \\
\hline 6. Autoconfiança & $\begin{array}{l}\text { Evidencia o surgimento ou } \\
\text { aumento da autoconfiança } \\
\text { devido a prática do crossfit e } \\
\text { transferência de valores para a } \\
\text { vida pessoal. }\end{array}$ & \\
\hline
\end{tabular}

Tabela 13: formação da categoria final "Mídias sociais, exibicionismo e autoestima"

A terceira e última categoria final, "mídias sociais, exibicionismo e autoestima", foi encontrada a partir da avaliação de como o crossfit pode alterar a vida pessoal do praticante. Nesta seção, percebe-se o forte aumento do exibicionismo nas mídias sociais devido mudança corporal, porém com alterações positivas na autoconfiança e, consequentemente, autoestima do praticante.

Atualmente, segundo Marshall (2010), as mídias online permitem construir e publicar diferentes representações de si mesmo, além de identidade (BULLINGHAM; VASCONCELOS, 2013) através do compartilhamento de fotos, principalmente quando relacionadas à aparência física (FOX; VENDEMIA, 2016). O trecho retirado da primeira entrevista ilustra esse exibicionismo: 
crossfit. Mas as minhas fotos favoritas são as que demonstram alguma conquista...quando a foto pega um momento de recorde pessoal...ou em grupo, principalmente em campeonato em trio ou equipe (entrevistada $1)$.

Fica clara essa relação do compartilhamento de fotos com o exibicionismo, principalmente quando a entrevistada cita a postagem de foto de um "momento de recorde pessoal". Abaixo mais um exemplo, quando a entrevistada 10 afirma postar quando consegue executar um bom movimento:

Quando consigo executar um movimento novo, fico feliz e quero postar. Acho que é tipo um marco por ter conseguido atingir um objetivo (entrevistada 10).

Em correlação com as afirmações acima, segundo Haferkamp et al. (2012), as mulheres costumam demonstrar maior foco na aparência física em suas redes sociais, afinal, com a cultura atual da boa forma, agora ser fitness se tornou sinônimo de beleza (BOLIN; GRANSKOG, 2003; DWORKIN; WACHS, 2009), e portanto, deve ser divulgado.

Quando vejo no crossfit ou pela rua alguém gordinho, eu penso "ainda bem que não estou assim", ou "que bom que entrei para o cross". Atualmente me sinto melhor. Meu corpo e autoestima. (...) Percebo mudança no meu corpo. Tiro muita foto de mim mesma, pra perceber essas diferenças (entrevistada 2).

Eu sou uma pessoa insegura e me cobro muito. Acho que eu acredito mais no meu potencial, na minha força. Não física, sabe? Mas mental mesmo. De saber que eu posso (entrevistada 8).

Ainda, Shin et al. (2017) e Gonzales e Hancock (2011) comentam que este compartilhamento de autorretratos nas mídias sociais causa o aumento da autoestima. Com essa mudança corporal e comportamental, a autoconfiança e autoestima também aumentam, o que pode ser exemplificado pelas linhas das entrevistadas acima. Ambas citam aumento de autoestima e autoconfiança, que são provenientes destas alterações identitárias causadas pela prática do crossfit. 


\section{5 \\ Conclusões}

\section{1}

\section{Discussão dos Resultados Obtidos}

Este estudo tinha como primeiro foco identificar o modismo como principal traço motivador de aderência ao crossfit. A partir deste ponto, o objetivo era descobrir se este modismo se transformaria ou não em parte integrante da identidade do atleta amador e avaliar as possíveis razões que influenciam a incorporação deste modismo a identidade.

Através das categorias encontradas a partir das referências citadas e correlacionadas com as entrevistas, foi possível chegar primeiramente à conclusão de que o modismo é o maior fator de influência para começar a prática do crossfit. As entrevistadas afirmam que a quantidade de pessoas praticando a atividade foi, em grande parte, o ponto principal para que elas iniciassem a atividade. Dentre os jargões mais comuns para esta evidência estavam "vi todo mundo fazendo", "geral postando sobre o crossfit" ou "estava na moda".

Outro ponto a ser avaliado era a incorporação deste modismo à identidade, o que pôde ser identificado claramente nas entrevistas. A análise mostra que boa parte das entrevistadas passaram a seguir conceitos fiéis do esporte, desde formas diferenciadas de se vestir - com roupas específicas de crossfit - até mudanças comportamentais como equilíbrio alimentar, alterações na autoconfiança, autoestima e troca de grupos sociais. Ainda, todas estas características, como citado no referencial e na análise, estão relacionadas à construção e formação de identidade, o que prova a incorporação do modismo à identidade do praticante de crossfit.

Ainda, e como parte do objetivo final, dentre as razões para a incorporação deste modismo estão a visualização de fotos que, conforme trechos das entrevistas, passam a ideia de um esporte dinâmico, inovador e, principalmente, desafiador, que faz com que os indivíduos se sintam coagidos a praticar, se auto desafiar e trabalhar a capacidade de superação. Ainda, mais uma razão importante para a incorporação do modismo é a identificação por parte do não praticante, com a identidade do 
usuário praticante de crossfit que posta as fotos das mídias sociais. Essa identificação insere-se no âmbito da Teoria da Identidade Social (TAJFEL 1982; TAJFEL; TURNER, 1979) comentada na análise. Como parte da teoria, após início da atividade, o praticante se sente parte do grupo, inserido em uma comunidade, o que aumenta sua participação e tempo de permanência no esporte.

A classificação de identidade tanto fora das mídias (BELK, 1988) como a extensão do self com o advento nas mídias sociais (BELK, 2013; BELK, 2014a; BELK, 2014b) e, sobretudo, as teorias utilizadas neste trabalho como a Teoria da Identidade Social (TAJFEL 1982; TAJFEL; TURNER, 1979), a Teoria da Objetificação (FREDRICKSON; ROBERTS, 1997) e a Teoria da Comparação Social (FESTINGER, 1954), se mostraram relevantes e com capacidade de explicar a incorporação do modismo esportivo à identidade, por parte das mulheres.

Indo além do objetivo deste trabalho, outra conclusão pode ser inferida. Apesar do crossfit ser um modismo no Brasil, notam-se claras características de tribos (COVA; COVA, 2002) nos praticantes deste esporte. Através das entrevistas, identifica-se a importância da formação de grupos que influenciam no comportamento dos integrantes do crossfit. Os praticantes do esporte criam um forte laço social (MAFFESOLI, 1996), através de atitudes, emoções, paixões e pensamentos semelhantes, que são compartilhados uns com os outros (KOZINETS, 1999). Os crossfitters mantém um compromisso quase que ritualístico de treinar juntos, sempre nos mesmos horários, construindo o que Cova e Cova (2002) chamam de costumes cíclicos que, por sua vez, mantém a identidade da tribo.

O crossfit ainda é um esporte relativamente novo no Brasil que, através das entrevistas, percebe-se seu início com características claras de modismo. O modismo é caracterizado pela rapidez na disseminação de uma atitude ou pensamento inesperado (LANG; LANG, 1961), pela rápida aceitação, mas também pelo ciclo curto de sua existência (BLUMER, 1968). Alguns elementos nas entrevistas e na literatura fortalecem que o crossfit pode estar se tornando um clássico, e não apenas uma moda com início, meio e fim. Algumas entrevistadas afirmam realmente gostar do esporte e não se imaginam sem ele daqui alguns anos. Se o crescimento continuar e não ocorrer uma curva de redução de praticantes, o crossfit pode acabar deixando de ser apenas um modismo. Assim como o próprio Herz (2014) cita, o crossfit teve início nos Estados Unidos no ano de 2000 e 
atualmente é um dos esportes mais conhecidos e com maior crescimento no mercado. Portanto, nota-se claramente a tendência em ser um clássico.

Estas conclusões podem ser estendidas para outros esportes. Outras atividades físicas que começaram apenas como modismo podem estar adquirindo características de clássicos e irão perdurar por anos, assim como algumas outras atividades podem já ter atingido seu pico e estão reduzindo até que não as veremos mais. Todas essas atividades seguem padrões semelhantes e também podem estar associadas à formação de "tribos" que compartilhem dos mesmos interesses e ideias.

\section{2}

\section{Aplicações Gerenciais}

Considerando que as redes sociais são, atualmente, o primeiro meio de contato dos indivíduos com novos esportes e marcas, as empresas precisam pensar em estratégias que incluam em seu planejamento a divulgação primária via estas mídias.

Sendo o modismo atingido a partir da proliferação em massa de um mesmo conteúdo, principalmente fotos, novas marcas esportivas no mercado podem aproveitar para expandir suas divulgações e investir em quantidade e qualidade de anúncios para Facebook e Instagram - mídias mais utilizadas.

Como as fotos possuem alto poder apelativo, anúncios em carrossel no Facebook e Instagram - em que aparece uma sequência de imagens e o próprio cliente passa as fotos uma a uma - são apostas importantes para criar um awareness significativo. Como observado, atualmente o stories do Instagram também é muito utilizado para compartilhamento de conteúdo. Empresas também têm a oportunidade de criar anúncios patrocinados, que aparecem nos stories do público-alvo da mesma.

Ainda, aproveitando a identificação do praticante do esporte com a atividade e o nicho, inclusive através do vestuário, nota-se a oportunidade de desenvolvimento de produtos específicos, que tragam em sua essência a identidade da atividade esportiva ao praticante, de forma que ele se sinta pertencente àquele nicho quando consome o produto. 


\section{3 \\ Sugestões para Novas Pesquisas}

As entrevistas foram realizadas apenas com mulheres. Estudos com foco nos homens poderiam trazer novos insights para a incorporação do modismo à identidade. Ainda, como a proximidade do pesquisador ao entrevistado foi necessária devido tempo disponível para pesquisa, praticantes de crossfit de outros estados não foram considerados. Há grande possibilidade de expandir a pesquisa para diferentes localidades, que possuam culturas distintas das presentes no Rio de Janeiro, a fim de avaliar outros motivos para a aderência ao esporte e se o modismo é uma característica marcante para o início da atividade.

Alguns autores se debruçam na Teoria da Objetificação do Corpo (FREDRICKSON; NOLL, 1998; FREDRICKSON; ROBERTS, 1996) e Teoria da Comparação Social (FESTINGER, 1954) para entender as consequências de ser mulher, em uma cultura que sexualmente objetifica o corpo feminino, através da comparação social. Mulheres que levam em conta a perspectiva do observador (ao invés da sua própria) (FREDRICKSON; ROBERTS, 1996) e a comparação social (FESTINGER. 1954) como a visões principais e primárias para atingir seu próprio físico ideal. Dentro deste contexto, e com base nos resultados da análise, podem ser realizados maiores estudos e entrevistas acerca do crossfit como atividade física realizada apenas para atingir o físico objetificado pela sociedade, em que o esporte se torna uma atividade-meio, e não atividade-fim.

Ainda, aqui falamos do modismo, porém com base em um esporte apenas, devido limitação de pesquisadores e tempo para realização das pesquisas. Porém, futuros estudos podem ser direcionados para outros esportes, com o objetivo de confirmar a expansão dos resultados obtidos aqui em outras modalidades. Em caso de resultados similares, avaliações gerenciais e mudanças de estratégias de marca poderiam ser conduzidas a fim de atingir diretamente este público adepto ao "modismo". 


\section{6 \\ Referências bibliográficas}

AAKER, D.; KUMAR, V.; DAY, G. Pesquisa de Marketing. 2. ed. São Paulo: Atlas, 2004.

AGUIRRE, B. E.; QUARANTELLI, E. L.; MENDOZA, J. L. The Collective Behavior of Fads: The Characteristics, Effects, and Career of Streaking. American Sociological Review, v. 53, n. 4, p. 569-584, 1988.

AHUVIA, A. C. Beyond the Extended Self: Loved Objects and Consumers' Identity Narratives. Journal of Consumer Research, v. 32, n. 1, p. 171-184, 2005.

ALLEN, R. How popular is Facebook vs Twitter vs Instagram vs Snapchat vs Pinterest? Disponível em: <https://www.smartinsights.com/social-mediamarketing/social-network-landscape-chartoftheday/>. Acesso em: 25 out. 2017.

ANDRIOPOULOS, C.; SLATER, S. Exploring the landscape of qualitative research in international marketing: Two decades of IMR. International Marketing Review, v. 30, n. 4, p. 384-412, 2013.

ARGAEZ, E. DE. Internet World Stats: Usage and Population Statistics. Disponível em: <http://www.internetworldstats.com/stats.htm>. Acesso em: 20 jun. 2017.

ARON, A. et al. Close relationships as including other in the self. Journal of Personality and Social Psychology, v. 60, n. 2, p. 241-253, 1991.

ARON, A.; ARON, E. N. Love as the Expansion of Self: Understanding Attraction and Satisfaction. Nova Iorque: Taylor \& Francis Inc, 1986.

ASHFORTH, B.; MAEL, F. Social Identity Theory and the Organization. Academy of Management Review, v. 14, n. 1, p. 20-39, 1989.

AUDREI, J. Mercado Fitness Pode Movimentar R\$27 Bilhões em 2020 no Brasil. Disponível em: <http://www.madara.com.br/mercado-fitness-podemovimentar-r-27-bilhoes-em-2020-no-brasil/> . Acesso em: 27 dez. 2017.

AUDREI, J. Crescimento do Marketing Digital no Brasil. Disponível em: <http://www.madara.com.br/crescimento-marketing-digital-no-brasil-dados-demercado-2017/>. Acesso em: 15 ago. 2017.

BACK, M. D. et al. Facebook Profiles Reflect Actual Personality, Not SelfIdealization. Psychological Science, v. 21, n. 3, p. 372-374, 2010. 
BAHR, D. B. et al. Exploiting Social Networks to Mitigate the Obesity Epidemic. Obesity, v. 17, n. 4, p. 723-728, 2009.

BAILEY, K. D. Typologies and Taxonomies: An Introduction to Classification Techniques. $1^{a}$ ed. Thousand Oaks: Sage Publications, 1994.

BANERJEE, A. V. A Simple Model of Herd Behavior. The Quarterly Journal of Economics, v. 107, n. 3, p. 797-817, 2010.

BAPTISTA, L. C. Framing and Cognition. In: Goffman's Legacy. Trevino ed. Nova Iorque: Rowman and Littlefield, 2003. p. 197-215.

BARDIN, L. Análise de Conteúdo. $1^{\text {a }}$ ed. São Paulo: Edições 70, 2011.

BAREKET-BOJMEL, L.; MORAN, S.; SHAHAR, G. Strategic Self-Presentation on Facebook: Personal Motives and Audience Response to Online Behavior. Computers in Human Behavior, v. 55, p. 788-795, 2016.

BARTHES, R. Sistema de Moda. $1^{\text {a }}$ ed. São Paulo: Martins Fontes, 2009.

BAUER, M. W.; AARTS, B. A Construção do Corpus: Um Princcípio para a Coleta de Dados 1ualitativos. In: Pesquisa Qualitativa com Texto, Imagem e Som: Um Manual Prático. $7^{\mathrm{a}}$ ed. Petrópolis: Vozes, 2008. p. 39-63.

BAUMAN, Z. Identity in the Globalising World. Social Anthropology, v. 9, n. 2, p. 121-129, 2001.

BAUMAN, Z. Thinking Sociologically. $1^{\text {a }}$ ed. Oxford: Blackwell, 1990.

BEERS, E. Virtuosity Goes Viral. The CrossFit Journal, p. 1-10, 2014.

BELGer, A. The Power of Community: CrossFit and the Force of Human Connection. Victory Belt Publishing, 2012.

BELK, R. Digital Consumption and The Extended Self. Journal of Marketing Management, v. 30, n. 11-12, p. 1101-1118, 2014a.

BELK, R. W. Identity and the Relevance of Market, Personal, and Community Objects. In: Marketing and Semiotics: New Directions in the Study of Signs for Sale. Berlin: Mouton de Gruyter, 1987. p. 151-164.

BELK, R. W. Possessions and the Extended Self. Journal of Consumer Research, v. 15 , n. 2, p. 139-168, 1988.

BELK, R. W. Extended Self and Extending Paradigmatic Perspective. Journal of Consumer Research, v. 16, n. 1, p. 129, 1989.

BELK, R. W. Possessions and the Sense of Past. Highways and Buyways, p. 114130, 1991.

BELK, R. W. Extended Self in a Digital World. Journal of Consumer Research, v. 40, n. 3, p. 477-500, 2013. 
BELK, R. W. Alternative Conceptualizations of the Extended Self. Advances in Consumer Research, v. 42, n. 1988, p. 251-254, 2014b.

BERG, B. L. Qualitative Research Methods for the Social Sciences. $8^{\mathrm{a}}$ ed. Long Beach: Pearson, 2011.

BIDDLE, S. J. H.; BAILEY, C. I. A. Motives for Participation and Attitudes Toward Physical Activity of Adult Participants in Fitness Programs. Perceptual and Motor Skills, v. 61, n. 3, p. 831-834, 1985.

BLUMER, H. Collective Behavior. In: An Outline of the Principles of Sociology. Nova Iorque: Barnes and Noble, 1964. p. 165-200.

BLUMER, H. Fashion. In: International Encyclopedia of the Social Sciences. Nova Iorque: Macmillan, 1968. p. 341-345.

BOLIN, A.; GRANSKOG, J. Athletic Intrudors: Ethnographic Research on Women, Culture, and Exercise. Albany: State University of New York Press, 2003.

BOLTER, J. Virtual Reality and the Redefinition of Self. In: Communication and Cyberspace: Social Interaction in an Eletronic Environment. $1^{\mathrm{a}}$ ed. Cresskill: Hampton Press, 1996. p. 404.

BOOTH, M. L. et al. Social-cognitive and Perceived Environment Influences Associated with Physical Activity in Older Australians. Preventive Medicine, v. 31, n. 1, p. 15-22, 2000.

BORN, G. Music and the Materialization of Identities. Journal of Material Culture, v. 16, n. 4, p. 376-388, 2011.

BRITT, S. H. Consumer Behavior and the Behavioral Sciences: Theories and Applications. Nova Iorque: John Wiley \& Sons, 1966.

BRODIE, R. J. et al. Customer Engagement: Conceptual Domain, Fundamental Propositions, and Implications for Research. Journal of Service Research, v. 14, n. 3, p. 252-271, 2011.

BRODIE, R. J. et al. Consumer Engagement in a Virtual Brand Community: An Exploratory Enalysis. Journal of Business Research, v. 66, n. 1, p. 105-114, 2013.

BULLINGHAM, L.; VASCONCELOS, A. C. "The Presentation of Self in the Online World": Goffman and the Study of Online Identities. Journal of Information Science, v. 39, n. 1, p. 101-112, 2013.

BURNARD, P. A Method of Analysing Interview Transcripts in Qualitative Research. Nurse Education Today, v. 11, p. 461-466, 1991.

BURT, R. S. Social Contagion and Innovation: Cohesion versus Structural Equivalence. American Journal of Sociology, v. 92, n. 6, p. 1287-1335, 1987. 
BUTTS, F. B. NCAA Athletes and Facebook. The Sport Journal, v. 11, n. 1, p. 23-30, 2008.

CARTWRIGHT, D. Influence, Leadership, Control. In: Handbook of Organizations. Chicago: Rand McNally, 1965. p. 1-47.

CHAFFEY, D. Global Social Media Research Summary 2017. Disponível em: $<$ http://www.smartinsights.com/social-media-marketing/social-mediastrategy/new-global-social-media-research/>. Acesso em: 18 out. 2017.

CHAIKEN, S. Communicator Physical Attractiveness and Persuation. Journal of Personality and Social Psychology, v. 37, n. 8, p. 1387-1397, 1979.

CHUA, T. H. H.; CHANG, L. Follow me and Like my Beautiful Selfies: Singapore Teenage Girls' Engagement in Self-Presentation and Peer Comparison on Social Media. Computers in Human Behavior, v. 55, p. 190-197, 2016.

CLAVIO, G.; BURCH, L. M.; FREDERICK, E. L. Networked Fandom : Applying Systems Theory to Sport Twitter Analysis Social-Network Analysis. International Journal of Sport Communication, n. 5, p. 522-538, 2012.

COHEN, J.; COLIN, S. Strong Is the New Skinny: How to Eat, Live, and Move to Maximize Your Power. Nova Iorque: Harmony, 2014.

COHEN, R. J. What a Qualitative Research Can Be. Psychology and Marketing, v. 16, n. 4, p. 351-358, 1999.

COLlinS, J.; HUSSEY, R. Pesquisa em Administração: Um Guia Prático para Alunos de Graduação e Pós-Graduação. 2 $2^{\mathrm{a}}$ ed. Bookman, 2005.

COOPER, P. A la Poursuite de l'Excellence: L'Évolution et l'Avenir de la Recherche Qualitative. Revue Française du Marketing, v. 3, n. 5, p. 5-26, 2008.

CORDEIRO, M. O Valor do Corpo na Construção da Identidade. Revista de Estudos da Comunicação, v. 12, n. 27, p. 19-26, 2011.

COURNEYA, K. S. et al. Social Support and the Theory of Planned Behavior in the Exercise Domain. America Journal of Heatlh and Behaviour, v. 24, n. 4, p. 300-308, 2000.

COVA, B.; COVA, V. Tribal Marketing: The Tribalisation of Society and its Impact on the Conduct of Marketing. European Journal of Marketing, v. 36, n. 5/6, p. 595-620, 2002.

COYNE, S. M.; PADILLA-WALKER, L. M.; HOWARD, E. Emerging in a Digital World: A Decade Review of Media Use, Effects, and Gratifications. Emerging Adulthood, v. 1, n. 2, p. 125-137, 2013.

CUSHING, A. L. Possessions and Self Extension in Digital Environments: Implications for Maintaining Personal Information. University of North Carolina at Chapel Hill, 2012. 
DARLOW, S. D.; XU, X. The Influence of Close Others' Exercise Habits and Perceived Social Support on Exercise. Psychology of Sport and Exercise, v. 12, n. 5, p. 575-578, 2011.

DAWSON, M. C. CrossFit: Fitness Cult or Reinventive Institution? International Review for the Sociology of Sport, v. 52, n. 3, p. 361-379, 2017.

DIMAGGIO, P. J.; POWELL, W. The Iron Cage Revisited: Institutional Isomorphism and Collective Rationality in Organizational Fields. American Sociological Review, v. 48, n. 2, p. 147-160, 1983.

DISHMAN, R.; SALLIS, J. F.; ORENSTEIN, D. R. The Determinants of Physical Activity and Exercise. Public Health Reports, v. 100, n. 2, p. 158-171, 1985.

DOWNE-WAMBOLDT, B. Content Analysis: Method, Applications and Issues. Health Care for Women International, v. 13, n. 3, p. 313-321, 1992.

DWORKIN, S. L.; WACHS, F. L. Body Panic: Gender, Health, and the Selling of Fitness. NYU Press, 2009.

EAGLEMAN, A. N. Acceptance, Motivations, and Usage of Social Media as a Marketing Communications Tool Amongst Employees of Sport National Governing Bodies. Sport Management Review, v. 16, n. 4, p. 488-497, 2013.

EAGLY, A. H.; WOOD, W.; CHAIKEN, S. Causal Inferences about Communicators and Their Effect on Opinion Change. Journal of Personality and Social Psychology, v. 36, n. 4, p. 424-435, 1978.

FARDOULY, J. et al. Social Comparisons on Social Media: The Impact of Facebook on Young Women's Body Image Concerns and Mood. Body Image, v. 13, p. 38-45, 2015.

FESTINGER, L. A Theory of Social Comparison Processes. Human Relations, v. 7, n. 2, p. 117-140, 1954.

FILO, K.; LOCK, D.; KARG, A. J. Sport and Social Media Research: A Review. Sport Management Review, v. 18, n. 2, p. 166-181, 2015.

FOSSÁ, M. I. T. Proposição de um Constructo para Análise da Cultura de Devoção nas Empresas Familiares e Visionárias - uma Definição Teórica e Operacional. Universidade Federal do Rio Grande do Sul, 2003.

FOX, J.; ROONEY, M. C. The Dark Triad and Trait Self-Objectification as Predictors of Men's Use and Self-Presentation Behaviors on Social Networking Sites. Personality and Individual Differences, v. 76, p. 161-165, 2015.

FOX, J.; VENDEMIA, M. A. Selective Self-Presentation and Social Comparison Through Photographs on Social Networking Sites. Cyberpsychology, Behavior, and Social Networking, v. 19, n. 10, p. 593-600, 2016.

FRANCO, M. L. P. B. Análise de Conteúdo. $3^{\text {a }}$ ed. Brasília: Líber Livro, 2008. 
FREDRICKSON, B. L.; ROBERTS, T.-A. Objectification Theory: Toward Understanding Wome's Live Expierences and Mental Health Risks. Psychology of Women Quarterly, v. 21, n. March, p. 173-206, 1997.

GENTILE, D. Pathological Video Game Use among Youth 8 to 18: A National Study. Psychological Science, v. May, n. 5, p. 594-602, 2009.

GENTILE, D. A.; COYNE, S. M.; BRICOLO, F. Pathological Technology Addictions: A Review os The Literature and a Diagnosis Paradigm. In: The Oxford Handbook of Media Psychology. Oxford University Press, 2013. p. 382-402.

GIDDENS, A. Modernity and Self-Identity - Self and Society in the Late Modern Age. Stanford: Stanford University Press, 1991.

GIL, A. C. Métodos e Técnicas de Pesquisa Social. $6^{\text {a }}$ ed. São Paulo: Atlas, 2008.

GLASSMAN, G. CrossFit - Foundations. CrossFit Journal, p. 1-8, 2002.

GLASSMAN, G. What is CrossFit? CrossFit Journal, v. 19, p. 1-7, 2004.

GLASSMAN, G. Community Support: Interview with Fast Company Magazine. The CrossFit Journal, 2011.

GOETHALS, G. R.; NELSON, R. E. Similarity in the Influence Process: The Belief-Value Distinction. Journal of Personality and Social Psychology, v. 25, n. 1, p. 117-122, 1973.

GOFFMAN, E. The Presentation of Self in Everyday Life. University of Edinburgh, 1956.

GOFFMAN, E. Asylums: Essays on the Social Situation of Mental Patients and Other Inmates. $1^{\text {a }}$ ed. Anchor Books / Doubleday, 1961.

GOFFMAN, E. The Interaction Order: American Sociological Association. American Sociological Review, v. 48, n. 1, p. 1-17, 1983.

GOLDSTEIN, M. S. The Health Movement: Promoting Fitness in America. Nova Iorque: Twayne Publishers, 1992.

GONZALES, A. L.; HANCOCK, J. T. Mirror, Mirror on my Facebook Wall: Effects of Exposure to Facebook on Self-Esteem. Cyberpsychology, Behavior, and Social Networking, v. 14, n. 1-2, p. 79-83, 2011.

GOULDING, C.; SHANKAR, A.; ELLIOT, R. Dance Clubs, Rave and the Consumer Experience: an Exploratory Study of a Subcultural Phenomenon. In: European Advances in Consumer Research. Provo, UT: Association for Consumer Research, 2001. p. 203-208.

GRAFFAM, G. A Posthuman Perspective on Virtual Worlds. In: Human no More: Digital Subjectivities, Unhuman Subjects, and the end of Anthropology. Boulder: University Press of Colorado, 2012. p. 131-146. 
GREENWOOD, D. N.; LONG, C. R. Mood Specific Media Use and Emotion Regulation: Patterns and Individual Differences. Personality and Individual Differences, v. 46, n. 5-6, p. 616-621, 2009.

GRÖNROOS, C. The relationship marketing process: Communication, interaction, dialogue, value. Journal of Business and Industrial Marketing, v. 19, n. 2, p. 99113, 2004.

HAFERKAMP, N. et al. Men Are from Mars, Women Are from Venus? Examining Gender Differences in Self-Presentation on Social Networking Sites. Cyberpsychology, Behavior, and Social Networking, v. 15, n. 2, p. 91-98, 2012.

HAMBRICK, M. E.; FREDERICK, E. L.; SANDERSON, J. From Yellow to Blue. Communication \& Sport, v. 3, n. 2, p. 196-218, 2015.

HARRISON, T. M.; BARTHEL, B. Wielding New Media in Web 2.0: Exploring the History of Engagement with the Collaborative Construction of Media Products. New Media and Society, v. 11, n. 1-2, p. 155-178, 2009.

HASS, R. G. Effects of Source Characteristics on Cognitive Responses and Persuasion. In: Cognitive responses in persuasion. Hillsdale: Lawrence Erlbaum, 1981. p. 141-172.

HATCH, M. J.; SCHULTZ, M. Toward a Theory of Brand Co-Creation with Implications for Brand Governance. Journal of Brand Management, v. 17, n. 8, p. 590-604, 2010.

HEIDEGGER, M. Being and Time. $1^{a}$ ed. Nova Iorque: Harper and Row, 1962.

HERZ, J. C. Learning to Breathe Fire: The Rise of Crossfit and the Primal Future of Fitness. United States of America: Three Rivers Press, 2014.

HODDER, I. Entangled: An Archaeology of the Relationships Between Humans and Things. Chichester: Wiley-Blackwell, 2012.

HOGG, M. A.; TERRY, D. J. Social Identity and Self- Categorization Processes in Organizational Contexts. Academy of Management Review, v. 25, n. 1, p. 121140, 2000.

HORTON, D.; WOHL, R. Mass Communication and Para-Social Interaction. Psychiatry, v. 19, n. 3, p. 215-229, 1956.

HU, Y.; MANIKONDA, L.; KAMBHAMPATI, S. What Ee Instagram : a First Analysis of Instagram Photo Content and User Types. Proceedings of the Eight International AAAI Conference on Weblogs and Social Media, p. 595-598, 2014.

HUM, N. J. et al. A Picture is Worth a Thousand Words: A Content Analysis of Facebook Profile Photographs. Computers in Human Behavior, v. 27, n. 5, p. 1828-1833, 2011.

JAMES, W. The Principles of Psychology. New York: Henry Holt, 1890. v. 1 
JAMES, W. Psychology. Greenwich, CT: Fawcett, 1963.

KAPLAN, A. M.; HAENLEIN, M. Users of the World, Unite! The Challenges and Opportunities of Social Media. Business Horizons, v. 53, n. 1, p. 59-68, 2010.

KATZ, LM.; SHARPIRO, C. Network Externalities, Compettion and Compatibility. The American Economic Review, v. 75, n. 3, p. 424-440, 1985.

KEMP, S. Digital in 2017: Global Overview. Disponível em: <https://wearesocial.com/special-reports/digital-in-2017-global-overview>.

Acesso em: 21 jun. 2017.

KIETZMANN, J. H. et al. Social media? Get serious! Understanding the functional building blocks of social media. Business Horizons, v. 54, n. 3, p. 241-251, 2011.

KIM, H.; PAPACHARISSI, Z. Cross-cultural Differences in Online SelfPresentation: A Content Analysis of Personal Korean and US Home Pages. Asian Journal of Communication, v. 13, n. 1, p. 117-136, 2003.

KINDBERG, T. et al. An In-Depth Study of Camera Phone Use. 2005.

KLEIN, M. H. et al. A Comparative Outcome Study of Group Psychotherapy vs. Exercise Treatments for Depression. International Journal of Mental Health, v. 13, n. 3-4, p. 148-176, 1985.

KLEINA, N. A História da Internet: a Década de 1990 [infográfico]. Disponível em: <https://www.tecmundo.com.br/infografico/10054-a-historia-da-internet-adecada-de-1990-infografico-.htm>. Acesso em: 18 out. 2017.

KNOPLOCH, C.; FURTADO, T. Crossfit é Impulsionado por Promessa de Resultados Rápidos e já Conta com mais de 70 Espaços no Rio. Disponível em: $<$ https://blogs.oglobo.globo.com/pulso/post/crossfit-e-impulsionado-por-

promessa-de-resultados-rapidos-e-ja-conta-com-mais-de-70-espacos-no-rio.html $>$. Acesso em: 27 dez. 2017.

KOZINETS, R. V. E-Tribalized Marketing? The Strategic Implications of Virtual Communities of Consumption. European Management Journal, v. 17, n. 3, p. 252-264, 1999.

KRIPPENDORFF, K. Content Analysis: An Introduction to Its Methodology. 2. ed. Thousand Oaks: Sage Publications, 2004.

LALICH, J.; LANGONE, M. Characteristics associated with cultic groups. In: Take Back Your Life: Recovering from Cults and Abusive Relationships. Berkeley: Bay Tree Publishing, 2006. p. 327-328.

LANG, K.; LANG, G. E. Collective Dynamics. Nova Iorque: Crowell, 1961.

LATANE, B. The psychology of social impact. American Psychologist, v. 36, n. 4, p. 343-356, 1981. 
LEBEL, K.; DANYLCHUK, K. How Tweet It Is: A Gendered Analysis of Professional Tennis Players' Self-Presentation on Twitter. International Journal of Sport Communication, v. 5, n. 4, p. 461-480, 2012.

LIPPITT, R.; POLANSKY, N.; ROSEN, S. The Dynamics of Power: A Field Study of Social Influence in Groups of Children. Human Relations, v. 5, p. 37-64, 1952.

LOCK, D. et al. Exploring the Development of Team Identification. Journal of Sport Management, v. 26, n. 4, p. 283-294, 2012.

LONSDALE, A. J.; NORTH, A. C. Why do We Listen to Music? A Uses and Gratifications Analysis. British Journal of Psychology, v. 102, n. 1, p. 108-134, 2011.

LUNDEN, I. Instagram Is The Fastest-Growing Social Site Globally, Mobile Devices Rule Over PCs For Access. Disponível em: $<$ https://techcrunch.com/2014/01/21/instagram-is-the-fastest-growing-social-siteglobally-mobile-devices-rule-over-pcs-for-social-access/>. Acesso em: 20 nov. 2017.

LURIE, A. The Language of Clothes. $1^{\text {a }}$ ed. Nova Iorque: Random House, 1981.

MACEDO, L. S. R.; SILVEIRA, A. C. Self: Um Conceito em Desenvolvimento. Paideia, v. 22, n. 52, p. 281-289, 2012.

MADWAY, G. Twitter Remakes Website, Adds New Features. Disponível em: $<$ http://www.reuters.com/article/twitter/update-2-twitter-remakes-website-addsnew-features-idUSN1411135520100915>. Acesso em: 18 out. 2017.

MAFFESOLI, M. The Time of the Tribes. Londres: Sage, 1996.

MAGUIRE, J. S. Fit for Consumption: Sociology and the Business of Fitness. $1^{\mathrm{a}}$ ed. Routledge, 2007.

MAlHOtRA, N. Pesquisa de Marketing: Uma Orientação Aplicada. $6^{\text {a }}$ ed. Porto Alegre: Bookman, 2011.

MANAGO, A. M. et al. Self-Presentation and Gender on MySpace. Journal of Applied Developmental Psychology, v. 29, n. 6, p. 446-458, 2008.

MARKULA, P. Firm but Shapely, Fit but Sexy, Strong but Thin: The Postmodern Aerobicizing Female Bodies. Sociology of Sport Journal, v. 12, p. 424-453, 1995.

MARQUES, J. R. Definição de Self. Disponível em: <http://www.jrmcoaching.com.br/blog/definicao-de-self/>. Acesso em: 24 jun. 2017.

MARSDEN, P. V.; FRIEDKIN, N. E. Network Studies of Social Influence. Sociological Methods \& Research, v. 22, n. 1, p. 127-151, 1993.

MARSHALL, P. D. The Promotion and Presentation of the Self: Celebrity as Marker of Presentational Media. Celebrity Studies, v. 1, n. 1, p. 35-48, 2010. 
MAY, R.; YALOM, I. Existential Psychotherapy. In: Current Psychotherapies. Itasca: F.E. Peacock, 1984. p. 354-391.

MCAULEY, E.; RUDOLPH, D. Physical Activity , Aging, and Psychological. Journal of Aging and Physical Activity, v. 3, n. 1, p. 67-96, 1995.

MCCARTHY, E. D. Towards a Sociology of the Physical World: George Herbert Mead on Physical Objects. Studies in Symbolic Interaction: A Research Annual, p. 105-121, 1984.

MCCARTHY, E. D. The Social Construction of Emotions: New Directions from Culture Theory. Social Perspectives on Emotion, v. 2, n. 24, p. 267-279, 1994.

MCCARTHY, E. D. The Emotions: Senses of the Modern Self. Sociology Faculty Publications, Paper 12, p. 30-49, 2002.

MCCARTHY, J. et al. Managing brand presence through social media: The case of UK football clubs. Internet Research, v. 24, n. 2, p. 181-204, 2014.

MCCLELLAND, D. C. Personality. p. 654, 1951.

MCGUIRE, R. T.; COOK, D. L. The Influence of Others and the Decision to Participate in Youth Sports. Journal of Sport Behavior, v. 6, p. 9-15, 1983.

MCKENZIE, S. Getting Physical: The Rise Of Fitness Culture In America. Lawrence: University Press of Kansas, 2013.

MEHDIZADEH, S. Self-Presentation 2.0: Narcissism and Self-Esteem on Facebook. Cyberpsychology, Behavior, and Social Networking, v. 13, n. 4, p. 357-364, 2010.

MILLINGTON, B. Smartphone Apps and the Mobile Privatization of Health and Fitness. Critical Studies in Media Communication, v. 31, n. 5, p. 479-493, 2014.

MINAYO, M. O Desafio do Conhecimento. Hucitec, 1993.

MOON, A.; SADAM, R. Twitter Posts Strong User Growth, Shares Soar. Disponível em: <http://www.reuters.com/article/us-twitter-results/twitter-postsstrong-user-growth-shares-soar-idUSKBN17S1E7>. Acesso em: 18 out. 2017.

MURPHY, T. J. Inside the Box: How CrossFit Shredded the Rules, Stripped Down the Gym and Rebuilt My Body. VeloPress, 2012.

NAAMAN, M.; BOASE, J.; LAI, C.-H. Is it Really About Me? Proceedings of the 2010 ACM Conference on Computer Supported Cooperative Work, p. 189, 2010.

NOWAK, A.; SZAMREJ, J.; LATANÉ, B. From Private Attitude to Public Opinion: A Dynamic Theory of Social Impact. Psychological Review, v. 97, n. 3, p. 362-376, 1990. 
O'REILLY, T. What Is Web 2.0: Design Patterns and Business Models for the Next Generation of Software. International Journal of Digital Economics, n. 65, p. 17-37, 2007.

ONG, E. Y. L. et al. Narcissism, extraversion and adolescents' self-presentation on Facebook. Personality and Individual Differences, v. 50, n. 2, p. 180-185, 2011.

PADILHA, A.; CABRAL, P. Significado de Identidade. Disponível em: <https://www.significados.com.br/sobre/>. Acesso em: 24 jun. 2017.

PADILLA-WALKER, L. M. et al. More Than a Just a Game: Video Game and Internet use During Emerging Adulthood. Journal of Youth and Adolescence, v. 39, n. 2, p. 103-113, 2010.

PARK, R. E.; BURGESS, E. W. Introduction to the Science of Sociology. $2^{\mathrm{a}}$ ed. Chicago: University of Chicago Press, 1924.

PATTON, M. Q. Qualitative Research \& Evaluation Methods. $3^{\text {a }}$ ed. Thousand Oaks: Sage Publications, 2002.

PETRESCU, M.; LAUER, B. Qualitative Marketing Research: The State of Journal Publications. Qualitative Report, v. 22, n. 9, p. 2248-2287, 2017.

POLLIO, H. R. Behavior and Existence. Monterey: Brooks/Cole, 1982.

POWERS, D.; GREENWELL, D. M. Branded Fitness: Exercise and Promotional Culture. Journal of Consumer Culture, v. 17, n. 3, p. 523-541, 2016.

RENTFROW, P. J.; GOSLING, S. D. The Do Re Mi's of Everyday Life: The Structure and Personality Crrelates of Music Preferences. Journal of Personality and Social Psychology, v. 84, n. 6, p. 1236-1256, 2003.

RICHTER, F. Competition Leaves Twitter in the Dust. Disponível em: <https://www.statista.com/chart/5358/twitters-user-growth-in-perspective/>.

Acesso em: 25 out. 2017.

RINKUNAS, S. Strong is the new sexy. 2011.

ROBINSON, T. T.; CARRON, A. V. Personal and Situational Factors Associated With Dropping Out versus Maintaining Participation in Competitive Sport. Journal of Sport Psychology, v. 4, n. 4, p. 364-378, 1982.

ROCHBERG-HALTON, E. Object Relations, Role Models, and Cultivation of the Self. Environment and Behavior, v. 16, n. 3, p. 335-368, 1984.

ROOK, D. W. Body Cathexis and Market Segmentation. In: The Psychology of Fashion. $1^{\text {a }}$ ed. Lexington Books, 1985. p. 233-242.

RUZGAR, N. S. A Research on the Purpose of Internet Usage and Learning via Internet. The Turkish Online Journal of Educational Technology, v. 4, p. 27$32,2005$. 
SAMARA, B. S.; BARROS, C. J. Pesquisa de Marketing: Conceito e Metodologia. $4^{\text {a }}$ ed. São Paulo: Pearson, 2006.

SANDERSON, J.; HAMBRICK, M. E. Covering the Scandal in 140 Characters : A Case Study of Twitter's Role in Coverage of the Penn State Saga. International Journal of Sport Communication, v. 5, n. 3, p. 384-402, 2012.

SARTRE, J. P. O Ser e o Nada: Ensaio de Ontologia Fenomenologica. 15. ed. Petropolis, RJ: Vozes, 2005.

SASSATELLI, R. Fitness Culture: Gyms and the Commercialisation of Discipline and Fun. Palgrave Macmillan, 2010.

SATURNO, A. Instagram Chega a 700 Milhões de Usuários e tem Crescimento Histórico. Disponível em: <https://canaltech.com.br/redes-sociais/instagramchega-a-700-milhoes-de-usuarios-e-tem-crescimento-historico-92798/>. Acesso em: 25 out. 2017.

SCHAU, H. J.; GILLY, M. C. We are What We Post? Self- Presentation in Personal Web Space. Journal of Consumer Research, v. 30, n. 3, p. 385-404, 2003.

SCOTT, S. Revisiting the Total Institution: Performative Regulation in the Reinventive Institution. Sociology, v. 44, n. 2, p. 213-231, 2010.

SCOTT, S. Contradictions of Capitalism in Health and Fitness Leisure. In: Handbook on the Economics of Leisure. p. 153. 2011.

SEIDMAN, G. Expressing the "true Self" on Facebook. Computers in Human Behavior, v. 31, n. 1, p. 367-372, 2014.

SHETH, J. N.; SOLOMON, M. R. Extending the Extended Self in the Digital World. The Journal of Marketing Theory and Practice, v. 22, n. 2, p. 123-132, 2014.

SHILBURY, D. et al. Strategic Sport Marketing. $4^{\mathrm{a}}$ ed. Sidney: Allen and Unwin, 2014.

SHILLING, C. The body and social theory. $3^{\mathrm{a}}$ ed. SAGE Publications Ltd, 2012.

SHIN, Y. et al. Selfie and Self: The Effect of Selfies on Self-Esteem and Social Sensitivity. Personality and Individual Differences, v. 111, p. 139-145, 2017.

SIDDIQUI, S.; TURLEY, D. Extending the Self in a Virtual World. Advances in Consumer Research, v. 33, p. 647-648, 2006.

SILVERMANN, D. Interpreting Qualitative Data: Methods for Analysing Talk, Text and Interaction. Sage, 1993.

SIMMEL, G. Fashion. American Journal of Sociology, v. 62, n. 6, p. 541-558, 1957. 
SMITH, L. R.; SANDERSON, J. I'm Going to Instagram It! An Analysis of Athlete Self-Presentation on Instagram. Journal of Broadcasting and Electronic Media, v. 59, n. 2, p. 342-358, 2015.

SONTAG, S. Olhando o Sofrimento dos Outros. Quetzal Editores, 2015.

SORAPURE, M. Screening Moments, Scrolling Lives: Diary Writing on the Web. Biography, v. 26, n. 1, p. 1-23, 2003.

SPREY, J. W. C. et al. An Epidemiological Profile of CrossFit Athletes in Brazil. Orthopaedic Journal of Sports Medicine, v. 4, n. 8, p. 1-8, 2016.

STEFANONE, M. A.; LACKAFF, D.; ROSEN, D. Contingencies of Self-Worth and Social-Networking-Site Behavior. Cyberpsychology, Behavior, and Social Networking, v. 14, n. 1-2, p. 41-49, 2011.

STEINFIELD, C.; ELLISON, N. B.; LAMPE, C. Social Capital, Self-Esteem, and Use of Online Social Network Sites: A Longitudinal Analysis. Journal of Applied Developmental Psychology, v. 29, n. 6, p. 434-445, 2008.

SUBRAHMANYAM, K. et al. Online and Offline Social Networks: Use of Social Networking Sites by Emerging Adults. Journal of Applied Developmental Psychology, v. 29, n. 6, p. 420-433, 2008.

SUNG, Y. et al. Why We Post Selfies: Understanding Motivations for Posting Pictures of Oneself. Personality and Individual Differences, v. 97, p. 260-265, 2016.

TAJFEL, H. Social Psychology of Intergroup Relations. Annual Review of Psychology, v. 33, n. 1, p. 1-39, 1982.

TAJFEL, H.; TURNER, J. An Integrative Theory of Intergroup Conflict: The Social Psychology of Intergroup Relations, 1979.

TAJFEL, H.; TURNER, J. C. The Social Identity Theory of Intergroup Behavior: Psychology of Intergroup Relations, 1986. Disponível em: <http://psycnet.apa.org/psycinfo/2004-13697-016>

THOMPSON, C. J.; HIRSCHMAN, E. C. Understanding the Socialized Body - a Poststructuralist Analysis of Consumers Self-Conceptions, Body Images, and SelfCare Practices. Journal of Consumer Research, v. 22, n. 2, p. 139-153, 1995.

THOMPSON, C. J.; HOLT, D. B. Communities and Consumption: Research on Consumer Strategies for Constructing Communal Relationships in a Postmodern World. Advances in Consumer Research, v. 23, ACR, Provo, UT, p. 204-205, 1996.

THOMPSON, C. J.; LOCANDER, W. B.; POLliO, H. R. Putting Consumer Experience Back into Consumer Research: The Philosophy and Method of Existential-Phenomenology. Journal of Consumer Research, v. 16, n. 2, p. 133, 1989. 
THOMPSON, C. J.; ÜSTÜNER, T. Women Skating on the Edge: Marketplace Performances as Ideological Edgework. Journal of Consumer Research, v. 42, n. 2, p. 235-265, 2015.

TOSUN, L. P. Motives for Facebook Use and Expressing "True Self" on the Internet. Computers in Human Behavior, v. 28, n. 4, p. 1510-1517, 2012.

TOZETTO, C. Instagram Alcança 700 Milhões de Usuários e Mira Realidade Aumentada. Disponível em: <http://link.estadao.com.br/noticias/culturadigital,instagram-alcanca-700-milhoes-de-usuarios-e-mira-realidadeaumentada,70001752112>. Acesso em: 25 out. 2017.

TUAN, Y. Space and Place: The Perspective of Experience. $1^{\text {a } e d . ~ U n i v e r s i t y ~ o f ~}$ Minnesota Press. 1978.

TURNER, J. C. Social Categorization and Self-Concept: A Social Cognitive Theory of Group Behavior. In: Advances in Group Process: Theory and Research. Connecticut: JAI Press, 1985. p. 77-121.

TWENGE, J. M. et al. Egos Inflating Over Time: A Cross-Temporal Meta-Analysis of the Narcissistic Personality Inventory. Journal of Personality, v. 76, n. 4, p. 875-902, 2008.

VALLE, R. S.; KING, M. An Introduction to Existential-Phenomenological Thought in Psychology. In: Existential-Phenomenological Alternatives for Psychology. Nova Iorque: Oxford University Press, 1978. p. 6-17.

VAN DIJCK, J. Digital photography: Communication, Identity, Memory. Visual Communication, v. 7, n. 1, p. 57-76, 2008.

VAN HOUSE, N. A. Collocated Photo Sharing, Story-telling, and the Performance of Self. Journal of Human Computer Studies, v. 67, n. 12, p. 1073-1086, 2009.

VILHENA, E. Origem da Palavra. Disponível em: <http://origemdapalavra.com.br/pergunta/identidade/>. Acesso em: 24 jun. 2017.

WASHINGTON, M.; ECONOMIDES, M. Strong is the New Sexy: Women, CrossFit, and the Postfeminist Ideal. Journal of Sport and Social Issues, v. 40, n. 2, p. 143-161, 2016.

WOOD, N. T.; SOLOMON, M. R. Virtual Social Identity and Consumer Behavior. $1^{\text {a }}$ ed. Armonk: Routledge, 2010.

WU, P. et al. State of Connectivity 2015: A Report on Global Internet AccessFacebook. Disponível em: $<$ https://fbnewsroomus.files.wordpress.com/2016/02/state-of-connectivity-20152016-02-21-final.pdf>. Acesso em: 24 jun. 2017.

WU, Y. C. J.; CHANG, W. H.; YUAN, C. H. Do Facebook Profile Pictures Reflect User's Personality? Computers in Human Behavior, v. 51, p. 880-889, 2015. 
YEE, N.; BAILENSON, J. N.; DUCHENEAUT, N. The Proteus Effect: Implications of Transformed Digital Self-Representation on Online and Offline Behavior. Communication Research, v. 36, n. 2, p. 285-312, 2009.

ZWIER, S. et al. Boundaries to the Articulation of Possible Selves Through Social Networking Sites: The Case of Facebook Profilers' Social Connectedness. Cyberpsychology, Behavior, and Social Networking, v. 14, n. 10, p. 571-576, 2011. 